\title{
Physical Properties
}

\section{of the Coexisting Phases}

\section{and Thermochemical Properties}

of the $\mathrm{H}_{2} \mathrm{O}$ Component

in Boiling $\mathrm{NaCl}$ Solutions

GEOLOGICAL SURVEY BULLETIN 1421 - A

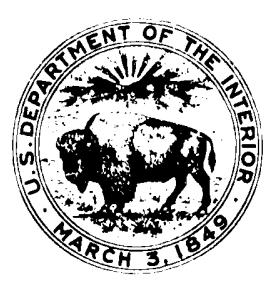




\section{Physical Properties of the Coexisting Phases and Thermochemical Properties of the $\mathrm{H}_{2} \mathrm{O}$ Component in Boiling $\mathrm{NaCl}$ Solutions}

$B y$ JOHN L. HAAS, JR.

PRELIMINARY STEAM TABLES FOR $\mathrm{NaCl}$ SOLUTIONS

GEOLOGICAL SURVEY B ULLETIN 1421 - A

Tables giving the temperature-vapor pressuredensity-specific volume relations for the coexisting liquid and gas and the partial molal volume, enthalpy, and entropy of the $\mathrm{H}_{2} \mathrm{O}$ component in the coexisting phases between $80^{\circ}$ and $325^{\circ} \mathrm{C}$ up to saturation in halite

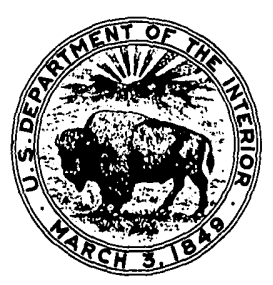




\title{
UNITED STATES DEPARTMENT OF THE INTERIOR \\ THOMAS S. KLEPPE, Secretary
}

\author{
GEOLOGICAL SURVEY
}

V. E. McKelvey, Director

Library of Congress Cataloging in Publication Data

\section{Haas, John L}

Physical properties of the coexisting phases and thermochemical properties of the $\mathrm{H}_{2} \mathrm{O}$ component in boiling $\mathrm{NaCl}$ solutions.

(Preliminary steam tables for $\mathrm{NaCl}$ solutions) (Geological survey bulletin; 1421-A)

Bibliography: p.

Supt. of Docs. no.: I $19.3: 1421-\mathrm{A}$

1. Thermochemistry - Tables, etc. 2. Solution (Chemistry)-Tables. 3. WaterThermal properties-Tables. I. Title. II. Series. III. Series: United States. Geological Survey. Bulletin; 1421-A.

QE75.B9 no. 1421-A [QD511.8] 557.3'08s $76-608098$ [541'.36'0212]

For sale by the Superintendent of Documents, U.S. Government Printing Office Washington, D.C. 20402

Stock Number 024-001-02904-9 


\section{CONTENTS}

\begin{tabular}{|c|c|}
\hline Abstract & $\begin{array}{r}\text { Page } \\
\text { A1 }\end{array}$ \\
\hline troduction & 1 \\
\hline nits, symbols, and constants & 2 \\
\hline Units and symbols used in tables and text & 2 \\
\hline Fundamental constants used in calculations & 4 \\
\hline Empirical constants used in the text and calculations & 4 \\
\hline hysical properties of the phases and thermochemical data for $\mathrm{H}_{2} \mathrm{O}$ & 5 \\
\hline Synopsis of the theoretical approach & 5 \\
\hline Vapor-pressure function & 6 \\
\hline Functions for the volumetric properties & 8 \\
\hline Density of the vapor-saturated solution & 8 \\
\hline Partial molal volume of $\mathrm{H}_{2} \mathrm{O}$ in the liquid & 10 \\
\hline Partial molal volume of $\mathrm{H}_{2} \mathrm{O}$ in the gas & 12 \\
\hline Enthalpy functions & 14 \\
\hline Partial molal enthalpy of $\mathrm{H}_{2} \mathrm{O}$ in the gas & 14 \\
\hline $\begin{array}{l}\text { Enthalpy difference between the gas and the liquid at con- } \\
\text { stant liquid composition }\end{array}$ & 14 \\
\hline $\begin{array}{l}\text { Partial molal enthalpy of } \mathrm{H}_{2} \mathrm{O} \text { in the liquid at constant com- } \\
\text { position }\end{array}$ & 15 \\
\hline Entropy functions & 15 \\
\hline Partial molal entropy of $\mathrm{H}_{2} \mathrm{O}$ in the gas & 15 \\
\hline Entropy difference between the gas and the liquid at constant & \\
\hline liauid comnosition & 16 \\
\hline $\begin{array}{l}\text { Partial molal entropy of } \mathrm{H}_{2} \mathrm{O} \text { in the liquid at constant com- } \\
\text { position }\end{array}$ & 17 \\
\hline Composition of the liquid at halite saturation & 18 \\
\hline The reference state for enthalpy and entropy & 18 \\
\hline les for $\mathrm{NaCl}$ solutions & 18 \\
\hline ferences cited & 19 \\
\hline
\end{tabular}

\section{ILLUSTRATIONS}

FIGURE 1. Schematic representation of the relation between $T_{x}$ and $T_{0}$

2. Vapor pressure of $\mathrm{NaCl}$ solutions from 0 wt percent to halite saturation at $80^{\circ}$ to $325^{\circ} \mathrm{C}$.

3. Density of the liquid phase for vapor-saturated $\mathrm{NaCl}$ solutions from 0 wt percent to halite saturation at $80^{\circ}$ to $325^{\circ} \mathrm{C}$

4. Specific volume of the liquid phase for vapor-saturated $\mathrm{NaCl}$ solutions from 0 wt percent to halite saturation at $80^{\circ}$ to $325^{\circ} \mathrm{C}$ 
Figure 5. The partial molal volume of $\mathrm{H}_{2} \mathrm{O}$ in the liquid phase for vapor-saturated $\mathrm{NaCl}$ solutions from 0 wt percent to halite saturation at $80^{\circ}$ to $325^{\circ} \mathrm{C}$

6. Specific volume of the gas phase for liquid-saturated $\mathrm{NaCl}$ solutions from 0 wt percent to halite saturation at $80^{\circ}$ to $325^{\circ} \mathrm{C}$

7. The partial molal enthalpy of $\mathrm{H}_{2} \mathrm{O}$ in the liquid and the gas for vapor-saturated $\mathrm{NaCl}$ solutions from 0 wt percent to halite saturation at $80^{\circ}$ to $325^{\circ} \mathrm{C}$

8. The partial molal entropy of $\mathrm{H}_{2} \mathrm{O}$ in the liquid and the gas for vapor-saturated $\mathrm{NaCl}$ solutions from 0 wt percent to halite saturation at $80^{\circ}$ to $325^{\circ} \mathrm{C}$

\section{TABLES}

$\bar{T}_{\text {ABLES }}$ 1-28. $\mathrm{NaCl}$ concentration:

1. $0.0000 \mathrm{~mol} / \mathrm{kg} \mathrm{H}_{2} \mathrm{O}, 0.00$ wt percent, $0.000 \mathrm{~mol}$ percent

2. $0.5000 \mathrm{~mol} / \mathrm{kg} \mathrm{H} \mathrm{H}_{2} \mathrm{O}, 2.84$ wt percent, $0.893 \mathrm{~mol}$ percent

3. $0.9006 \mathrm{~mol} / \mathrm{kg} \mathrm{H} \mathrm{H}_{2} \mathrm{O}, 5.00$ wt percent, $1.597 \mathrm{~mol}$ percent

4. $1.0000 \mathrm{~mol} / \mathrm{kg} \mathrm{H} \mathrm{H}_{2} \mathrm{O}, 5.52$ wt percent, $1.770 \mathrm{~mol}$ percent

5. $1.5000 \mathrm{~mol} / \mathrm{kg} \mathrm{H} \mathrm{H}_{2} \mathrm{O}, 8.06$ wt percent, $2.631 \mathrm{~mol}$ percent

6. $1.9012 \mathrm{~mol} / \mathrm{kg} \mathrm{H}_{2} \mathrm{O}, 10.00$ wt percent, $3.312 \mathrm{~mol}$ percent

7. $2.0000 \mathrm{~mol} / \mathrm{kg} \mathrm{H} \mathrm{H}_{2} \mathrm{O}, 10.47$ wt percent, $3.478 \mathrm{~mol}$ percent

8. $2.5000 \mathrm{~mol} / \mathrm{kg} \mathrm{H}_{2} \mathrm{O}, 12.75 \mathrm{wt}$ percent, $4.310 \mathrm{~mol}$ percent

9. $3.0000 \mathrm{~mol} / \mathrm{kg} \mathrm{H}_{2} \mathrm{O}, 14.92$ wt percent, $5.127 \mathrm{~mol}$ percent

10. $3.0195 \mathrm{~mol} / \mathrm{kg} \mathrm{H}_{2} \mathrm{O}, 15.00$ wt percent, $5.159 \mathrm{~mol}$ percent

11. $3.5000 \mathrm{~mol} / \mathrm{kg} \mathrm{H} \mathrm{H}_{2} \mathrm{O}, 16.98 \mathrm{wt}$ percent, $5.931 \mathrm{~mol}$ percent

12. $4.0000 \mathrm{~mol} / \mathrm{kg} \mathrm{H} \mathrm{H}_{2} \mathrm{O}, 18.95$ wt percent, $6.722 \mathrm{~mol}$ percent

13. $4.2777 \mathrm{~mol} / \mathrm{kg} \mathrm{H} \mathrm{O}, 20.00$ wt percent, $7.155 \mathrm{~mol}$ percent

14. $4.5000 \mathrm{~mol} / \mathrm{kg} \mathrm{H}_{2} \mathrm{O}, 20.82 \mathrm{wt}$ percent, $7.499 \mathrm{~mol}$ percent

15. $5.0000 \mathrm{~mol} / \mathrm{kg} \mathrm{H}_{2} \mathrm{O}, 22.61$ wt percent, $8.263 \mathrm{~mol}$ percent

16. $5.5000 \mathrm{~mol} / \mathrm{kg} \mathrm{H} \mathrm{H}_{2} \mathrm{O}, 24.32$ wt percent, $9.015 \mathrm{~mol}$ percent 
TABLES 1-28. NaCl concentration-Continued

Page

17. $5.7036 \mathrm{~mol} / \mathrm{kg} \mathrm{H} \mathrm{H}_{2}, 25.00 \mathrm{wt}$ percent, $9.318 \mathrm{~mol}$ percent

A56

18. $6.0000 \mathrm{~mol} / \mathrm{kg} \mathrm{H} \mathrm{H}_{2} \mathrm{O}, 25.96 \mathrm{wt}$ percent, $9.755 \mathrm{~mol}$ percent

19. $6.5000 \mathrm{~mol} / \mathrm{kg} \mathrm{H}_{2} \mathrm{O}, 27.53$ wt percent, 10.482 mol percent

20. $7.0000 \mathrm{~mol} / \mathrm{kg} \mathrm{H}_{2} \mathrm{O}, 29.03$ wt percent, 11.198 mol percent _...-......-.

21. $7.3332 \mathrm{~mol} / \mathrm{kg} \mathrm{H}_{2} \mathrm{O}, 30.00$ wt percent, 11.670

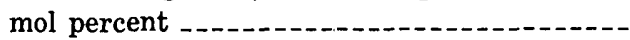

22. $7.5000 \mathrm{~mol} / \mathrm{kg} \mathrm{H}_{2} \mathrm{O}, 30.47$ wt percent, 11.903 mol percent -.............--

23. $8.0000 \mathrm{~mol} / \mathrm{kg} \mathrm{H}_{2} \mathrm{O}, 31.86$ wt percent, 12.597 mol percent ...............

24. $8.5000 \mathrm{~mol} / \mathrm{kg} \mathrm{H} \mathrm{H}_{2} \mathrm{O}, 33.19$ wt percent, 13.279 mol percent

25. $9.0000 \mathrm{~mol} / \mathrm{kg} \mathrm{H}_{2} \mathrm{O}, 34.47$ wt percent, 13.952 mol percent -.......... 67

26. $9.2135 \mathrm{~mol} / \mathrm{kg} \mathrm{H}_{2} \mathrm{O}, 35.00$ wt percent, 14.235 mol percent _........ 68

27. $9.5000 \mathrm{~mol} / \mathrm{kg} \mathrm{H}_{2} \mathrm{O}, 35.70$ wt percent, 14.613 mol percent

28. $10.0000 \mathrm{~mol} / \mathrm{kg} \mathrm{H}_{2} \mathrm{O}, 36.89$ wt percent, 15.265 mol percent

29. Halite-saturated $\mathrm{NaCl}$ solutions, concentrations in wt

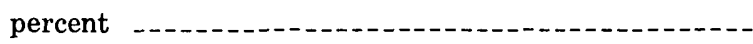

30. Halite-saturated $\mathrm{NaCl}$ solutions, concentrations in $\mathrm{mol} /$ kg $\mathrm{H}_{2} \mathrm{O}$ (molal) 


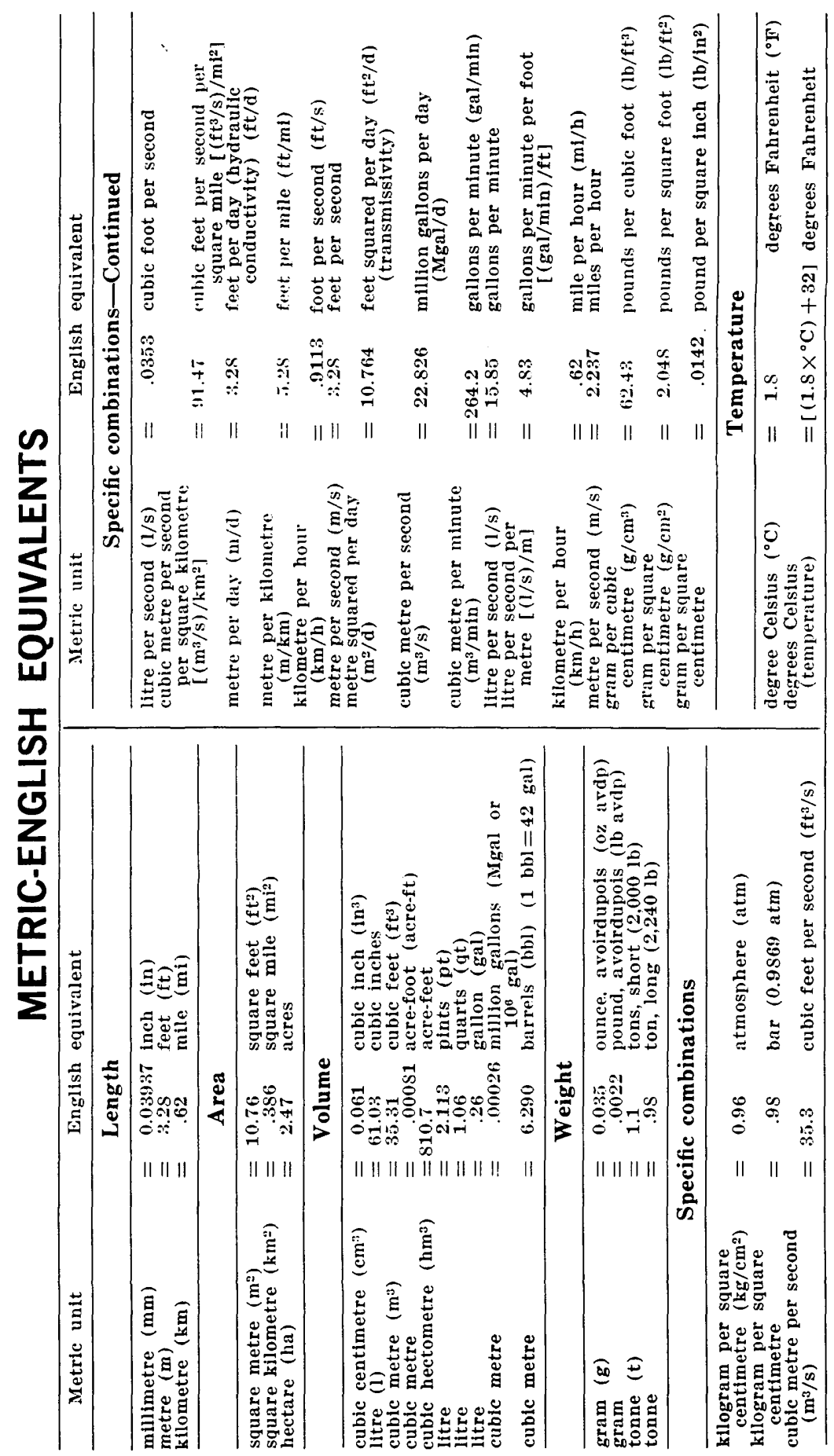




\title{
PHYSICAL PROPERTIES OF THE COEXISTING PHASES AND THERMOCHEMICAL PROPERTIES OF THE $\mathrm{H}_{2} \mathrm{O}$ COMPONENT IN BOILING NaCl SOLUTIONS
}

\author{
By John L. HaAs, JR.
}

\begin{abstract}
Preliminary steam tables that contain data on the physical properties of vapor-saturated aqueous sodium chloride solution and the coexisting gas are given for liquid concentrations between $0 \mathrm{~mol} \mathrm{NaCl} / \mathrm{kg} \mathrm{H}: \mathrm{O}$ and halite saturation at temperatures between $80^{\circ}$ and $325^{\circ} \mathrm{C}$. For the same conditions, the tables give the partial molal entropy, enthalpy, and volume of $\mathrm{H}_{2} \mathrm{O}$ in the phases. The tables were calculated from parametric equations of state.
\end{abstract}

\section{INTRODUCTION}

The tables assembled contain data for the following physical properties of aqueous, vapor-saturated sodium chloride solution and for the thermochemical properties of $\mathrm{H}_{2} \mathrm{O}$ in the solution:

vapor pressure of the liquid

density of the liquid

specific volume of the liquid

specific volume of the coexisting gas

partial molal volume of $\mathrm{H}_{2} \mathrm{O}$ in the liquid

partial molal entropy of $\mathrm{H}_{2} \mathrm{O}$ in the liquid

difference in the partial molal entropy of $\mathrm{H}_{2} \mathrm{O}$ between the gas and the liquid at constant composition of the liquid partial molal entropy of $\mathrm{H}_{2} \mathrm{O}$ in the coexisting gas partial molal enthalpy of $\mathrm{H}_{2} \mathrm{O}$ in the liquid difference in the partial molal enthalpy of $\mathrm{H}_{2} \mathrm{O}$ between the gas and the liquid at constant composition of the liquid partial molal enthalpy of $\mathrm{H}_{2} \mathrm{O}$ in the coexisting gas 
The values are tabulated for solution compositions from $0 \mathrm{~mol}$ $\mathrm{NaCl} / \mathrm{kg} \mathrm{H}_{2} \mathrm{O}$ to halite saturation at temperatures from $80^{\circ}$ to $325^{\circ} \mathrm{C}$. The assembled tables are essentially "steam tables" for vapor-saturated $\mathrm{H}_{2} \mathrm{O}-\mathrm{NaCl}$ solutions.

The tables presented here are preliminary. The functions upon which they are based represent a reasonably complete analysis of the available data through 1971. Final tables should include the energy content of the solution and the partial molal quantities for $\mathrm{NaCl}$ in the solution. Because there is an immediate need for the contained data, they have been made available in this preliminary form.

The tables are given as an aid to geochemical and engineering studies related to the geothermal energy program of the United States. They have been prepared in direct response to the suggestions of scientists and engineers at the Conference on Thermodynamics and National Energy Problems (National Academy of Sciences, 1974) and of an Ad Hoc Committee on Geothermal Chemistry (1974) convened by the U.S. Atomic Energy Commission. The research was made possible through the support of the U.S. Office of Saline Water (Agreements No. 14-30-3040) and the geothermal research program of the U.S. Geological Survey.

\section{UNITS, SYMBOLS, AND CONSTANTS}

\section{UNITS AND SYMBOLS USED IN TABLES AND TEXT}

The chosen units in the tables for measurements of temperature, pressure, specific volume, and density are ${ }^{\circ} \mathrm{C}$, bars, $\mathrm{cm}^{3} \mathrm{~g}^{-1}$, and $\mathrm{g}$ $\mathrm{cm}^{-3}$, respectively. These units are the same as those used in several widely referenced steam tables (Bain, 1964; Keenan and others, 1969). The partial molal entropy, enthalpy, and volume are given as $\mathrm{J} \mathrm{mol}^{-1} \mathrm{~K}^{-1}, \mathrm{~J} \mathrm{~mol}^{-1}$, and $\mathrm{cm}^{3} \mathrm{~mol}^{-1}$, respectively, because these are the units most used in thermodynamic calculations. Both weight percent and molal ( $\mathrm{mol} \mathrm{NaCl} / \mathrm{kg} \mathrm{H}_{2} \mathrm{O}$ ) scales for units of sodium chloride concentration are widely used in engineering and geochemical research. Both scales are used here to achieve maximum use of the tables.

The quantities, their symbols, and the associated units used in this text and in the tables are as follows: 


\begin{tabular}{|c|c|c|}
\hline Quantity & Symbol & Units \\
\hline density & $d$ & $\mathrm{~g} \mathrm{~cm}^{-3}$ \\
\hline specific enthalpy & $h$ & $J g^{-2}$ \\
\hline molal enthalpy & $H$ & $\mathrm{~J} \mathrm{\textrm {mol } ^ { - 1 }}$ \\
\hline $\begin{array}{l}\text { Masson's Rule slope in the } \\
\text { empirical equation for } \\
\text { apparent molal volume }\end{array}$ & $k$ & $\mathrm{~cm}^{3}\left(\mathrm{~kg} \mathrm{H}_{2} \mathrm{O}\right)^{1 / 2} /(\mathrm{mol} \mathrm{NaCl})^{3 / 2}$ \\
\hline mole fraction of $\mathrm{NaCl}$ & $N$ & $\mathrm{~mol} \mathrm{NaCl} /\left(\mathrm{mol} \mathrm{NaCl}+\mathrm{mol} \mathrm{H}_{2} \mathrm{O}\right)$ \\
\hline pressure & $p$ & $\operatorname{bar}\left(=1 \times 10^{5}\right.$ pascals $)$ \\
\hline molar gas constant & $R$ & $\mathrm{~J} \mathrm{~mol}{ }^{-1} \mathrm{~K}^{-1}$ \\
\hline specific entropy & $s$ & $\mathrm{~J}^{-1} \mathrm{~K}^{-1}$ \\
\hline molal entropy & $S$ & $\mathrm{~J} \mathrm{~mol}^{-1} \mathrm{~K}^{-1}$ \\
\hline temperature & $t$ & degrees Celsius, ${ }^{\circ} \mathrm{C}$ \\
\hline & $T$ & kelvins, $\mathrm{K}$ \\
\hline specific volume & $v$ & $\mathrm{~cm}^{3} \mathrm{~g}^{-1}$ \\
\hline molal volume & $V$ & $\mathrm{~cm}^{3} \mathrm{~mol}^{-1}$ \\
\hline molecular weight & $W$ & $\mathrm{~g} \mathrm{~mol}^{-1}$ \\
\hline concentration of $\mathrm{NaCl}$ in the & $x$ & $\mathrm{~mol} \mathrm{NaCl} / \mathrm{kg} \mathrm{H}_{2} \mathrm{O}$ (molal) \\
\hline liquid & $w$ & wt percent $\mathrm{NaCl}$ \\
\hline $\begin{array}{l}\text { apparent molal volume of } \mathrm{NaCl} \\
\text { in the liquid }\end{array}$ & $\phi$ & $\mathrm{cm}^{3} \mathrm{~mol}^{-1}$ \\
\hline $\begin{array}{l}\text { limiting apparent molal volume } \\
\text { of } \mathrm{NaCl} \text { in the liquid as } \\
\text { derived from Masson's } \\
\text { Rule }\end{array}$ & $\phi_{*}$ & $\mathrm{~cm}^{3} \mathrm{~mol}^{-1}$ \\
\hline
\end{tabular}

In the text and the tables the following superscripts are used:

$\begin{gathered}\text { Superscript } \\ \text { symbol } \\ G\end{gathered}$
The superscripted quantity is an attribute of the
gaseous phase.
The superscripted quantity is an attribute of the
liquid phase.
- (bar) The overscored quantity is a partial molal quantity
of the component indicated by the subscript, in the
solution.

In the text and the tables the following subscripts are used:

$\begin{gathered}\text { Subscript } \\ \text { symbol } \\ 1\end{gathered}$
2 The subscripted quantity is a partial quantity for the
component $\mathrm{H}_{2} \mathrm{O}$.
The subscripted quantity is a partial quantity for the
component $\mathrm{NaCl}$.
The subscripted quantity is an attribute of the pure
substance $\mathrm{H}_{2} \mathrm{O}$.
The subscripted quantity is an attribute of a solution
of constant but undefined composition in the system
NaCl- $\mathrm{H}_{2} \mathrm{O}$.
The subscripted quantity is an attribute of a solution
that is saturated in halite.
sat
The subscripted quantity is an attribute of the pure
substance $\mathrm{H}_{2} \mathrm{O}$ at the critical point where the prop-
erties of the liquid and the gas are identical.




\section{FUNDAMENTAL CONSTANTS USED IN CALCULATIONS}

The Committee on Data for Science and Technology (1973) of the International Council of Scientific Unions gives the molar gas constant $R$ as $(8.31441 \pm 0.00026) \mathrm{J} \mathrm{mol}^{-1} \mathrm{~K}^{-1}$.

The Commission on Atomic Weights (1972) gives the following atomic weights :

$\begin{array}{lr}\mathrm{H} & (1.0079 \pm 0.0001) \\ \mathrm{O} & (15.9994 \pm 0.0003) \mathrm{g} \mathrm{mol}^{-1} \\ \mathrm{Na} & (22.98977 \pm 0.00001) \\ \mathrm{g} \mathrm{mol} & \mathrm{g} \mathrm{mol}^{-1} \\ \mathrm{Cl} & (35.453 \pm 0.001) \mathrm{g} \mathrm{mol}^{-1}\end{array}$

From these atomic weights the molecular weights of the components are:

$$
\begin{array}{ll}
\mathrm{H}_{2} \mathrm{O} & W_{1}=(18.0152 \pm 0.0005) \mathrm{g} \mathrm{mol}^{-1} \\
\mathrm{NaCl} & W_{2}=(58.4428 \pm 0.0010) \mathrm{g} \mathrm{mol}^{-1}
\end{array}
$$

\section{EMPIRICAL CONSTANTS USED IN THE TEXT AND CALCULATIONS}

The following list gives the constants for the equations presented in the text. The equation numbers and the constants are as follows:

Equation 4 :

$$
\begin{aligned}
& a_{1}=5.93582 \times 10^{-6} \\
& a_{2}=-5.19386 \times 10^{-5} \\
& a_{3}=1.23156 \times 10^{-5}
\end{aligned}
$$

Equation 5 :

$$
\begin{aligned}
& b_{1}=1.15420 \times 10^{-6} \\
& b_{2}=1.41254 \times 10^{-7} \\
& b_{3}=-1.92476 \times 10^{-8} \\
& b_{4}=-1.70717 \times 10^{-9} \\
& b_{5}=1.05390 \times 10^{-10}
\end{aligned}
$$

Equation 6:

$$
\begin{aligned}
& e_{0}=12.50849 \\
& e_{1}=-4.616913 \times 10^{3} \\
& e_{2}=3.193455 \times 10^{-4} \\
& e_{3}=1.1965 \times 10^{-11} \\
& e_{4}=-1.013137 \times 10^{-2} \\
& e_{5}=-5.7148 \times 10^{-3} \\
& e_{6}=2.9370 \times 10^{5}
\end{aligned}
$$

Equation 9 :

$$
\begin{aligned}
& c_{0}=-167.219 \\
& c_{1}=448.55 \\
& c_{2}=-261.07
\end{aligned}
$$


Equation 10:

$$
\begin{aligned}
& c_{3}=-13.644 \\
& c_{4}=13.97 \\
& v_{c}=3.1975
\end{aligned}
$$

Equation 11:

$$
\begin{aligned}
& v_{c}=3.1975 \\
& c_{5}=-0.315154 \\
& c_{6}=-1.203374 \times 10^{-3} \\
& c_{7}=7.48908 \times 10^{-13} \\
& c_{8}=0.1342489 \\
& c_{9}=-3.946263 \times 10^{-3}
\end{aligned}
$$

Equation $17: a_{i j}$ are as follows :

\begin{tabular}{rrrr}
$j=0$ & $i=0$ & \multicolumn{1}{r}{$i=1$} & \multicolumn{1}{r}{$i=2$} \\
1 & 0.512004 & 0.611366 & 8.44104 \\
2 & -1.191807 & -3.258346 & 28.86344 \\
3 & 2.599832 & 6.393115 & -270.10366 \\
4 & -21.433083 & -6.447504 & 624.08835 \\
5 & 15.281761 & 3.202128 & -675.70455 \\
6 & -2.527165 & -0.514945 & 363.16788 \\
& -2.454047 & -0.120192 & -79.26405
\end{tabular}

\section{PHYSICAL PROPERTIES OF THE PHASES AND THERMOCHEMICAL DATA FOR $\mathrm{H}_{2} \mathrm{O}$}

\section{SYNOPSIS OF THE THEORETICAL APPROACH}

In previous research (Haas, 1970; 1971a, b), empirical expressions were presented for the vapor pressure and density of vapor-saturated sodium chloride solutions. Those results were combined with the expressions for the change of the pressure with temperature for a binary liquid of constant composition (Dalton and Barieau, 1968, p. 56, eq. 398) to prepare tables for the thermophysical properties of $\mathrm{H}_{2} \mathrm{O}$ in the coexisting liquid and gas.

$$
\left(\frac{\partial p}{\partial T}\right)_{x}=\frac{\left(1-N^{a}\right) \Delta \bar{S}_{1}+N^{a} \Delta \bar{S}_{2}}{\left(1-N^{G}\right) \Delta \bar{V}_{1}+N^{G} \Delta \overline{\bar{V}}_{2}}
$$

where the symbols are as defined in the previous section. The terms $\Delta \bar{S}, \Delta \bar{V}$, and $\Delta \bar{H}$ (eq 2) are the partial molal entropies, volumes, and enthalpies of vaporization of the components indicated by the subscripts. Because the coexisting liquid and gas are at equilibrium, the free-energy difference is zero and equation 1 may be restated:

$$
T\left(\frac{\partial p}{\partial T}\right)_{x}=\frac{\left(1-N^{a}\right) \Delta \bar{H}_{1}+N^{a} \Delta \bar{H}_{2}}{\left(1-N^{a}\right) \Delta \bar{V}_{1}+N^{a} \Delta \bar{V}_{2}}
$$


The partial molal entropy and partial molal enthalpy of $\mathrm{H}_{2} \mathrm{O}$ in the liquid can be obtained from pressure-temperature-composition and density-temperature-composition functions provided that the products $N^{G} \cdot \Delta \bar{S}_{2}, N^{G} \cdot \Delta \bar{H}_{2}$, and $N^{G} \cdot \Delta \bar{V}_{2}$ are small, and provided that the salt content of the vapor is nil. If the salt content of the vapor is nil, the properties of pure gaseous $\mathrm{H}_{2} \mathrm{O}$ at the temperature and pressure of the solution may be substituted for the partial molal quantities of $\mathrm{H}_{2} \mathrm{O}$ in the gas.

At $350^{\circ} \mathrm{C}$ and halite saturation, the vapor contains $8 \times 10^{-4} \mathrm{~mol}$ percent $\mathrm{NaCl}$ (Sourirajan and Kennedy, 1962). (Concentration data at $300^{\circ} \mathrm{C}$ are unavailable, but it would be less than $350^{\circ} \mathrm{C}$.) At $300^{\circ}$ and halite saturation, the enthalpy of vaporization of $\mathrm{NaCl}$ from the solution is estimated to be $15 \mathrm{~kJ} \mathrm{~mol}^{-1}$ and the product $N^{G} \cdot \Delta \bar{H}_{2}$ is less than $0.1 \mathrm{~J} \mathrm{~mol}^{-1}$ (estimated from an analysis of the data in Liu and Lindsay, 1971, and Sourirajan and Kennedy, 1962). The product $N^{G} \cdot \Delta \overline{S_{2}}$ is therefore less than $2 \times 10^{-4} \mathrm{~J} \mathrm{~mol}^{-1} \mathrm{~K}^{-1}$. The product $N^{G} \cdot \Delta \bar{V}_{2}$ could not be estimated.

Granting that the above products are small, equations 1 and 2 may be simplified:

$$
\begin{gathered}
\left(\frac{\partial p}{\partial T}\right)_{x}=\frac{\Delta \bar{S}_{1}}{\Delta \bar{V}_{1}}=\frac{\bar{S}_{1}^{G}-\bar{S}_{1}^{L}}{\bar{V}_{1}^{G}-\bar{V}_{1}^{L}} \\
T\left(\frac{\partial p}{\partial T}\right)_{x}=\frac{\Delta \bar{H}_{1}}{\Delta \bar{V}_{1}}=\frac{\bar{H}_{1}^{G}-\bar{H}_{1}^{L}}{\bar{V}_{1}^{G}-\bar{V}_{1}^{L}}
\end{gathered}
$$

In equations $1 \mathrm{a}$ and $2 \mathrm{a}$, the term $(\partial p / \partial T)_{x}$ may be evaluated from the functions for the vapor pressure of the solution; the terms $\bar{S}_{1}^{G}, \bar{H}_{1}^{G}$, and $\bar{V}_{1}^{G}$ from functions for the gaseous $\mathrm{H}_{2} \mathrm{O}$; and $\bar{V}_{1}^{L}$ from the function for the density of the vapor-saturated solution. The remaining terms $\bar{S}_{1}^{L}$ and $\bar{H}_{1}^{L}$ may be obtained by substitution of the described functions into equations $1 \mathrm{a}$ and $2 \mathrm{a}$, respectively, and solving the results.

\section{VAPOR-PRESSURE FUNCTION}

Haas $(1971 \mathrm{a}, \mathrm{b})$ used the reference substance technique as given by Othmer and $\mathrm{Yu}$ (1968) and further amplified by Othmer and Chen (1968) to correlate the vapor pressure of solutions of $\mathrm{NaCl}$ from 0 molal to halite saturation. From the Clapeyron equations for the vaporization of two liquids, Othmer and coworkers have shown that the temperature of the brine $T_{x}$ and the temperature 
of $\mathrm{H}_{2} \mathrm{O}$ liquid $T_{0}$ at the same pressure are related by the following equation:

$$
\left.\ln T_{0}=m \ln T_{x}+c \quad \text { (kelvins, } \mathrm{K}\right)
$$

Refer to figure 1 for a graphical description of the relation beween $T_{x}$ and $T_{0}$ at constant pressure. From $-11^{\circ}$ to $300^{\circ} \mathrm{C}$, where precise data are available, the empirical fit was made by setting $c=0$ and $m=\left(a+b T_{x}\right)^{-1}$. The terms $a$ and $b$ are concentration dependent polynomials of order 3 and 5 , respectively.

$$
\begin{aligned}
a=1.0 & +a_{1} x+a_{2} x^{2}+a_{3} x^{3} \\
b=0.0 & +b_{1} x+b_{2} x^{2}+b_{3} x^{3} \\
& +b_{4} x^{4}+b_{5} x^{5}
\end{aligned}
$$

The values of $a_{i}$ and $b_{i}$, revised from those given by Haas $(1971 \mathrm{a}, \mathrm{b})$ are given in the section entitled "Empirical constants

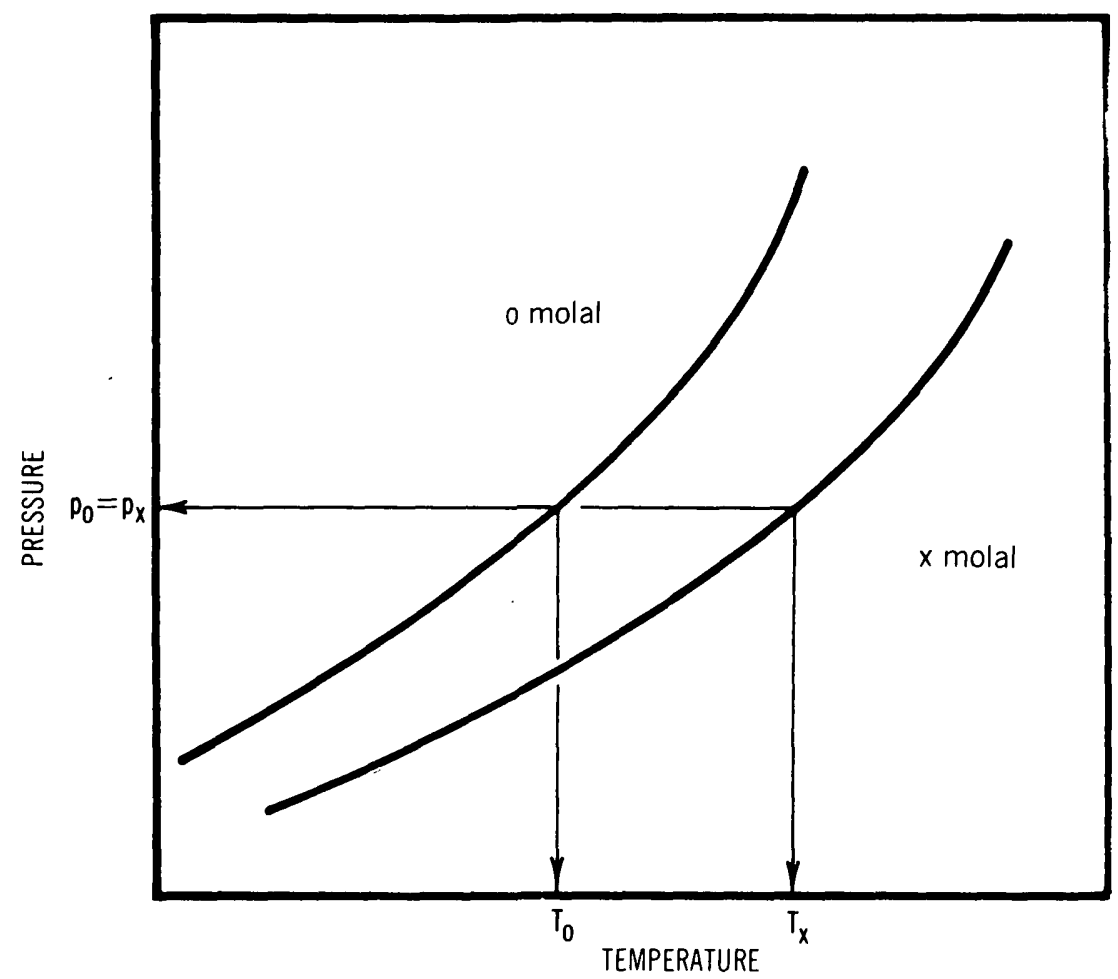

Figure 1.-Schematic representation of the relation between $T_{x}$ and $T_{0 .} T_{x}$ is the temperature of the brine, $x$ molal, and $T_{0}$ is the temperature of $\mathrm{H}_{2} \mathrm{O}$ liquid, 0 molal, at the same pressure $p_{0}=p_{x}$. The relation between $T_{x}$ and $T_{0}$ is given in the text. The vapor pressure of the brine is equal to the vapor pressure of $\mathrm{H}_{2} \mathrm{O}$ liquid at $T_{0}$. 
used in tables and text." The data from which the constants were obtained by least-squares regression are given in the following references. The range in temperature and composition that were covered by each data set is given in columns 2 and 3, respectively.

\begin{tabular}{|c|c|c|}
\hline Reference & $\begin{array}{c}\text { Temperature } \\
\left({ }^{\circ} \mathrm{C}\right)\end{array}$ & $\begin{array}{c}\text { Concentration } \\
(\text { molal })\end{array}$ \\
\hline Smith (1939) & 60 to 101 & 0.05 to 1.0 \\
\hline Smith and Hirtle (1939) & 61 to 105 & 1.5 to 4.0 \\
\hline Robinson and Stokes (1959) & 15 to 45 & 0.1 to 6.0 \\
\hline Gardner and others (1963) & 125 to 270 & 1.0 to 3.0 \\
\hline Lindsay and others (1968) & 125 to 300 & 0.1 to 1.0 \\
\hline Gardner (1969) & 140 to 265 & 0.5 to 1.0 \\
\hline Liu and Lindsay (1971) & 75 to 300 & $\begin{array}{l}3.7 \text { to halite } \\
\text { saturation }\end{array}$ \\
\hline Momicchioli and others (1970) & 0 to -11 & 0.02 to 3.1 \\
\hline $\begin{array}{l}\text { International Critical Tables Na- } \\
\text { tional Research Council, 1928) }\end{array}$ & 0 to 109 & $\begin{array}{l}0.0 \text { to halite } \\
\text { saturation }\end{array}$ \\
\hline
\end{tabular}

The vapor pressure of the brine at $T_{x}$ was then calculated from the vapor pressure of $\mathrm{H}_{2} \mathrm{O}$ liquid at the corresponding temperature $T_{0}$ by using equation 6 (modified from Bain, 1964).

$\ln p=e_{0}+\frac{e_{1}}{z}+\frac{e_{2} w}{z}+\left[10^{\left(c_{3} w^{2}\right)}-1.0\right]+e_{4} 10^{\left(c_{5} y^{1.22}\right)}$

where

$$
\begin{aligned}
& w=z^{2}-e_{6} \\
& y=647.27-T_{0} \\
& z=T_{0}+0.01
\end{aligned}
$$

The constants $e_{0}$ through $e_{6}$ are given in the section entitled "Empirical constants used in the text and calculations."

By using equations 3 through 6 , the standard error of estimate of the vapor pressure of sodium chloride solutions is calculated to be 0.32 percent of the observed pressure.

The vapor pressures of $\mathrm{NaCl}$ solutions from 0 wt percent to halite saturation are given in figure 2 . The contour interval is 5 wt percent $\mathrm{NaCl}$. The shaded part of the diagram is based on extrapolation of the functions given above.

\section{FUNCTIONS FOR THE VOLUMETRIC PROPERTIES}

\section{DENSITY OF THE VAPOR-SATURATED SOLUTION}

The density of the vapor-saturated sodium chloride solution is given by equations 7 through 10 below (Haas, 1970). 


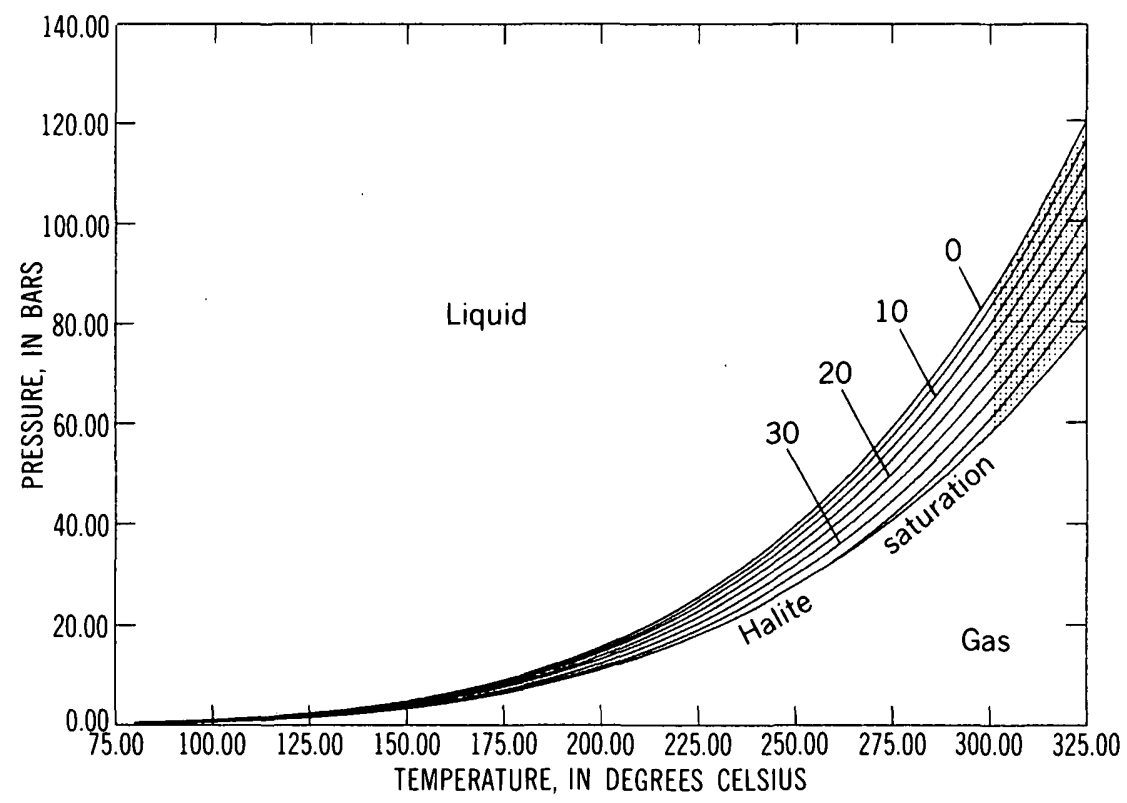

Figure 2.-Vapor pressure of $\mathrm{NaCl}$ solutions from 0 wt percent to halite saturation at $80^{\circ}$ to $325^{\circ} \mathrm{C}$. The contour interval is 5 wt percent $\mathrm{NaCl}$ contained in the liquid phase. The data in the shaded zone were calculated by extrapolating the functions given in the text.

$$
\begin{aligned}
& d=\frac{1000+x W_{2}}{1000 v_{0}+x \phi} \quad\left(\mathrm{g} \mathrm{cm}^{-3}\right) \\
& \phi=\phi_{*}+k x^{0.5} \quad\left(\mathrm{~cm}^{3} \mathrm{~mol}^{-1}\right) \\
& \phi_{*}=c_{0}+c_{1} v_{0}+c_{2} v_{0}^{2}\left(\mathrm{~cm}^{3} \mathrm{~mol}^{-1}\right)
\end{aligned}
$$

$k=\left(c_{3}+c_{4} v_{0}\right)\left[v_{0} /\left(v_{c}-v_{0}\right)\right]^{2}\left(\mathrm{~cm}^{3}\left(\mathrm{~kg} \mathrm{H}_{2} \mathrm{O}\right)^{1 / 2} /(\mathrm{mol} \mathrm{NaCl})^{3 / 2}\right)(10)$ where $d$ is the density, $W_{2}$ is the molecular weight of sodium chloride, $v_{0}$ is the vapor-saturated specific volume of liquid $\mathrm{H}_{2} \mathrm{O}$ at $T_{x}, v_{c}$ is the specific volume of $\mathrm{H}_{2} \mathrm{O}$ at the critical point, $\phi$ is the apparent molal volume of $\mathrm{NaCl}$ in the solution, and $\phi *$ is the limiting apparent molal volume of $\mathrm{NaCl}$ as the concentration in the liquid goes to 0 . The constants $c_{0}$ through $c_{4}$ are given in the section entitled "Empirical constants used in the text and calculations." As stated in the original article, no significance is to be attached to the forms of equations 9 and 10 except to say that they provide an adequate description of the apparent molal volume data.

The precision with which density may be calculated from these equations is $0.002 \mathrm{~g} \mathrm{~cm}^{-3}$. R. W. Potter II (oral commun., 1975) reported that the accuracy of the above equations may be as much 
as $0.006 \mathrm{~g} \mathrm{~cm}^{-3}$ because of experimental errors in the measured densities used in the regression. These errors are due to corrosion of the pressure vessels and introduction of $\mathrm{H}_{2}$ [aq] and metal ions into the liquid solution by reaction with the vessel. The errors would be most significant at low sodium chloride concentrations and relatively negligible near halite saturation.

The specific volume $v_{0}$ of $\mathrm{H}_{2} \mathrm{O}$ at $T_{x}$ is calculated from equation 11, which is modified from that given by Smith and Keyes (1934).

$$
v_{0} \frac{v_{c}+c_{5} \theta^{1 / 3}+c_{6} \theta+c^{7} \theta^{4}}{1.0+c_{8} \theta^{1 / 3}+c_{9} \theta}\left(\mathrm{cm}^{3} \mathrm{~g}^{-1}\right)
$$

where $\theta=647.27-T_{x}$. The constants $v_{c}$ and $c_{5}$ through $c_{9}$ are given in the section entitled "Units, symbols, and constants."

The density and specific volume of vapor-saturated $\mathrm{NaCl}$ liquids are given on figures 3 and 4 , respectively. The contour interval is 5 wt percent $\mathrm{NaCl}$.

\section{PARTIAL MOLAL VOLUME OF $\mathrm{H}_{2} \mathrm{O}$ IN THE LIQUID}

The partial molal volume of $\mathrm{H}_{2} \mathrm{O}$ in the binary liquid system is given by equation 12 :

$$
\bar{V}_{1}^{L}=V^{L}-N^{L} \frac{\partial V^{L}}{\partial N^{L}} \quad\left(\mathrm{~cm}^{3} \mathrm{~mol}^{-1}\right)
$$

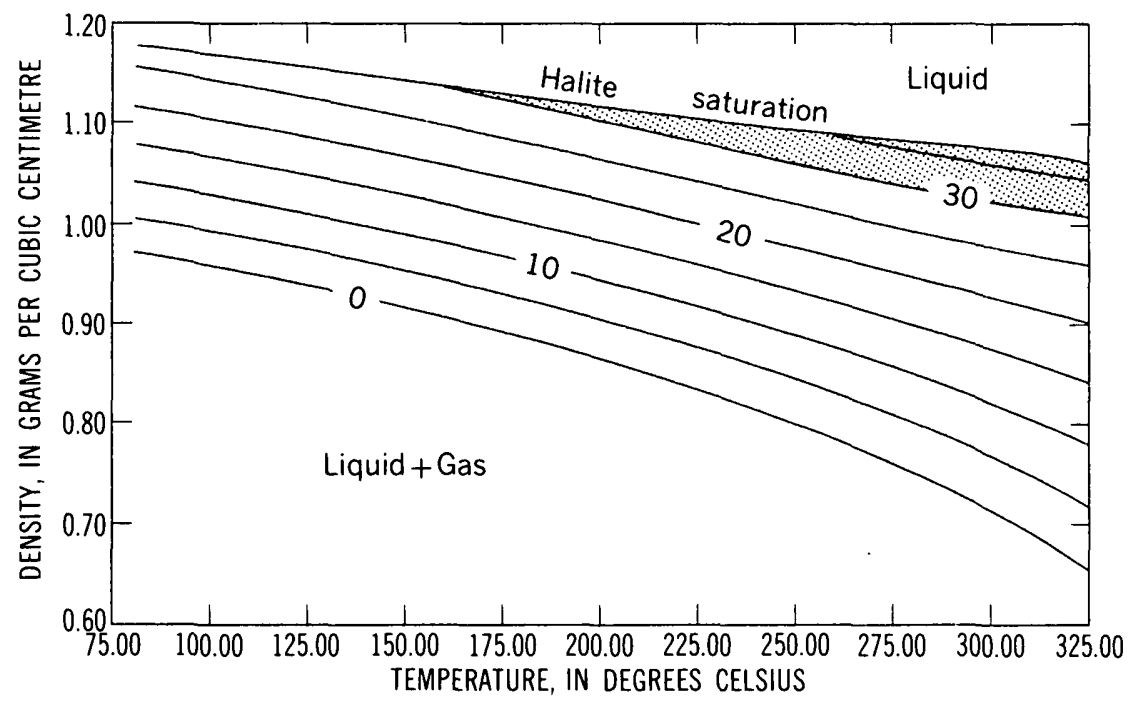

FIGURE 3.-Density of the liquid phase for vapor-saturated $\mathrm{NaCl}$ solutions from 0 wt percent to halite saturation at $80^{\circ}$ to $325^{\circ} \mathrm{C}$. Contour interval is 5 wt percent $\mathrm{NaCl}$. The shaded zone was calculated by extrapolating the functions given in the text. 


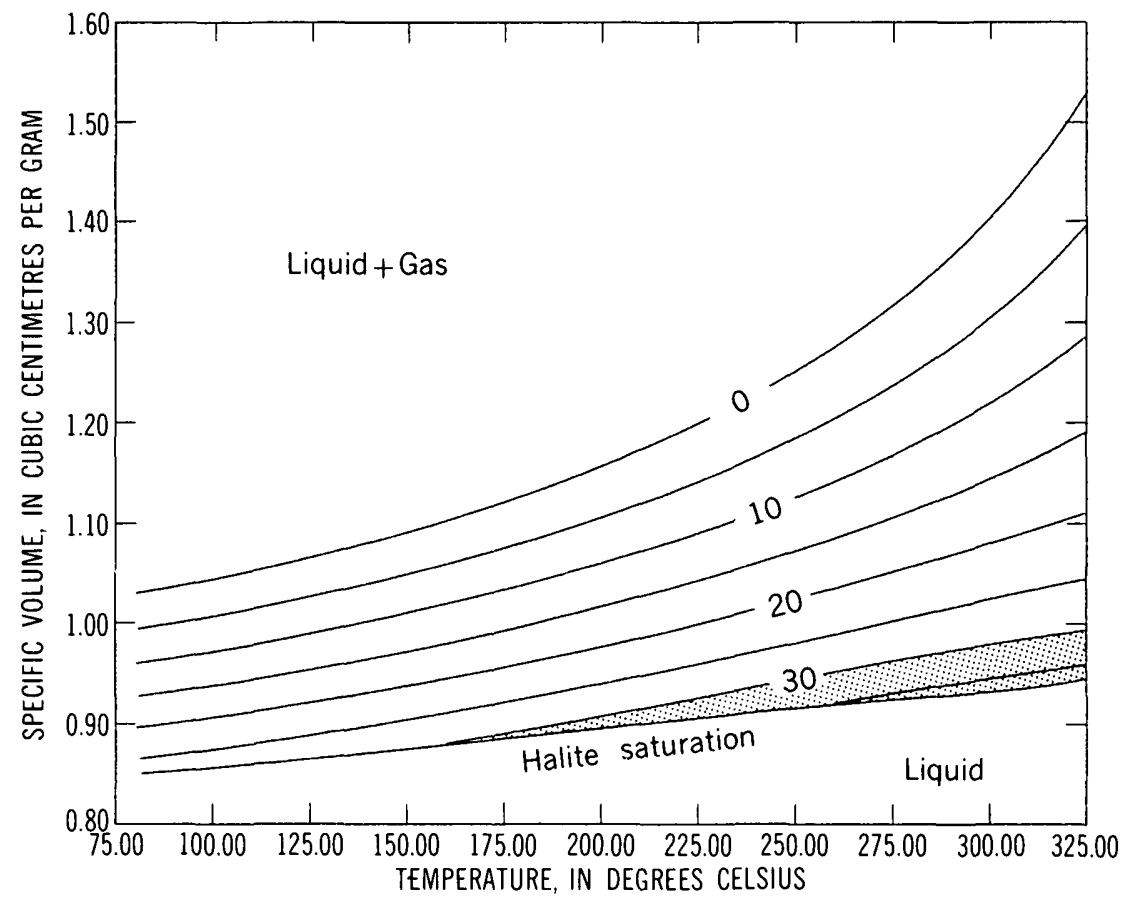

FIgURE 4.-Specific volume of the liquid phase for vapor-saturated $\mathrm{NaCl}$ solutions from 0 wt percent to halite saturation at $80^{\circ}$ to $325^{\circ} \mathrm{C}$. The contour interval is 5 wt percent $\mathrm{NaCl}$. The shaded zone was calculated by extrapolation of the functions given in the text.

where $V^{L}$ is the volume of the liquid containing a total of one mole of molecules. The term $N^{L}$ is the mole fraction of $\mathrm{NaCl}$ in the liquid and is given by equation 13 in terms of $x$, the molality of the solution.

$$
N^{L}=\frac{x}{1000 / W_{1}+x}
$$

$W_{1}$ is the molecular weight of $\mathrm{H}_{2} \mathrm{O}$. The molal volume of an $x$ molal solution of density $d$ is given by equation 14 .

$$
V^{L}=\frac{1}{d} \cdot \frac{1000+x W_{2}}{1000 / W_{1}+x} \quad\left(\mathrm{~cm}^{3} \mathrm{~mol}^{-1}\right)
$$

By substitution of equation 7 into equation 14 ,

$$
V^{L}=\frac{1000 v_{0}+x \phi}{1000 / W_{1}+x} \quad\left(\mathrm{~cm}^{3} \mathrm{~mol}^{-1}\right)
$$

Equation 12 was solved for the partial molal volume $\bar{V}_{1}^{L}$ by using equations 13, 15, and 8 through 10 and standard analytical techniques. 
The partial molal volume of $\mathrm{H}_{2} \mathrm{O}$ in the liquid phase for vaporsaturated $\mathrm{NaCl}$ solutions from 0 wt percent to halite saturation is shown on figure 5 . The contour interval is 5 wt percent $\mathrm{NaCl}$.

\section{PARTIAL MOLAL VOLUME OF $\mathrm{H}_{2} \mathrm{O}$ IN THE GAS}

The partial molal volume of $\mathrm{H}_{2} \mathrm{O}$ in the gas is assumed to be the same as the molal volume of pure gaseous $\mathrm{H}_{2} \mathrm{O}$ at the temperature and pressure of the liquid. The specific volume of pure gaseous $\mathrm{H}_{2} \mathrm{O}$ was obtained from equation 16 , which is attributed to Juza (1962) and given by Bain (1964, equation 41, p. 13) :

$$
v_{0}^{G}=\frac{R T_{x}}{p}+\alpha_{0}(\tau)+p \tau^{6} \alpha_{1}(\tau)+\left(p \tau^{6}\right)^{4} \alpha_{2}(\tau) \quad\left(\mathrm{cm}^{3} \mathrm{~g}^{-1}\right)
$$

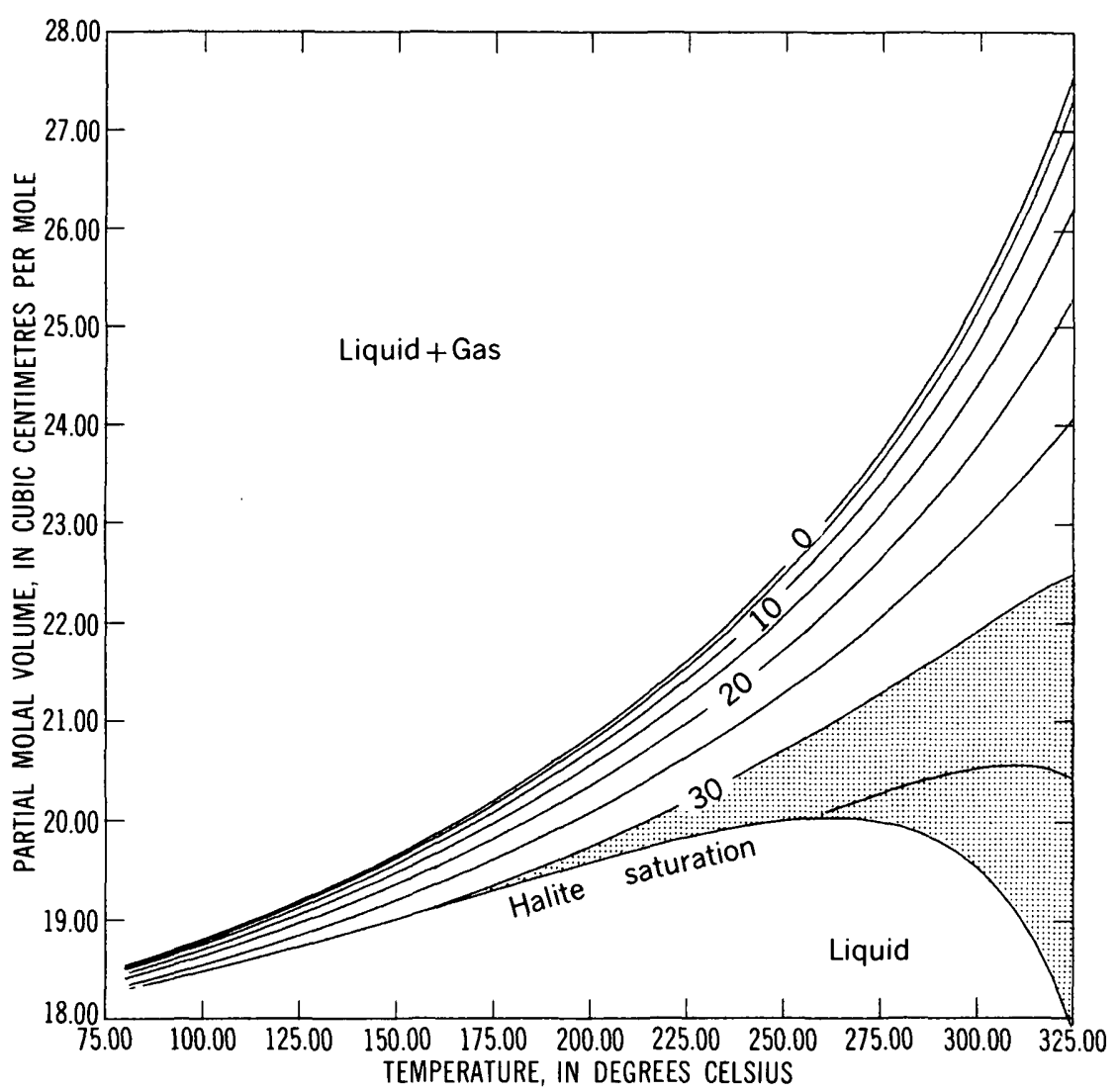

Figure 5.-The partial molal volume of $\mathrm{H}_{2} \mathrm{O}$ in the liquid phase for vaporsaturated $\mathrm{NaCl}$ solutions from 0 wt percent to halite saturation at $80^{\circ}$ to $325^{\circ}$ C. The contour interval is 5 wt percent $\mathrm{NaCl}$. The shaded zone was calculated by extrapolation of the functions given in the text. 
where $\tau=500 / T_{x}$ and the functions $\alpha_{1}(\tau)$ are given by summations of the form:

$$
\alpha_{i}(\tau)=\sum_{j=0}^{6} \alpha_{i j} \tau^{j}
$$

The constants $\alpha_{i j}$ are given in the foregoing section entitled "Empirical constants used in the text and calculations."

The molal volume of the gas was obtained by multiplying the specific volume $v_{0}^{\theta}$ by the molecular weight of $\mathrm{H}_{2} \mathrm{O}$ :

$$
\bar{V}_{1}^{G}=W_{1} v_{0}^{G} \quad\left(\mathrm{~cm}^{3} \mathrm{~mol}^{-1}\right)
$$

The specific volume of the gas phase for vapor-saturated $\mathrm{NaCl}$ solutions from 0 wt percent to halite saturation is given on figure 6. The contour interval is for 5 wt percent $\mathrm{NaCl}$ contained in the coexisting liquid.

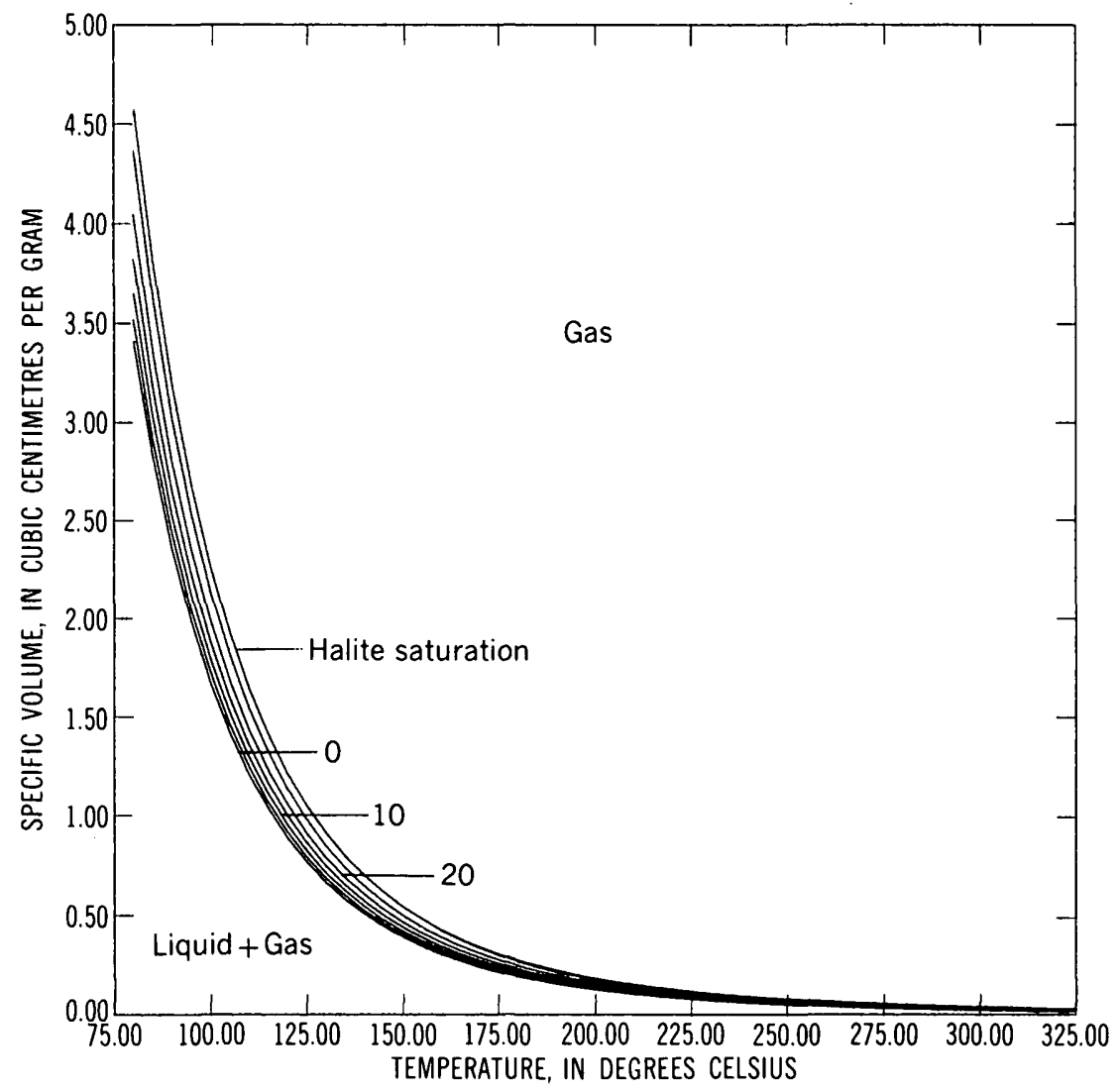

FIGURE 6.-The specific volume of the gas phase for liquid-saturated $\mathrm{NaCl}$ solutions from 0 wt percent to halite saturation at $80^{\circ}$ to $325^{\circ} \mathrm{C}$. The contour interval is 5 percent $\mathrm{NaCl}$ contained in the coexisting liquid. 


\section{ENTHALPY FUNCTIONS}

PARTIAL MOLAL ENTHALPY OF $\mathrm{H}_{2} \mathrm{O}$ IN THE GAS

The partial molal enthalpy of $\mathrm{H}_{2} \mathrm{O}$ in the gas is assumed to be the same as the molal enthalpy of pure $\mathrm{H}_{2} \mathrm{O}$ gas at the temperature and pressure of the liquid solution. Bain (1964) derived the specific enthalpy function for gaseous $\mathrm{H}_{2} \mathrm{O}$, equation 20 , from equation 16 by using the relation given by equation 19 .

$$
\begin{gathered}
\left(\frac{\partial h}{\partial p}\right)_{T}=v-T\left(\frac{\partial v}{\partial T}\right)_{p} \\
h_{0}^{\theta}-h_{\bullet}^{\theta}=\frac{1}{10}\left[p\left[\alpha_{0}+\tau \frac{d \alpha_{0}}{d \tau}\right]+\frac{1}{2} p^{2} \tau^{6}\left[\alpha_{1}+\tau \frac{d \alpha_{1}}{d \tau}\right]\right. \\
\left.+\frac{1}{5} p^{5} \tau^{24}\left[\alpha_{2}+\tau \frac{d \alpha_{2}}{d \tau}\right]\right]\left(\mathrm{J} \mathrm{g} \mathrm{g}^{-1}\right)
\end{gathered}
$$

where$$
\mathrm{h}^{G}=1809.25+1.48286 \mathrm{~T}+3.79025 \times 10^{-4} \mathrm{~T}^{2}
$$$$
+46.147 \ln T \quad\left(\mathrm{~J} \mathrm{~g}^{-1}\right)
$$

Because the gas is assumed to be $\mathrm{H}_{2} \mathrm{O}$ only, the partial molal enthalpy of $\mathrm{H}_{2} \mathrm{O}$ is :

$$
\bar{H}_{1}^{G}=W_{1} h_{0}^{G} \quad\left(\mathrm{~J} \mathrm{~mol}^{-1}\right)
$$

ENTHALPY DIFFERENCE BETWEEN THE GAS AND THE LIQUID AT CONSTANT LIQUID COMPOSITION

From equation $2 \mathrm{a}$ the enthalpy difference, $\Delta H_{1}$ may be derived:

$$
\Delta \bar{H}_{1}=\left(\bar{H}_{1}^{G}-\bar{H}_{1}^{L}\right)=\left(\bar{V}_{1}^{G}-\bar{V}_{1}^{L}\right) T_{x}\left(\frac{\partial p}{\partial T_{x}}\right)_{x}\left(\mathrm{~J} \mathrm{~mol}^{-1}\right)
$$

$\bar{V}_{1}^{G}$ and $\bar{V}_{1}^{L}$ are calculated by using equations 18 and 12 , respectively. The following identity enables one to evaluate the partial derivative $\left(\partial p / \partial T_{x}\right)_{x}$ :

$$
\left(\frac{\partial p}{\partial T_{x}}\right)_{x}=\frac{\partial p}{\partial T_{0}} \cdot \frac{\partial T_{0}}{\partial T_{x}}
$$

Equation 6 gives the relation between pressure and temperature for $\mathrm{H}_{2} \mathrm{O}$. The derivative $\left(\partial p / \partial T_{0}\right)$ was obtained analytically from equation 6 . Equation $3 \mathrm{a}$, which is given below and which was derived from equation 3 by inserting the appropriate substitutions, gives the relation between the temperature of the solution $T_{x}$ and the temperature of the reference substance $T_{0}$ at the same pressure: 


$$
\ln T_{0}=\frac{1}{a+b T_{x}} \ln T_{x} \quad \text { (kelvins, } \mathrm{K} \text { ) }
$$

The partial derivative $\left(\partial T_{0} / \partial T_{x}\right)$ was derived analytically from equation 3a. The partial molal enthalpy difference $\Delta \bar{H}_{1}$ was calculated by inserting the appropriate functions into equation 23 .

\section{PARTIAL MOLAL ENTHALPY OF $\mathrm{H}_{2} \mathrm{O}$ IN THE LIQUID AT CONSTANT COMPOSITION}

The partial molal enthalpy of $\mathrm{H}_{2} \mathrm{O}$ in the liquid was obtained by subtracting the enthalpy of vaporization from the partial molal enthalpy of $\mathrm{H}_{2} \mathrm{O}$ in the gas:

$$
\bar{H}_{1}^{L}=\bar{H}_{1}^{G}-\Delta \bar{H}_{1} \quad\left(\mathrm{~J} \mathrm{~mol}^{-1}\right)
$$

Figure 7 shows the partial molal enthalpy of $\mathrm{H}_{2} \mathrm{O}$ in the liquid (lower curves) and the gas (upper curves) for vaporsaturated $\mathrm{NaCl}$ solutions from 0 wt percent to halite saturation. The contour interval is 5 wt percent $\mathrm{NaCl}$ contained in the liquid phase.

\section{ENTROPY FUNCTIONS}

\section{PARTIAL MOLAL ENTROPY OF $\mathrm{H}_{2} \mathrm{O}$ IN THE GAS}

Bain (1964), using the relation given in equation 26, derived the entropy of pure gaseous $\mathrm{H}_{2} \mathrm{O}$, equation 27 , from equation 16 , above.

$$
\begin{gathered}
\left(\frac{\partial s}{\partial p}\right)_{T}=-\left(\frac{\partial v}{\partial T}\right)_{p} \\
{\left[s_{0}^{G}+\frac{R}{10} \ln p\right]-\left[s_{0}+\frac{R}{10} \ln p\right]=\frac{\tau}{5000}\left[p \frac{d \alpha_{0}}{d \tau}+\frac{1}{2} p^{2} \tau^{\tau}\left[6 \alpha_{1}+\tau \frac{d \alpha_{1}}{d \tau}\right]\right.} \\
\left.+\frac{1}{5} p^{6} \tau^{24}\left[24 \alpha_{2}+\tau \frac{d \alpha_{2}}{d \tau}\right]\right]\left(\mathrm{J} \mathrm{g}^{-1} \mathrm{~K}^{-1}\right)
\end{gathered}
$$

where

$\left[\dot{s}_{0}^{G}+\frac{R}{10} \ln p\right]_{x}=-1.5535+1.48286 \ln T+7.85050 \times 10^{-4} T-46.147 / T$

$$
\left(\mathrm{J} \mathrm{g}^{-1} \mathrm{~K}^{-1}\right)
$$

Because the gas is assumed to be $\mathrm{H}_{2} \mathrm{O}$ only, the partial molal entropy of $\mathrm{H}_{2} \mathrm{O}$ is :

$$
\bar{S}_{1}^{G}=W_{1} s_{0}^{G} \quad\left(\mathrm{~J} \mathrm{~mol}^{-1} \mathrm{~K}^{-1}\right)
$$




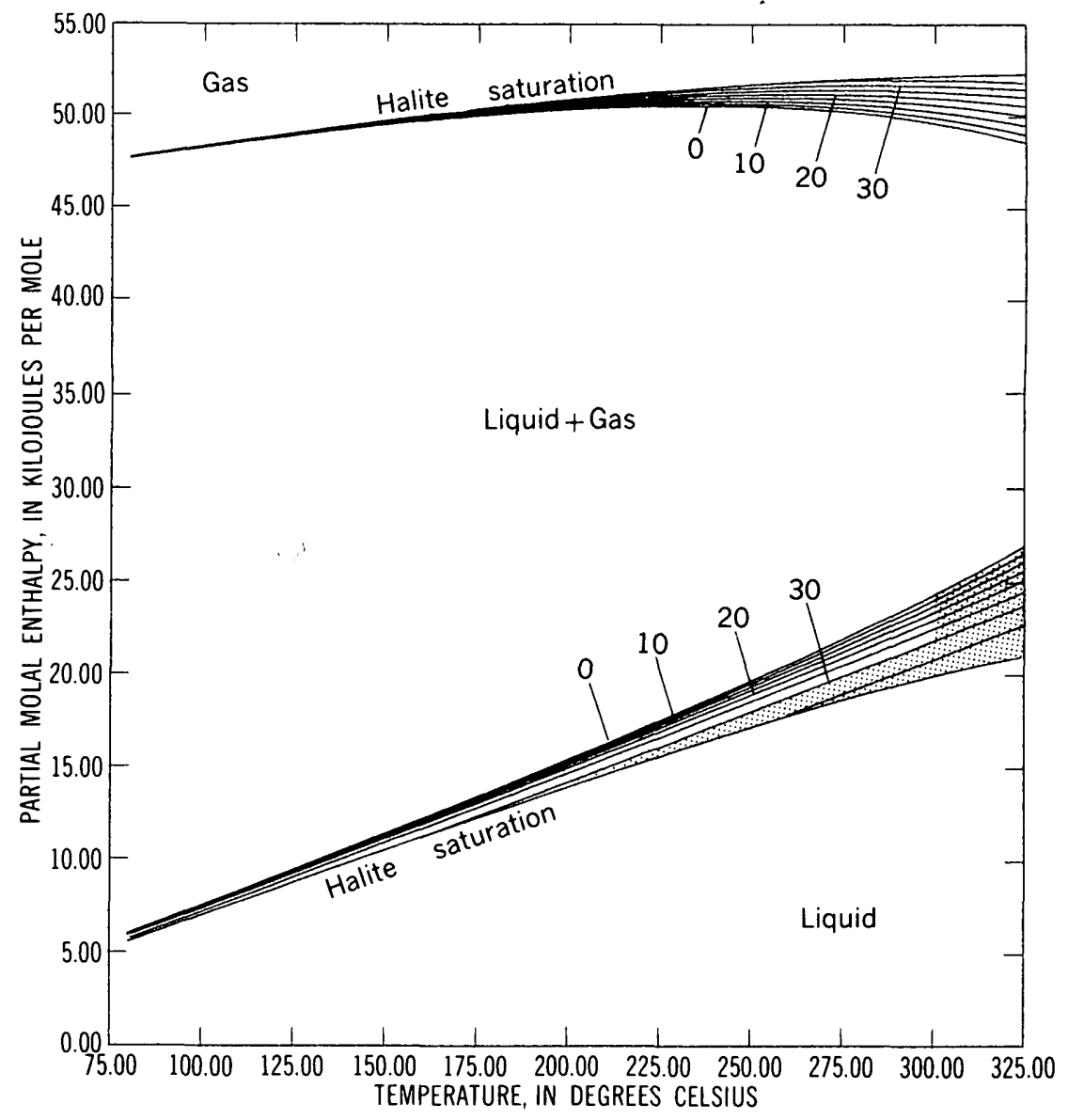

Figure 7.-The partial molal enthalpy of $\mathrm{H}_{2} \mathrm{O}$ in the liquid (lower curves) and the gas (upper curves) for vapor-saturated $\mathrm{NaCl}$ solutions from 0 wt percent to halite saturation at $80^{\circ}$ to $325^{\circ} \mathrm{C}$. The contour interval is 5 wt percent $\mathrm{NaCl}$ contained in the liquid. The shaded zone was calculated by extrapolation of the density and vapor pressure functions given in the text.

\section{ENTROPY DIFFERENCE BETWEEN THE GAS AND THE LIQUID AT CONSTANT LIQUID COMPOSITION}

At equilibrium between the gas and the liquid, the free-energy difference is zero. Therefore, the entropy difference was calculated from:

$$
\Delta \bar{S}_{1}=\frac{\Delta \bar{H}_{1}}{T_{x}} \quad\left(\mathrm{~J} \mathrm{~mol}^{-1} \mathrm{~K}^{-1}\right)
$$




\section{PARTIAL MOLAL ENTROPY OF $\mathrm{H}_{2} \mathrm{O}$ IN THE LIQUID AT CONSTANT COMPOSITION}

Similar to the calculation of the partial molal enthalpy of $\mathrm{H}_{2} \mathrm{O}$ in the liquid, which is given above, the partial molal entropy of $\mathrm{H}_{2} \mathrm{O}$ in the liquid was calculated from the following relation:

$$
\bar{S}_{1}^{L}=\bar{S}_{1}^{\theta}-\Delta \bar{S}_{1} \quad\left(\mathrm{~J} \mathrm{~mol}^{-1} \mathrm{~K}^{-1}\right)
$$

Figure 8 shows the partial molal entropy of $\mathrm{H}_{2} \mathrm{O}$ in the liquid (lower curve) and the gas (upper curve) for vapor-saturated $\mathrm{NaCl}$ solutions. The contour interval is 5 wt percent $\mathrm{NaCl}$ contained in the liquid phase.

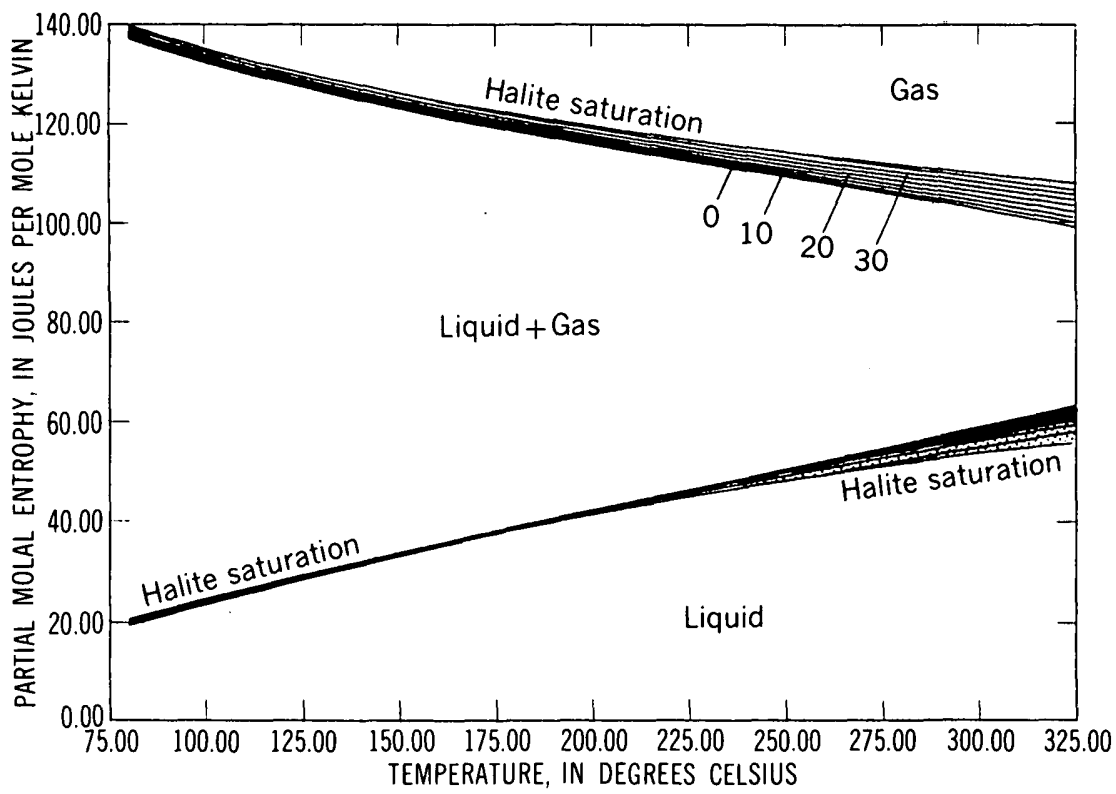

Figure 8.-The partial molal entropy of $\mathrm{H}_{2} \mathrm{O}$ in the liquid (lower curves) and the gas (upper curves) for vapor-saturated $\mathrm{NaCl}$ solutions from 0 wt percent to halite saturation at $80^{\circ}$ to $325^{\circ} \mathrm{C}$. The contour interval is 5 wt percent $\mathrm{NaCl}$ contained in the liquid. The shaded zone (temperatures greater than $300^{\circ} \mathrm{C}$ or concentration greater than 30 wt percent) on the lower curves was calculated by extrapolation of the density and vapor pressure functions given in the text. In the gas phase, the partial molal entropy increases with $\mathrm{NaCl}$ concentration. In the liquid phase, the contours cross over so that at low temperature the halite-saturated liquid has the highest partial molal entropy, whereas at high temperatures, the $\mathrm{H}_{2} \mathrm{O}$ rich liquid has the highest partial molal entropy. For details, the reader is referred to the data given in the tables. 


\section{COMPOSITION OF THE LIQUID AT HALITE SATURATION}

R. W. Potter, II (written commun., 1975) kindly supplied the following function for the concentration of a solution that is both vapor and halite saturated. The analysis is based upon published data between $0^{\circ}$ and $455^{\circ} \mathrm{C}$ and Potter's recent measurements between $150^{\circ}$ and $273^{\circ} \mathrm{C}$. The standard error of estimate is 0.16 wt percent.

$$
w_{\mathrm{sat}}=26.218+7.2 \times 10^{-3} t+1.06 \times 10^{-4} t^{2}(\text { wt percent } \mathrm{NaCl})
$$

\section{THE REFERENCE STATE FOR ENTHALPY AND ENTROPY}

In the foregoing functions and in all calculations, the reference state was that of the liquid phase for $\mathrm{H}_{2} \mathrm{O}$ at $0 \mathrm{~mol} \mathrm{NaCl} / \mathrm{kg} \mathrm{H}_{2} \mathrm{O}$ at the ice-liquid-vapor triple point of $0.01^{\circ} \mathrm{C}$. The entropy and enthalpy of liquid $\mathrm{H}_{2} \mathrm{O}$ was 0.0 by definition.

\section{TABLES FOR NaCl SOLUTIONS}

Tables 1 through 28 give the temperature, pressure, density of the liquid, and the specific volumes of the liquid and the gas at constant composition and $5^{\circ}$ intervals between $80^{\circ} \mathrm{C}$ (or at the $5^{\circ}$ interval just above halite saturation) and $325^{\circ} \mathrm{C}$. The partial molal quantities of entropy and enthalpy for $\mathrm{H}_{2} \mathrm{O}$ in the gas and the liquid and of the volume for $\mathrm{H}_{2} \mathrm{O}$ in the liquid are also presented. Concentrations are given in both $\mathrm{mol} \mathrm{NaCl} / \mathrm{kg} \mathrm{H}_{2} \mathrm{O}$ (molal $\mathrm{NaCl}$ ) and weight percent $\mathrm{NaCl}$. Tables $3,6,10,13,17,21$, and 26 give the data at $5,10,15,20,25,30$, and 35 wt percent $\mathrm{NaCl}$, respectively. The other tables give the data at intervals of $0.5 \mathrm{~mol}$ $\mathrm{NaCl} / \mathrm{kg} \mathrm{H} \mathrm{H}_{2} \mathrm{O}$.

Tables 29 and 30 give the same data but at the given concentration on the halite saturation equilibrium between $80^{\circ}$ and $325^{\circ} \mathrm{C}$. Table 29 is in concentration units of wt percent $\mathrm{NaCl}$ and table 30 in $\mathrm{mol} \mathrm{NaCl} / \mathrm{kg} \mathrm{H}_{2} \mathrm{O}$.

The tables were calculated using the functions that are given in the preceding section. Data contained within parentheses were calculated by extrapolation of the functions beyond their range.

A detailed analysis of the accuracy and precision of the tabulated data is not possible in this preliminary report. Seven semitheoretical or empirical equations were used to prepare the tables:

$\begin{array}{ccl}\text { Equation } & \text { Property } & \text { Source } \\ (6) & p_{0} & \text { Bain (1964) } \\ (3) & T_{x} \text { at } p_{x}=p_{0} & \text { This report } \\ (11) & v_{0}^{L}\left(=1 / d_{0}^{L}\right) & \text { Smith and Keyes (1934) } \\ (7) & d^{L} & \text { Haas (1970) } \\ (16) & v_{0}^{a} & \text { Juza (1962, cited in Bain, 1964) }\end{array}$


Equation

$$
\begin{array}{cc}
\begin{array}{l}
\text { Property } \\
h_{0}^{\circ}\left(\text { at } p_{0}=0\right)
\end{array} & \text { Bain (1964) } \\
{\left[s_{0}^{a}-(R / 10) \ln p\right]^{*}} & \text { Bain (1964) }
\end{array}
$$

Source

For the pure $\mathrm{H}_{2} \mathrm{O}$ component, Bain (1964) gave no estimate for either the precision or accuracy of equations $6,16,21$, and 28 , except that the equations reproduce very closely the International Skeleton Tables of the Thermodynamic Properties of Water Substance, 1963 (Meyer and others, 1967). In the temperature range of this report, $80^{\circ}$ to $325^{\circ} \mathrm{C}$, the value for the accuracy of the International Skelton Tables is less than or equal to the percentages tabulated below:

$\begin{array}{ll}\text { pressure } & 0.05 \text { percent } \\ \text { volume of the liquid } & 0.05 \text { percent } \\ \text { volume of the gas } & 0.2 \text { percent } \\ \text { enthalpy of the liquid } & 0.08 \text { percent } \\ \text { enthalpy of the gas } & 0.2 \text { percent }\end{array}$

Smith and Keyes (1934) reported the accuracy of equation 11 as one part in 2,000 which is consistent with the above tabulation.

For the liquids in the $\mathrm{H}_{2} \mathrm{O}-\mathrm{NaCl}$ system, the density of the solution is calculated using equation 7 with an accuracy of about $0.006 \mathrm{~g} / \mathrm{cm}^{3}$, and the vapor pressure with an estimated accuracy of 0.6 percent. No accuracy for the partial molal quantities for $\mathrm{H}_{2} \mathrm{O}$ in the liquid $\left(\bar{V}_{1}^{L}, \bar{H}_{1}^{L}\right.$, and $\left.\bar{S}_{1}^{L}\right)$ can be estimated because these properties were calculated in part by the partial differentiation of equations 3 and 7.

In the tables, data are given with as many as six digits. This is particularly true for data for entropy and enthalpy, where most of the value represents the relative difference in the property between $T$ and $0.01^{\circ} \mathrm{C}$ and only a minor part of the value is due to change in concentration. The number of digits reported in the tables is governed by the need to have a reasonable resolution in the property when small changes in concentration or temperature are considered.

\section{REFERENCES CITED}

Bain, R. W., 1964, Steam tables, 1964: Edinburgh, H. M. Stationery Office, $147 \mathrm{p}$.

Commission on Atomic Weights, 1972, Atomic weights for 1971: Pure and Appl. Chemistry, v. 30, p. 637-649.

Committee on Data for Science and Technology, 1973, Recommended consistent values of the fundamental physical constants, 1973: CODATA Bull. 11, p. 1-8. 
Dalton, B. J., and Barieau, R. E., 1968, Equations for calculating various thermodynamic functions of a two-component system from an empirical equation of state, including liquid-vapor equilibria data: U.S. Bur. Mines Rept. Inv. 7076, 69 p.

Gardner, E. R., 1969, Osmotic coefficients of some aqueous sodium chloride solutions at high temperature: Faraday Soc. Trans., v. 65, p. 91-97.

Gardner, E. R., Jones, P. J., and deNordwall, H. J., 1963, Osmotic coefficients of some aqueous sodium chloride solutions at high temperature: Faraday Soc. Trans., v. 59, p. 1994-2000.

Haas, J. L., Jr., 1970, An equation for the density of vapor-saturated $\mathrm{NaCl}-$ $\mathrm{H}_{2} \mathrm{O}$ solutions from $75^{\circ}$ to $325^{\circ}$ C: Am. Jour. Sci., v. 269, no. 5, p. 489493.

1971a, Thermodynamic correlations for brines: $\mathrm{NaCl}-\mathrm{H}_{2} \mathrm{O}$ liquid-vapor equilibria [abs.] : Am. Geophys. Union Trans., v. 52', no. 4, p. 379.

$1971 \mathrm{~b}$, The effect of salinity on the maximum thermal gradient of a hydrothermal system at hydrostatic pressure: Econ. Geology, v. 66, no. 6, p. 940-946.

Juza, J., 1962, Equation of state for saturated superheated steam: Prague, Czechoslovak Acad. Sci., Mechanical Engineering Research Inst.

Keenan, J. H., Keyes, F. G., Hill, P. G., and Moore, J. G., 1969, Steam tables; Thermodynamic properties of water, including vapor, liquid and solid phases: New York, John Wiley and Sons, $162 \mathrm{p}$.

Lindsay, W. T., Jr., and others, 1968, Vapor-pressure lowering of aqueous solutions at elevated temperatures: U.S. Office Saline Water, Research and Devel. Prog. Rept. 347, 235 p.

Liu, C. T., and Lindsay, W. T., Jr., 1971, Thermodynamic properties of aqueous solutions at high temperatures: U.S. Office Saline Water, Research and Devel. Prog. Rept. 722, 124 p.

Meyer, C. A., McClintock, R. B., Silvestri, G. J., and Spencer, R. C., Jr., 1967, Thermodynamic and transport properties of steam: New York, Am. Soc. Mechanical Engineers, 328 p.

Momicchioli, F., Devoto, O., Grandi, G., and Cocco, G., 1970, Thermodynamic properties of concentrated solutions of strong electrolytes. I. Activity coefficients of water from freezing-point depressions for alkali chlorides: Bunsengesell. Phys. Chemie Berichte, v. 74, p. 59-66.

Natl. Acad. Sci., 1974, Conf. on Thermodynamics and National Energy Problems: Washington, D.C., Natl. Acad. Sci., 424 p.

Natl. Research Council, 1928, International critical tables of numerical data, physics, chemistry, and technology: New York, McGraw-Hill, v. 3, 444 p.

Othmer, D. F., and Chen, H. T., 1968, Correlating and predicting thermodynamic data: Indus. Eng. Chemistry, v. 60, no. 4, p. 39-61; reprinted in Am. Chem. Soc., Applied Thermodynamics: Washington, D.C., Am. Chem. Soc., p. 115-139, 1968.

Othmer, D. F., and Yu, E. S., 1968, Correlating vapor pressures and vapor volumes. Use of reference substance equations: Indus. Eng. Chemistry, v. 60 , no. 1 , p. $22-35$.

Robinson, R. A., and Stokes, R. H. 1959, Electrolyte solutions [2d ed., rev. 1970]: London, Butterworths, 571 p. (Especially p. 478 and 481.)

Smith, L. B., and Keyes, F. G., 1934, The volumes of unit mass of liquid water and their correlation as a function of pressure and temperature. Part III, Steam research program: Am. Acad. Arts Sci. Proc., v. 69, p. 285-312. 
Smith, R. P., 1939, The boiling point elevation. II. Sodium chloride 0.05 to $1.0 M$ and 60 to $100^{\circ}:$ Am. Chem. Soc. Jour., v. 61, p. 500-503.

Smith, R. P., and Hirtle, D. S., 1939, The boiling point elevation. III. Sodium chloride 1.0 to $4.0 \mathrm{M}$ and 60 to $100^{\circ}: \mathrm{Am}$. Chem. Soc. Jour., v. 61, p. 11231126.

Sourirajan, S., and Kennedy, G. C., 1962, The system $\mathrm{H}_{2} \mathrm{O}-\mathrm{NaCl}$ at elevated temperatures and pressures: Am. Jour. Sci., v. 260, no. 2, p. 115-141.

U.S. A tomic Energy Commission, Ad Hoc Committee on Geothermal Chemistry, 1974, A recommended research program in geothermal chemistry: U.S. Atomic Energy Comm., Pub. WASH-1344, 48 p. 

TABLES $1-30$ 


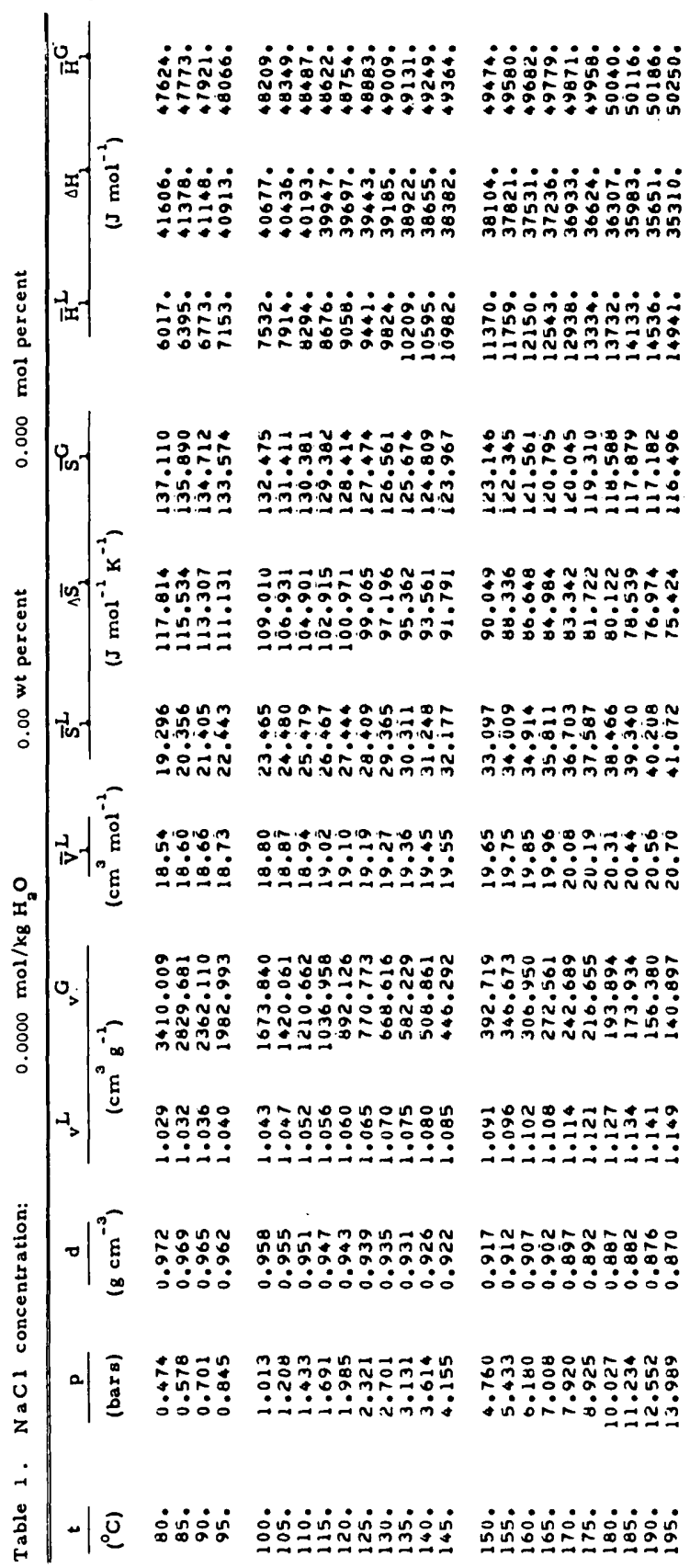




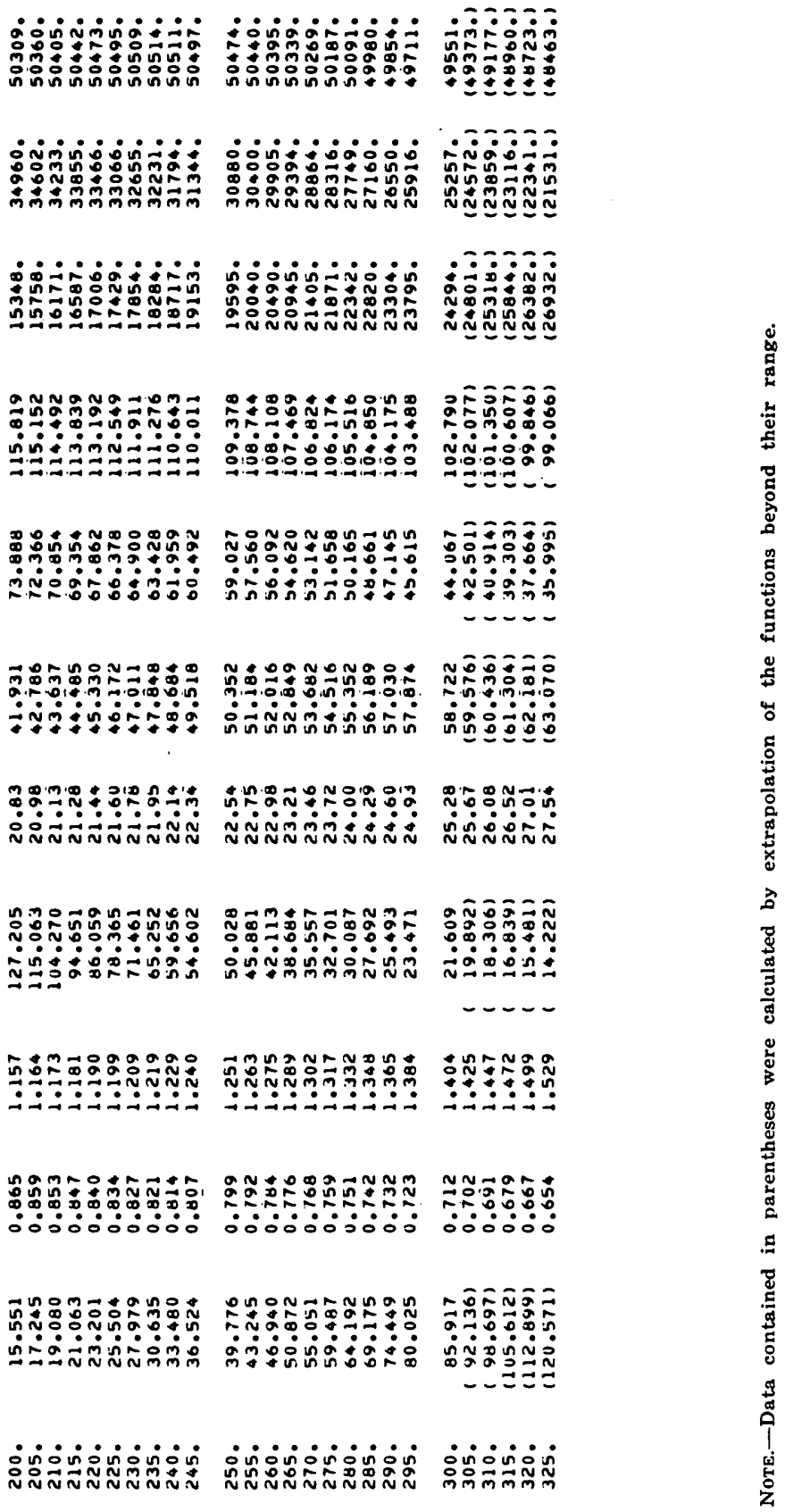




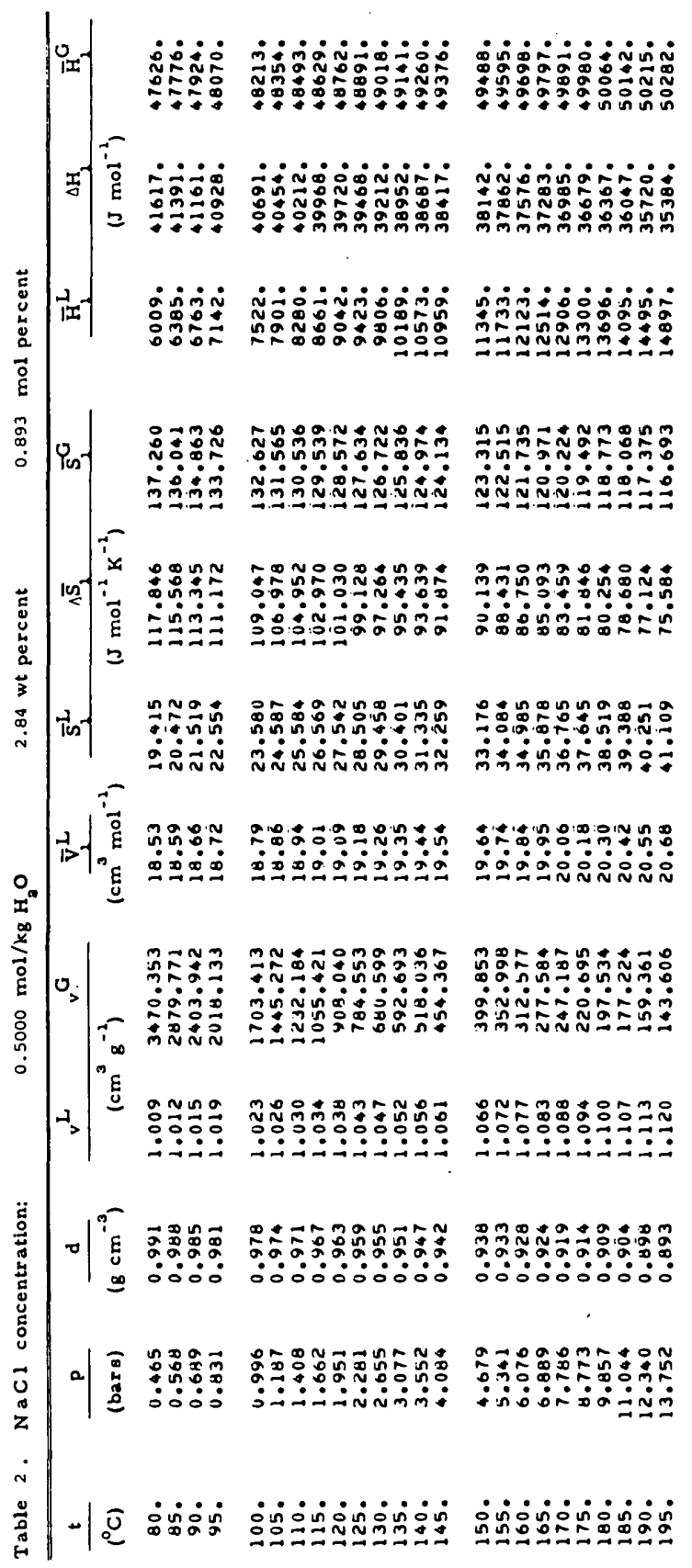




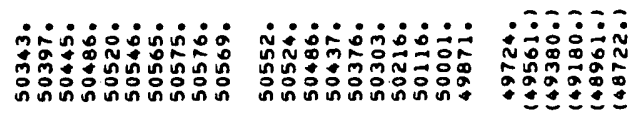

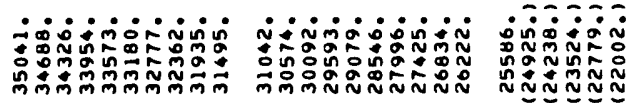

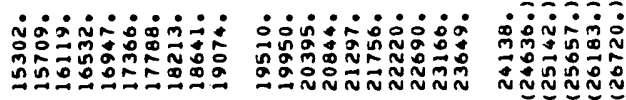

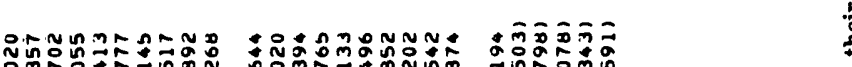

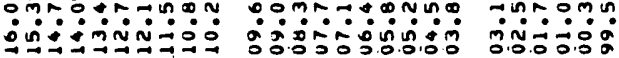

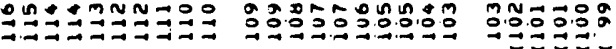

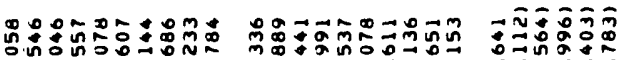

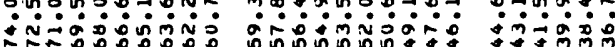

- - -

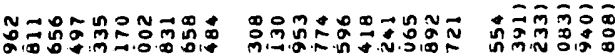

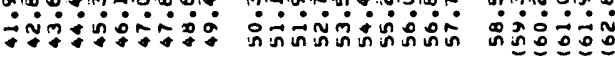

n.:ำ

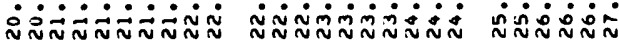

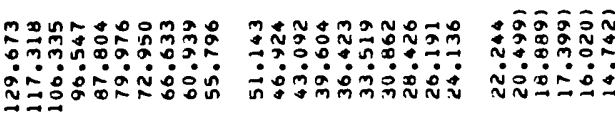

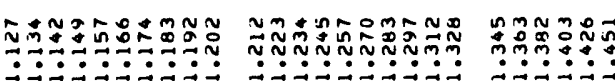

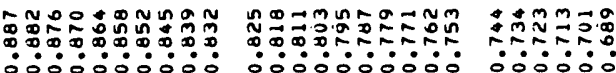

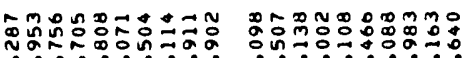

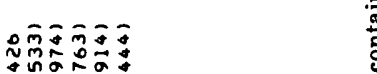

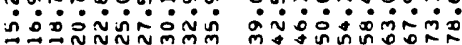

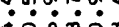

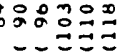

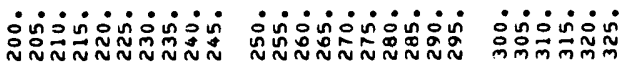




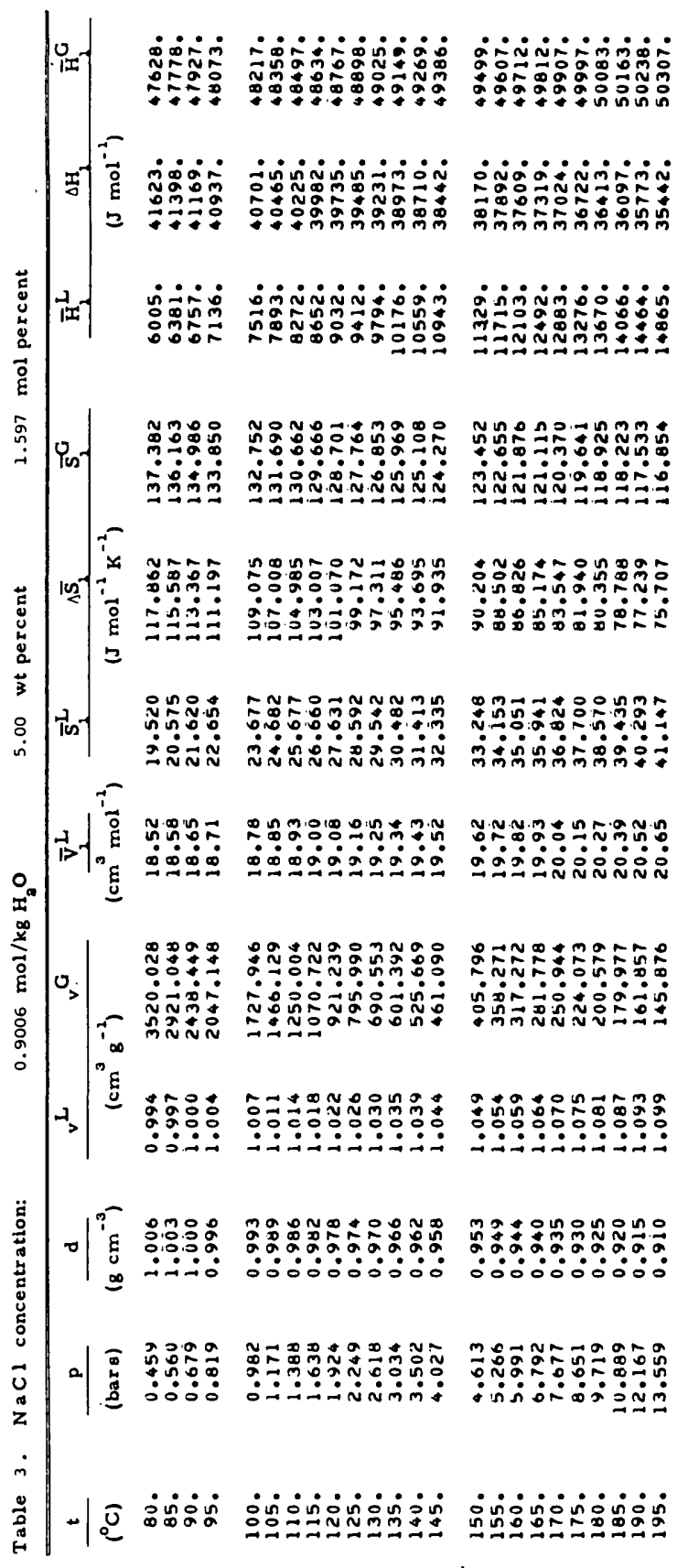




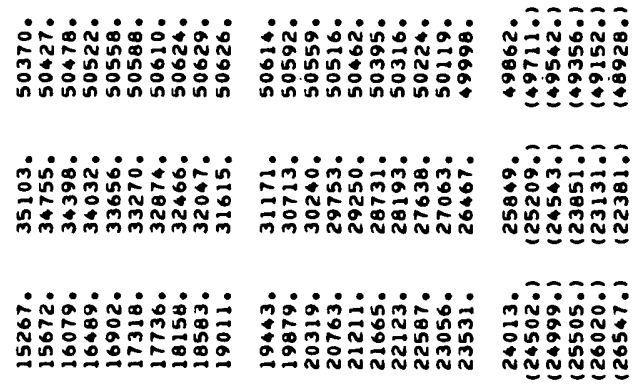

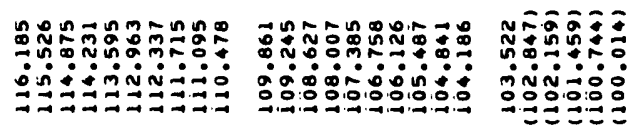

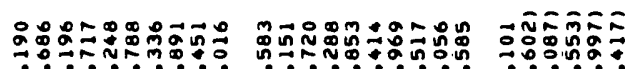

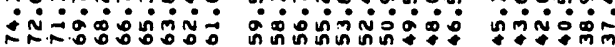

na.

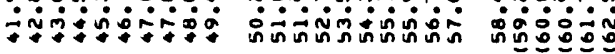

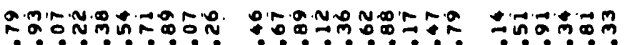

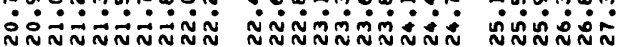

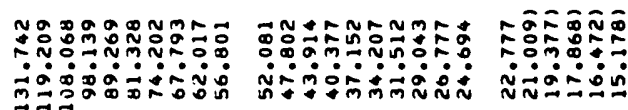

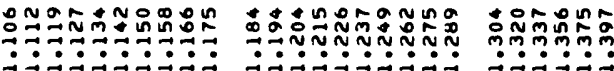

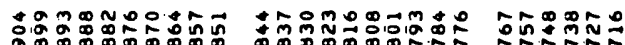

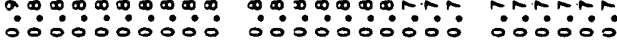

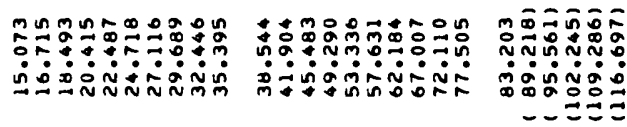

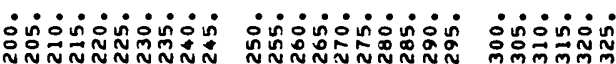




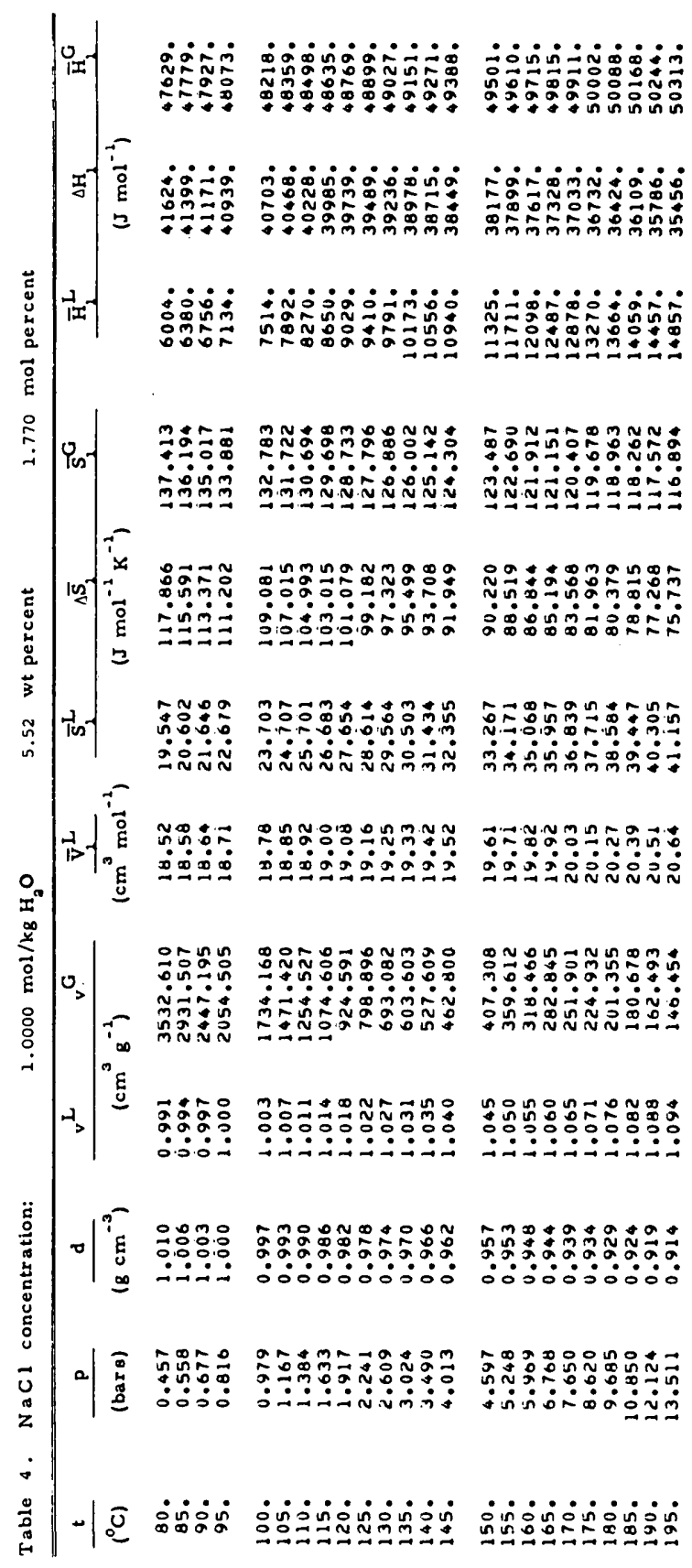




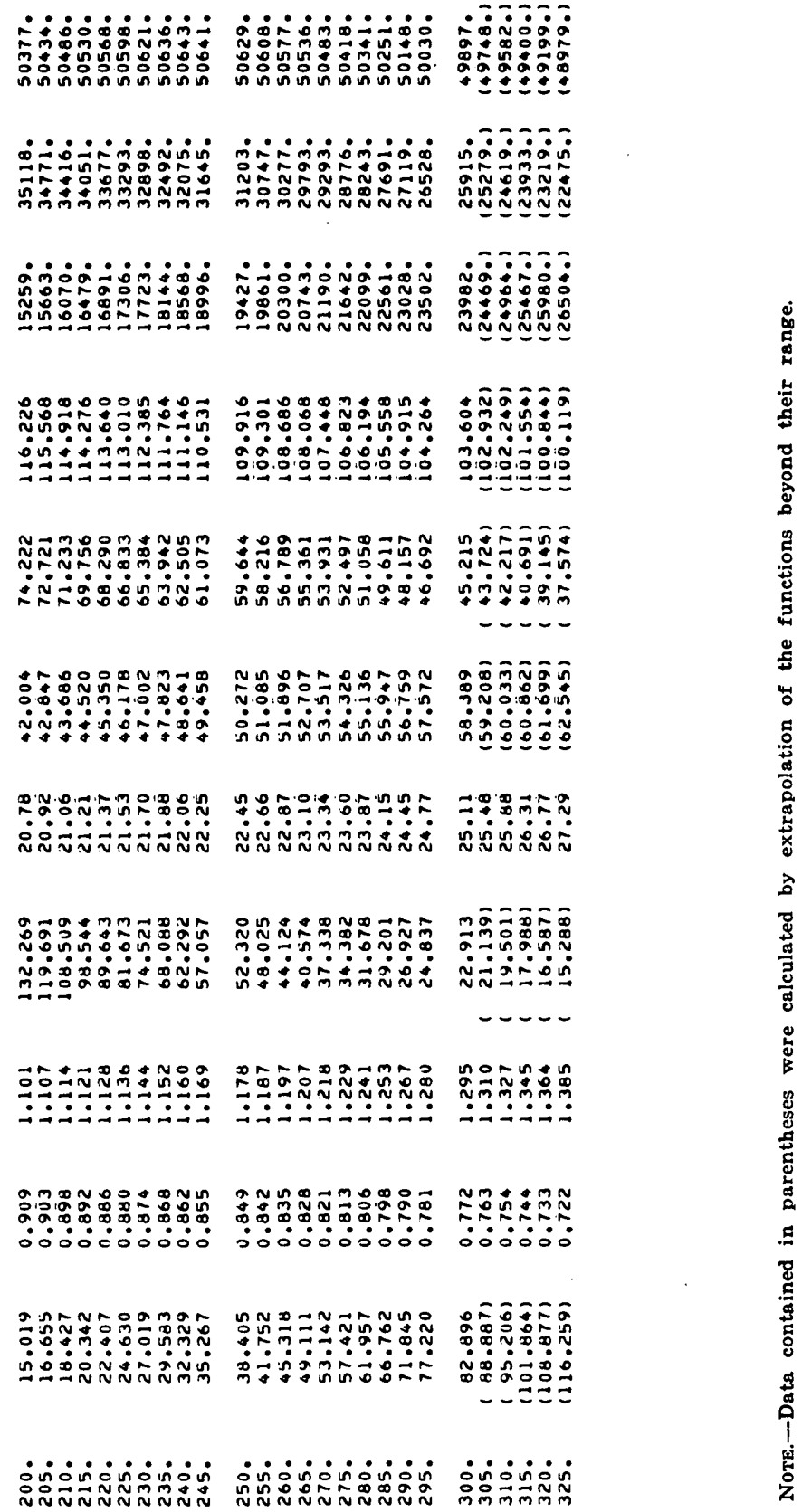




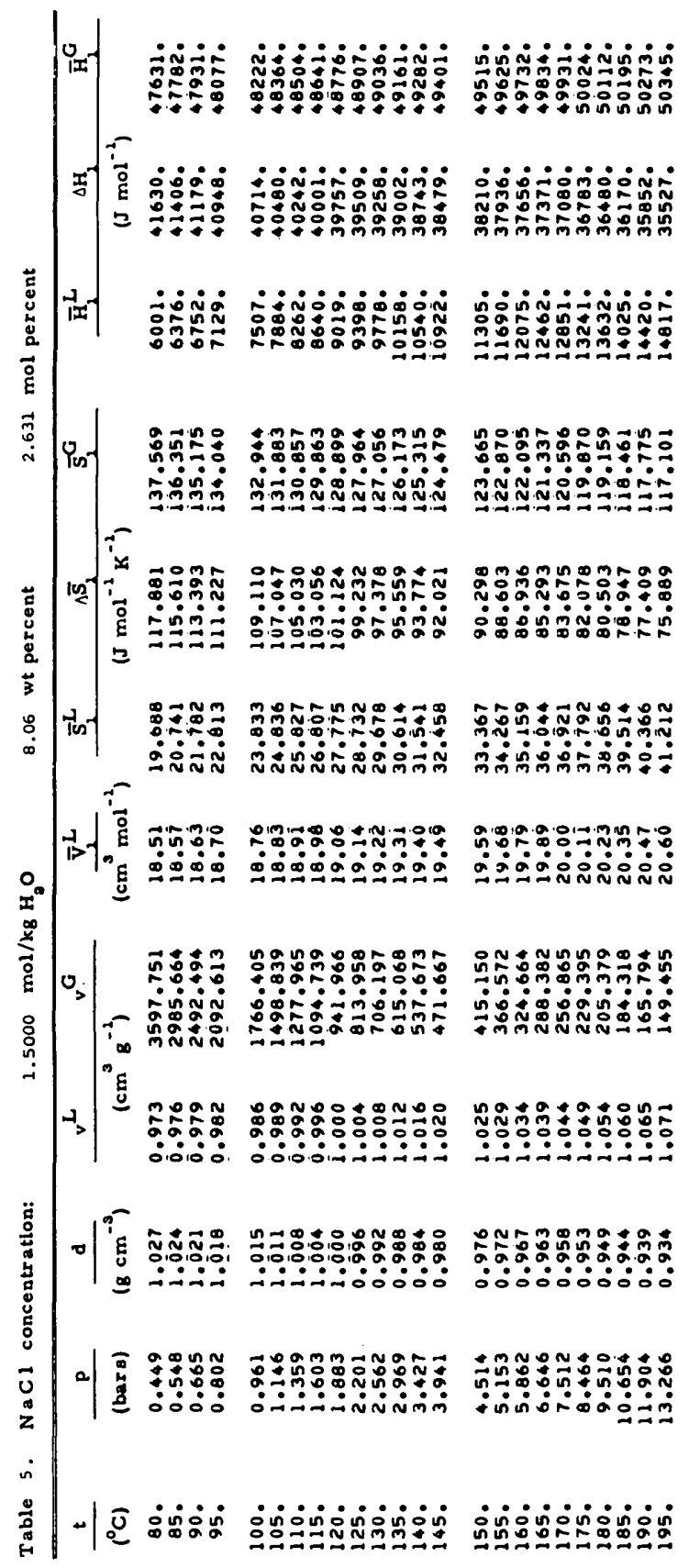



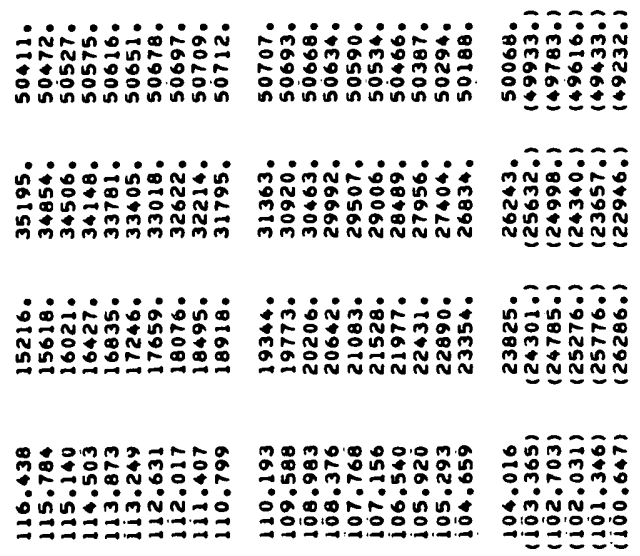

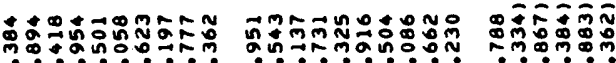
ñ

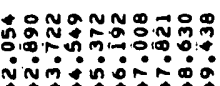

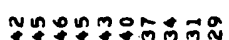

$a=0 \hat{0} \bar{ท}$

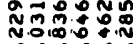

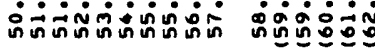

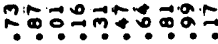

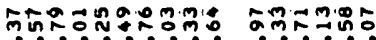

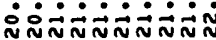

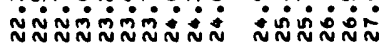

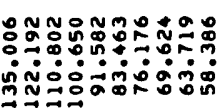

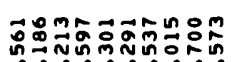

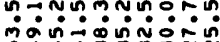

$\operatorname{na} 0 \hat{0}$

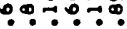

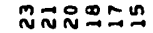

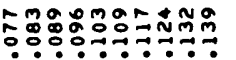

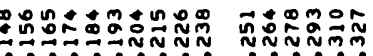

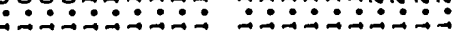
$\because \div: \div$

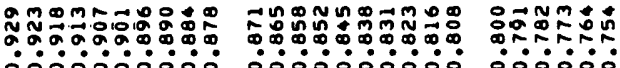

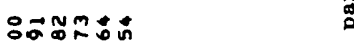

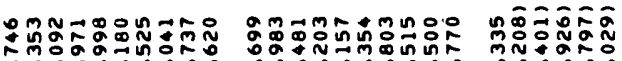

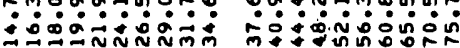
कालिू:

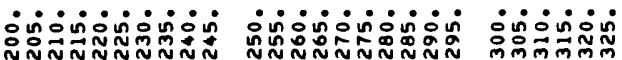




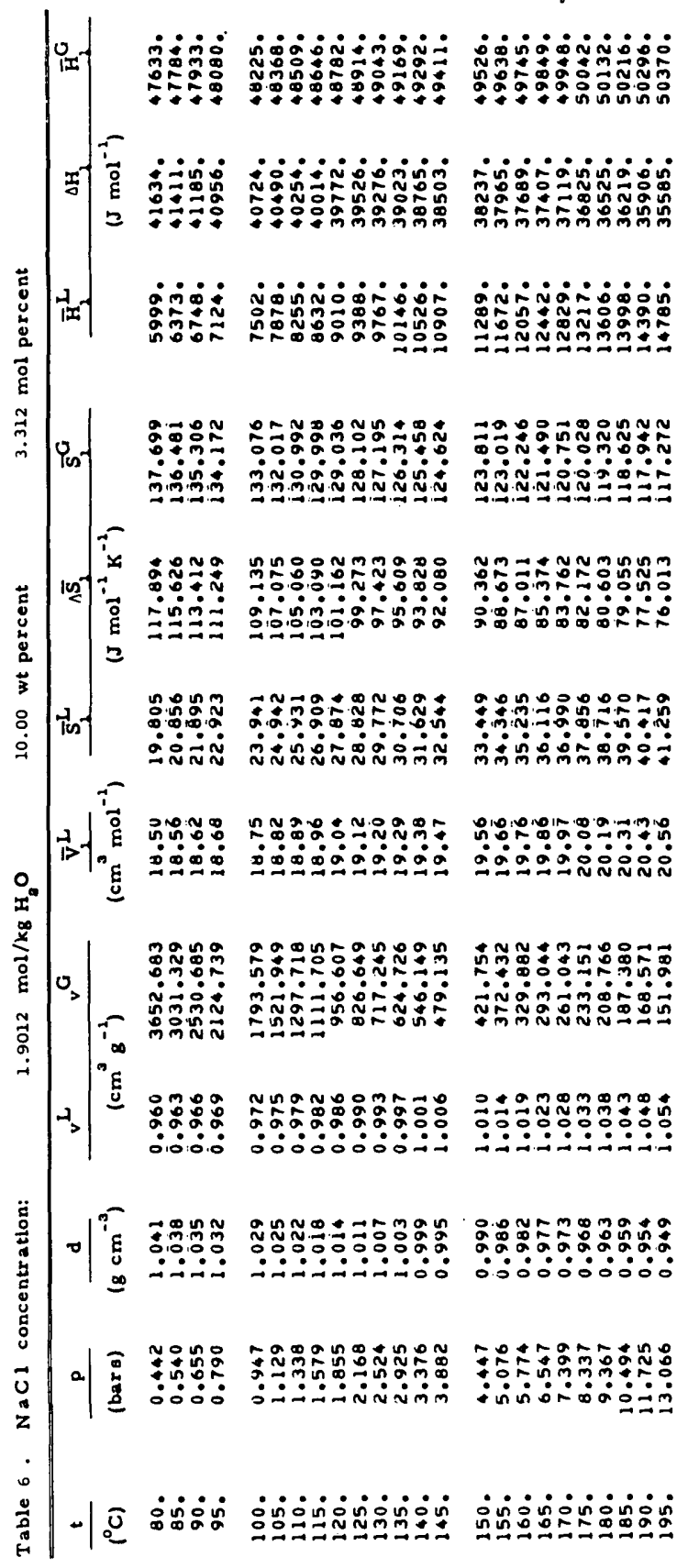



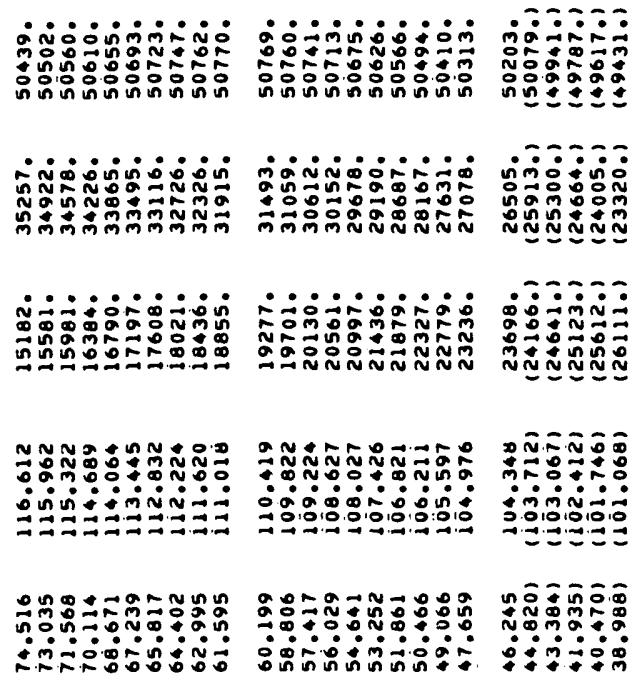

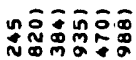

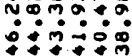

- - -

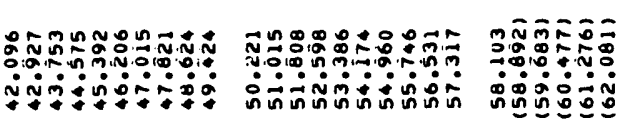

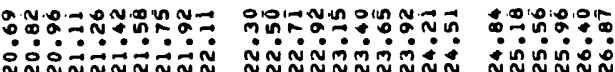

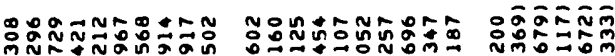

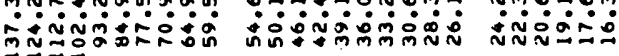
(2)

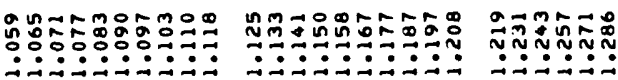

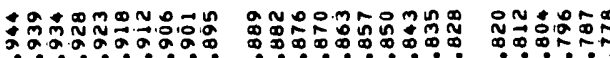
00000000 000000:00 :00000

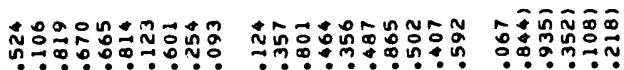

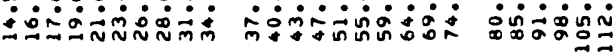

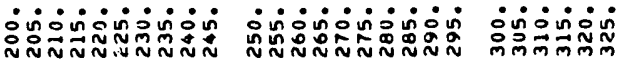




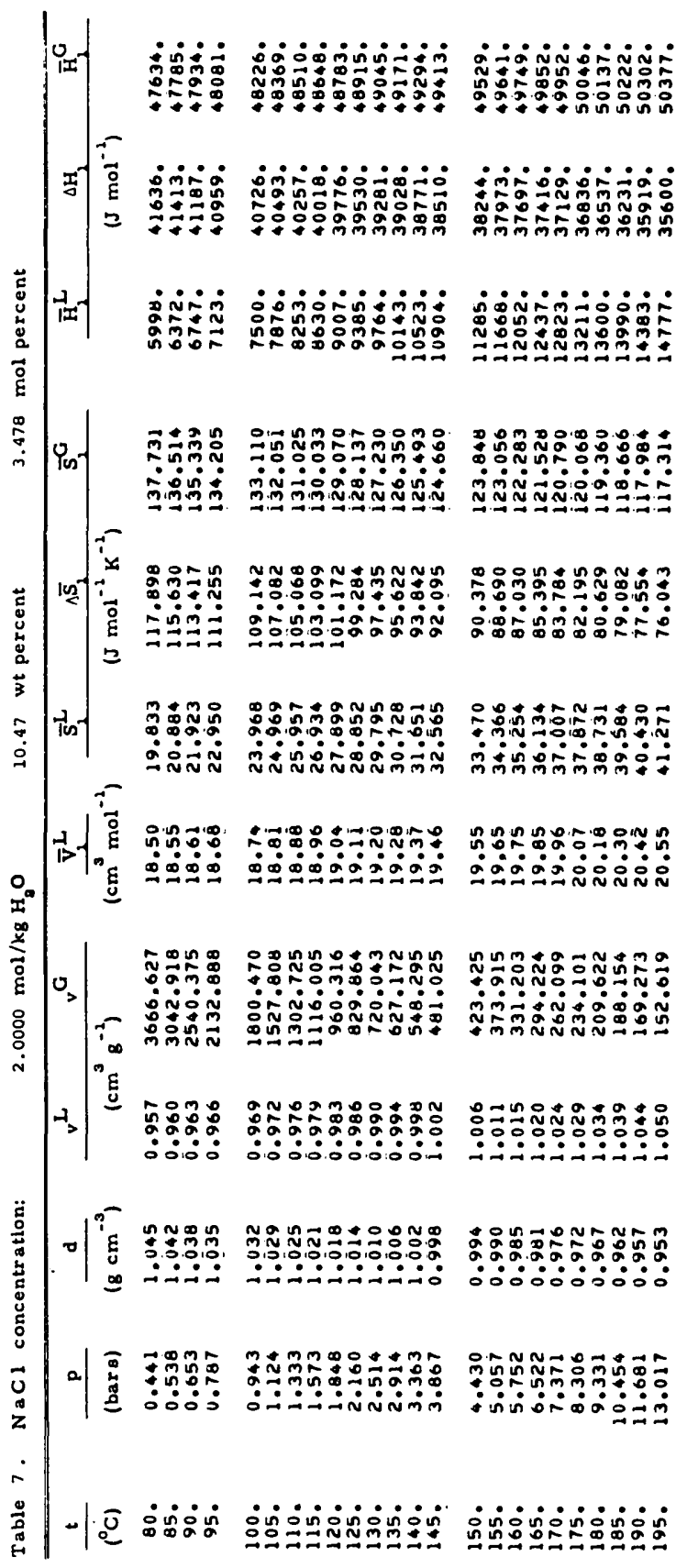



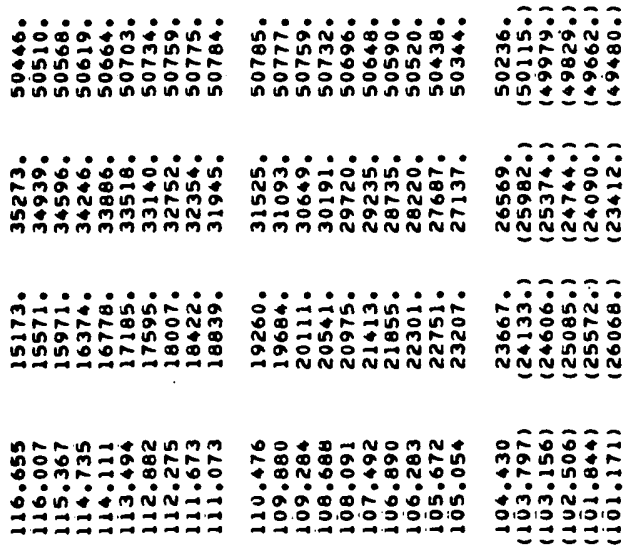

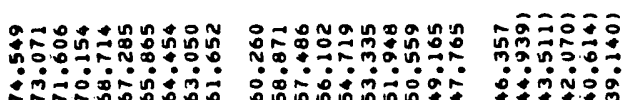

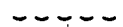

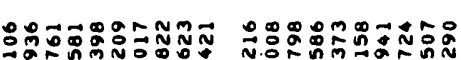

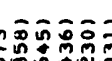

*

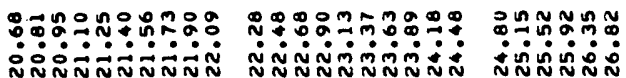

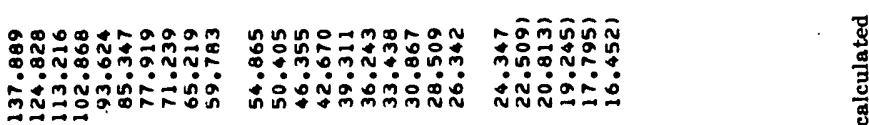

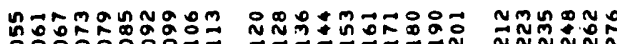

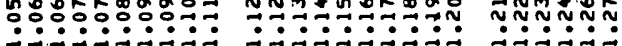

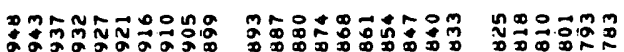

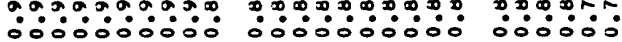

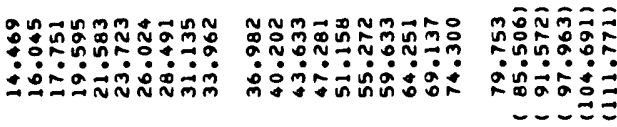

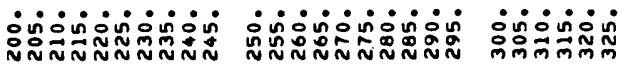




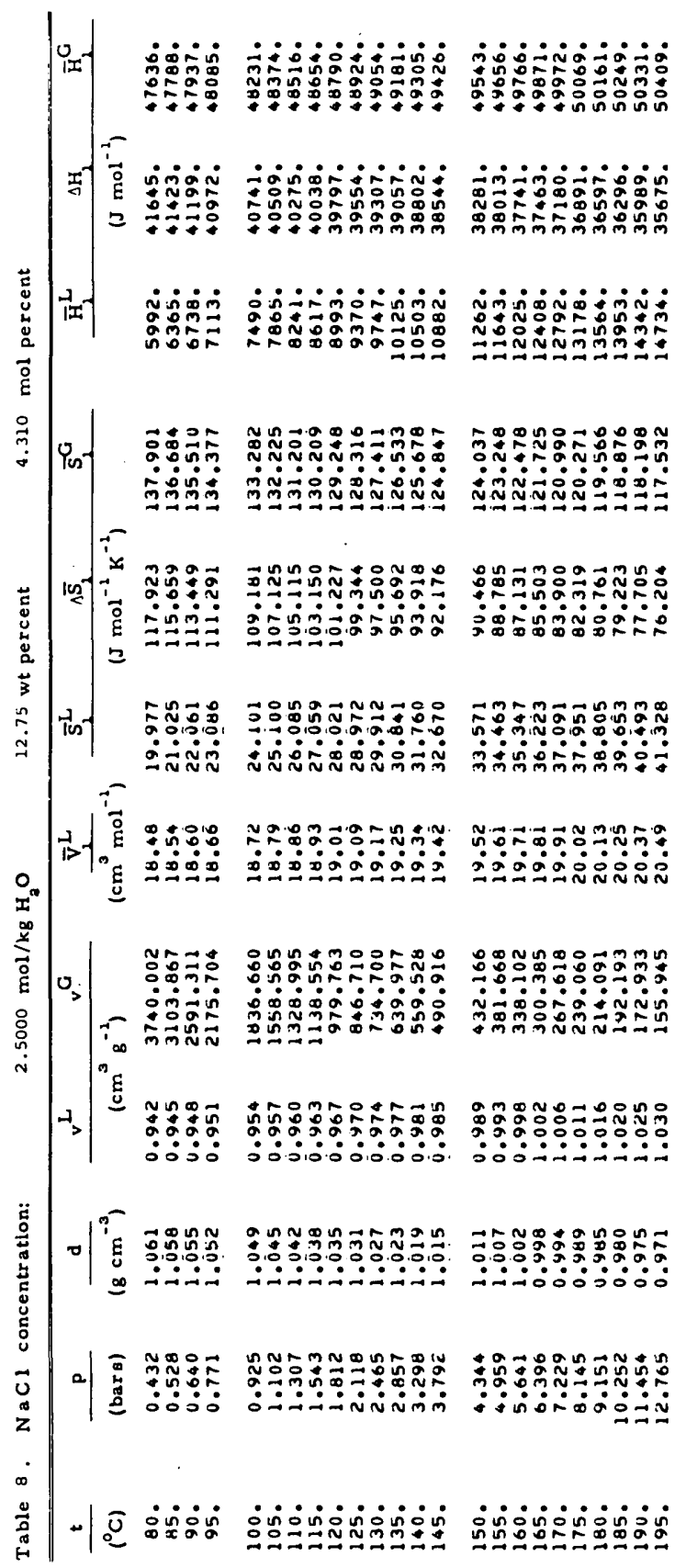



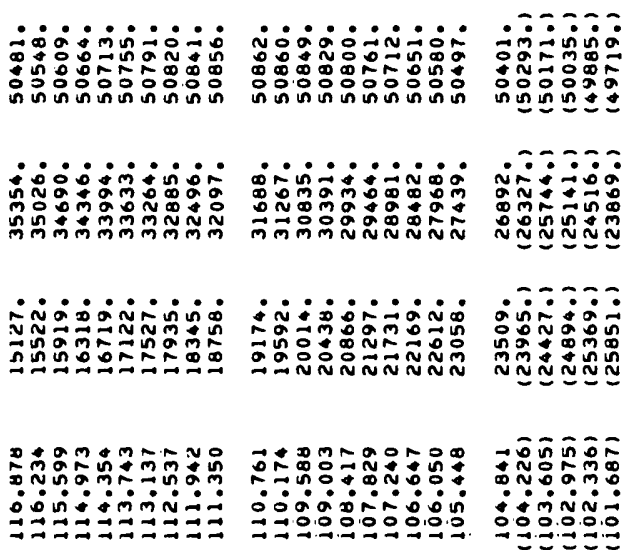

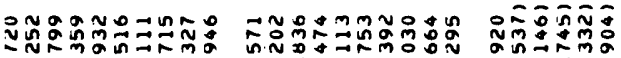

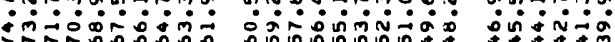

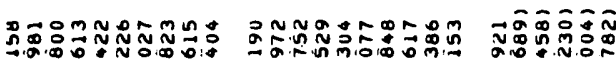
-

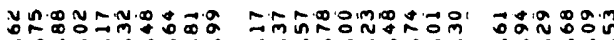

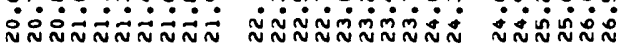

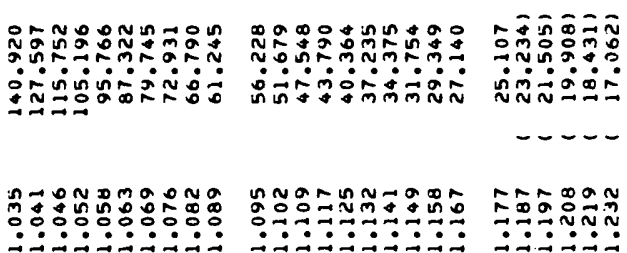

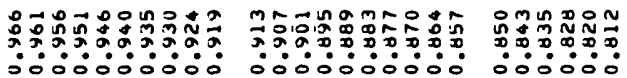

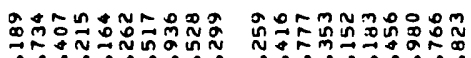

mลิ์

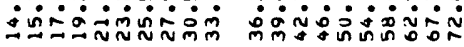

-

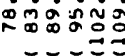

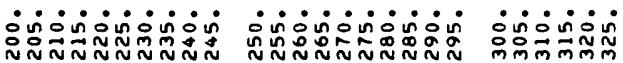




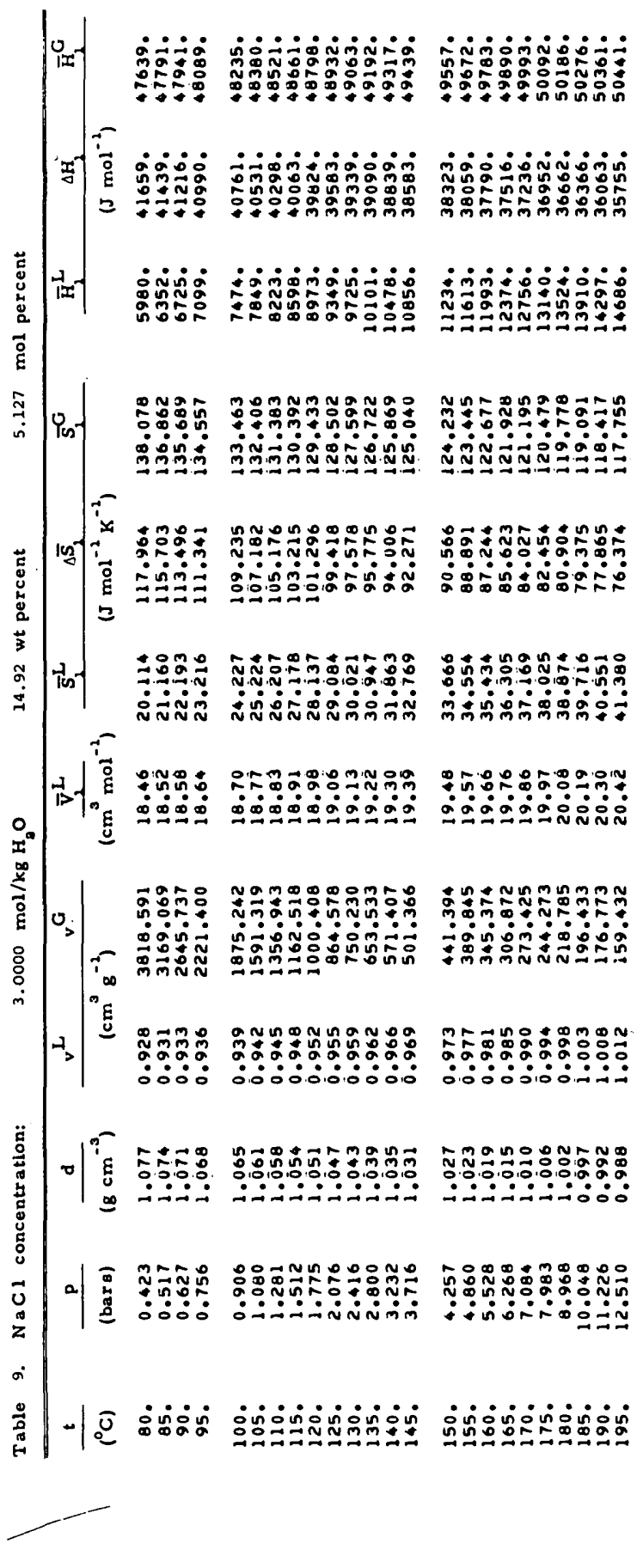




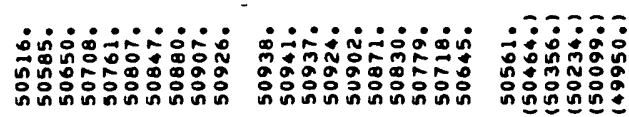

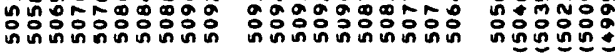

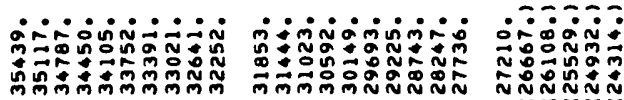

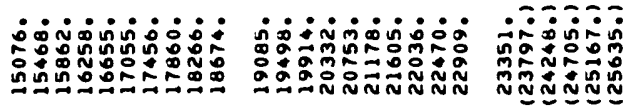

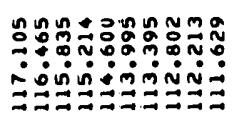

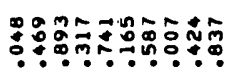

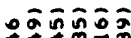

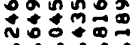

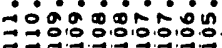
no:

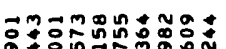

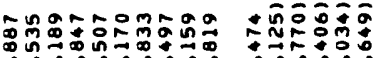

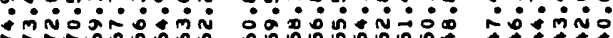

- - -

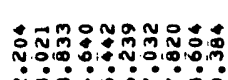

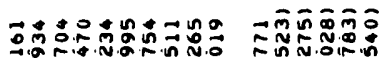

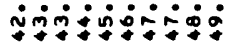

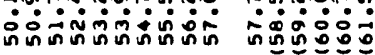

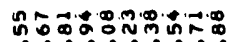

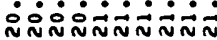

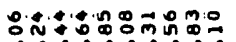

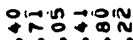

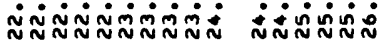

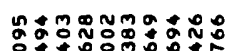
$\therefore \dot{0} \dot{0} 0: \dot{0}$

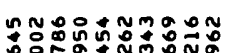

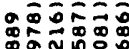
คिं்-

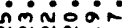

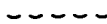

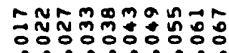

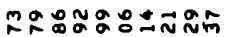

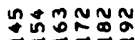

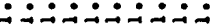
$\because: 0: \because \because \because \div \div$

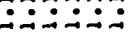

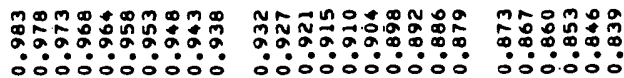

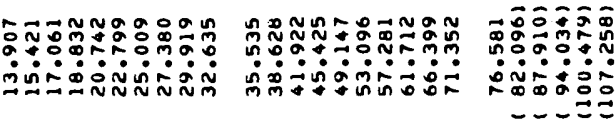

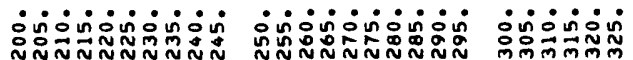




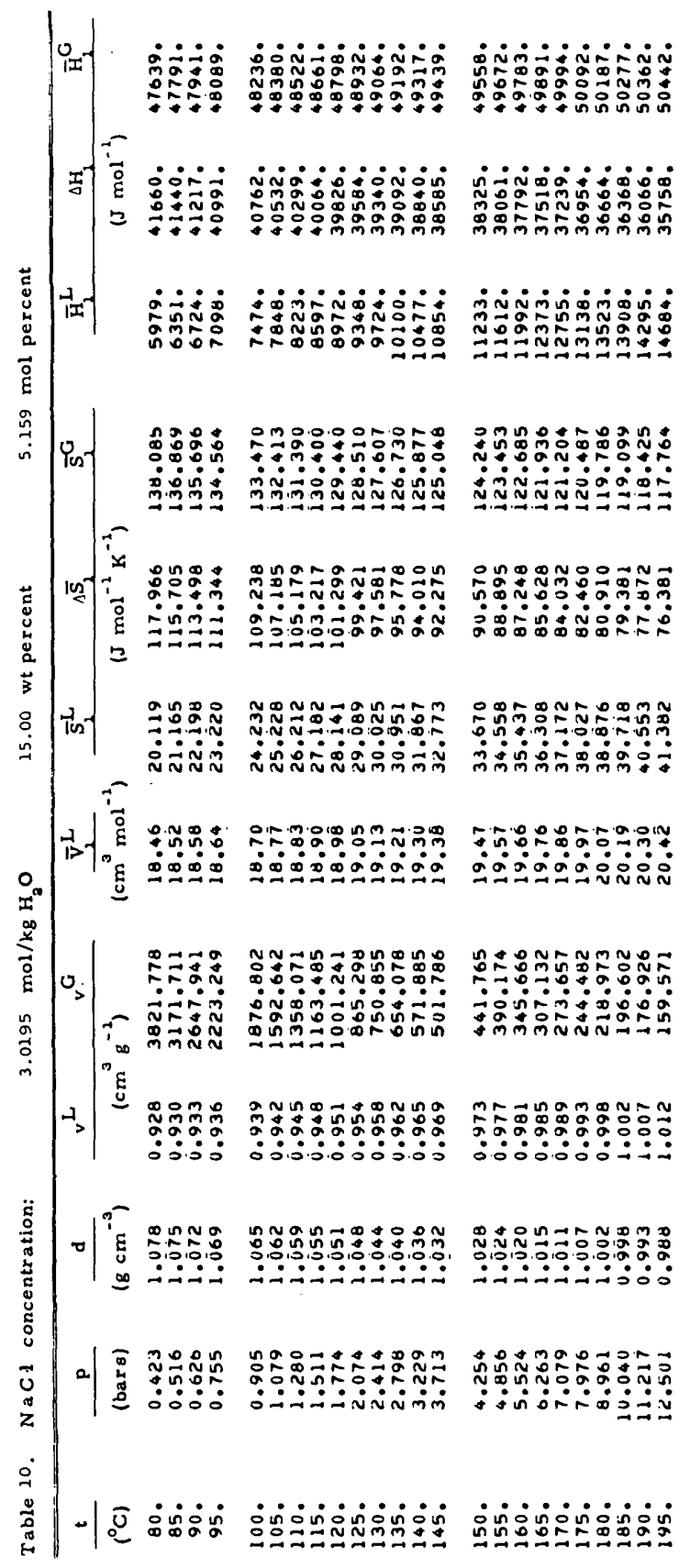




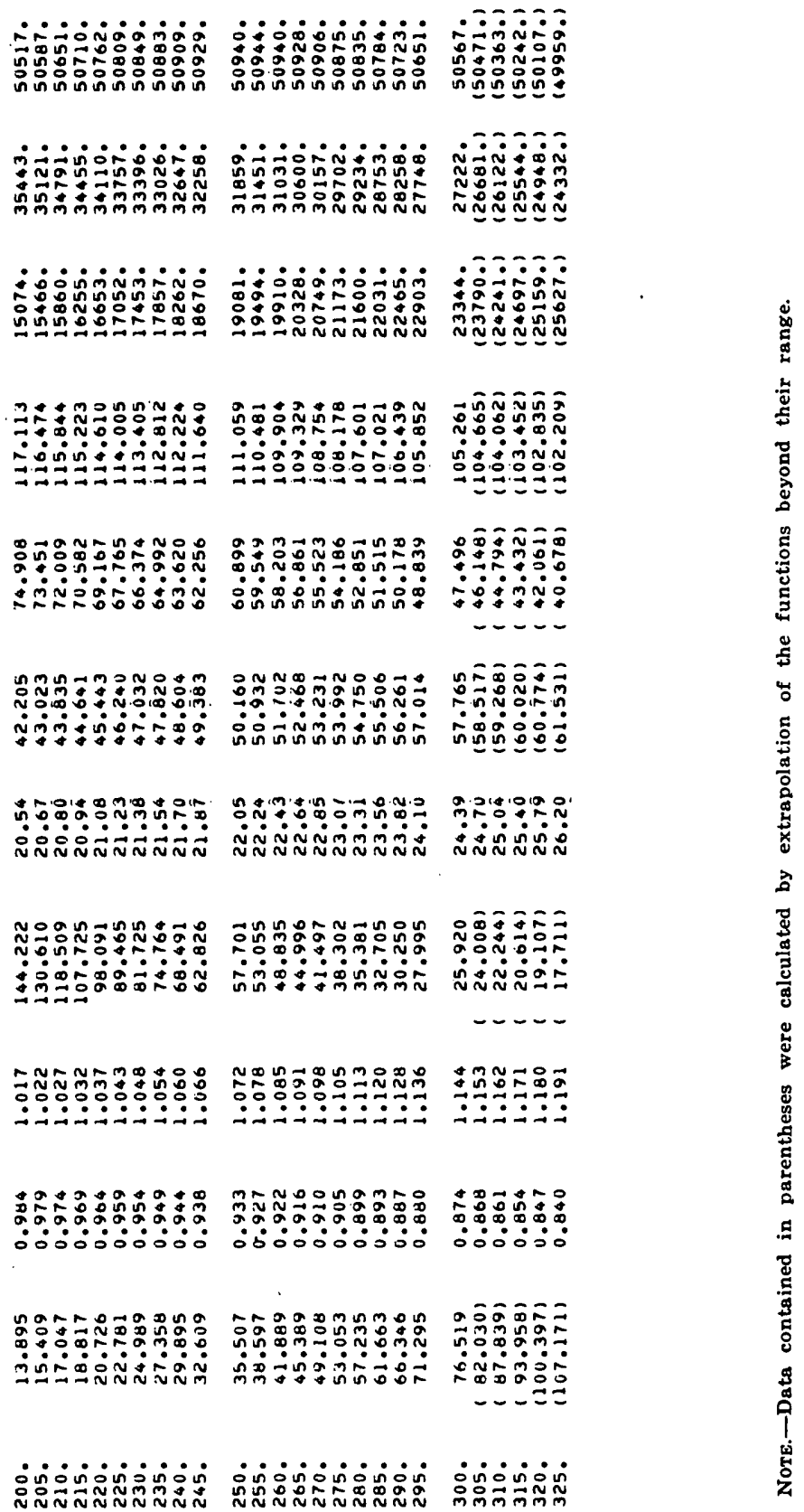




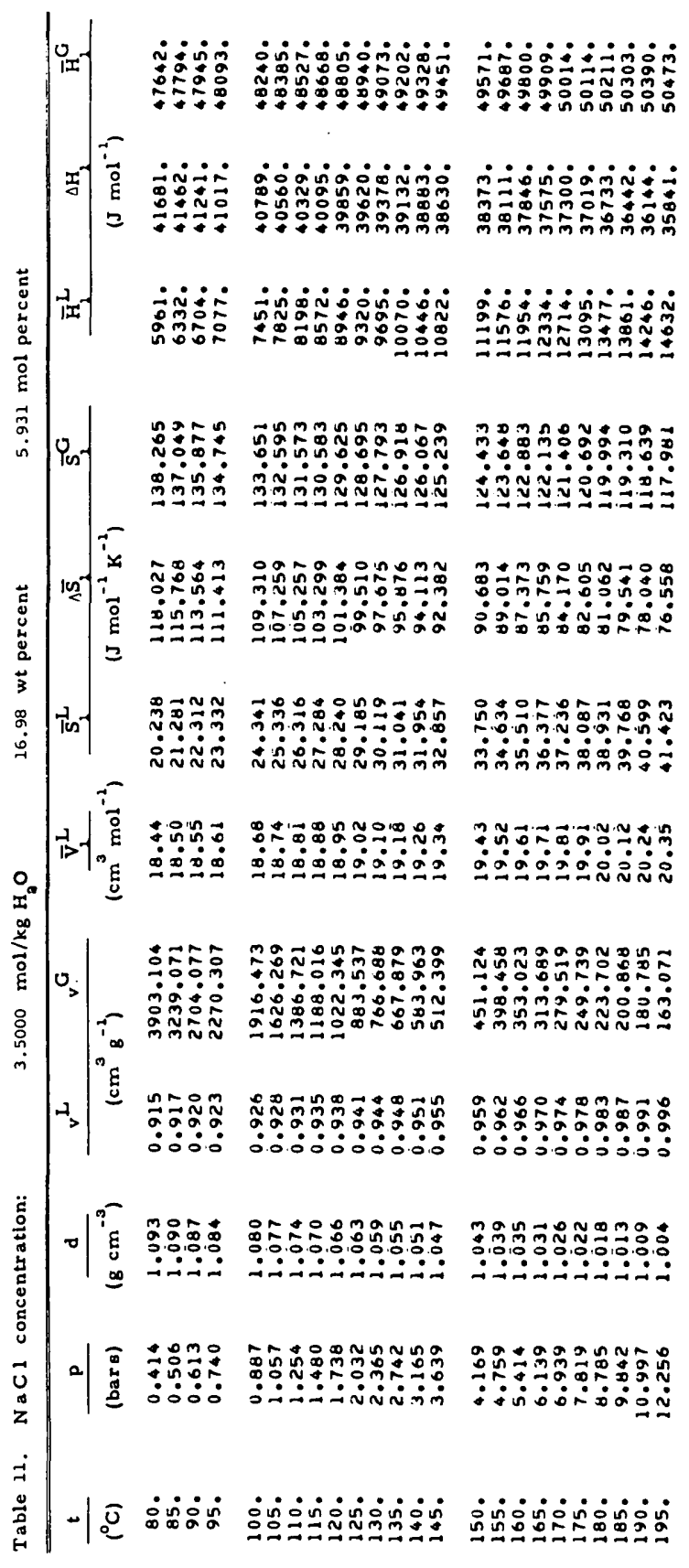




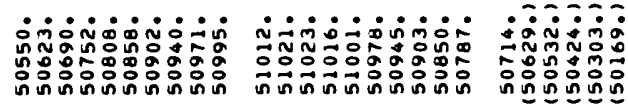

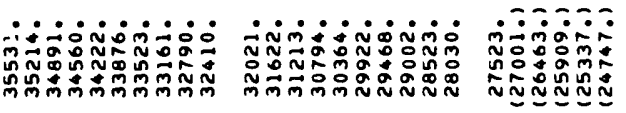

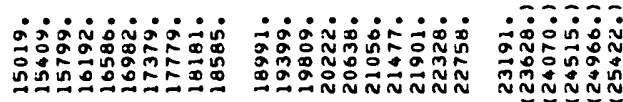

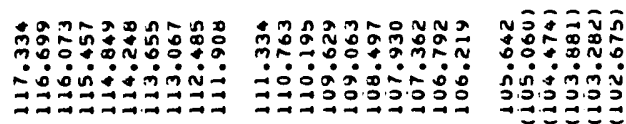

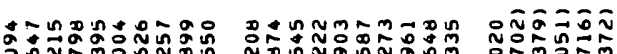
วดท.บำ

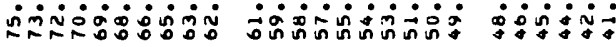

- -

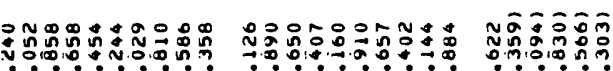

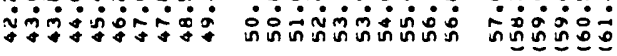

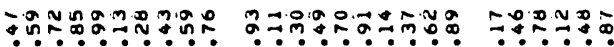

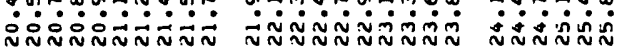

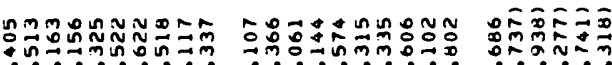

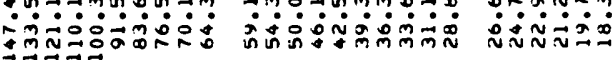

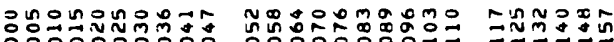

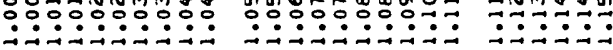

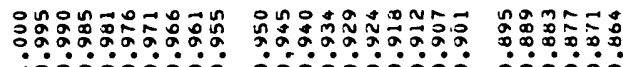

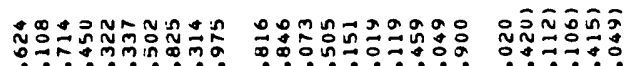

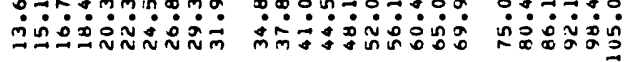

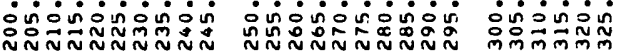




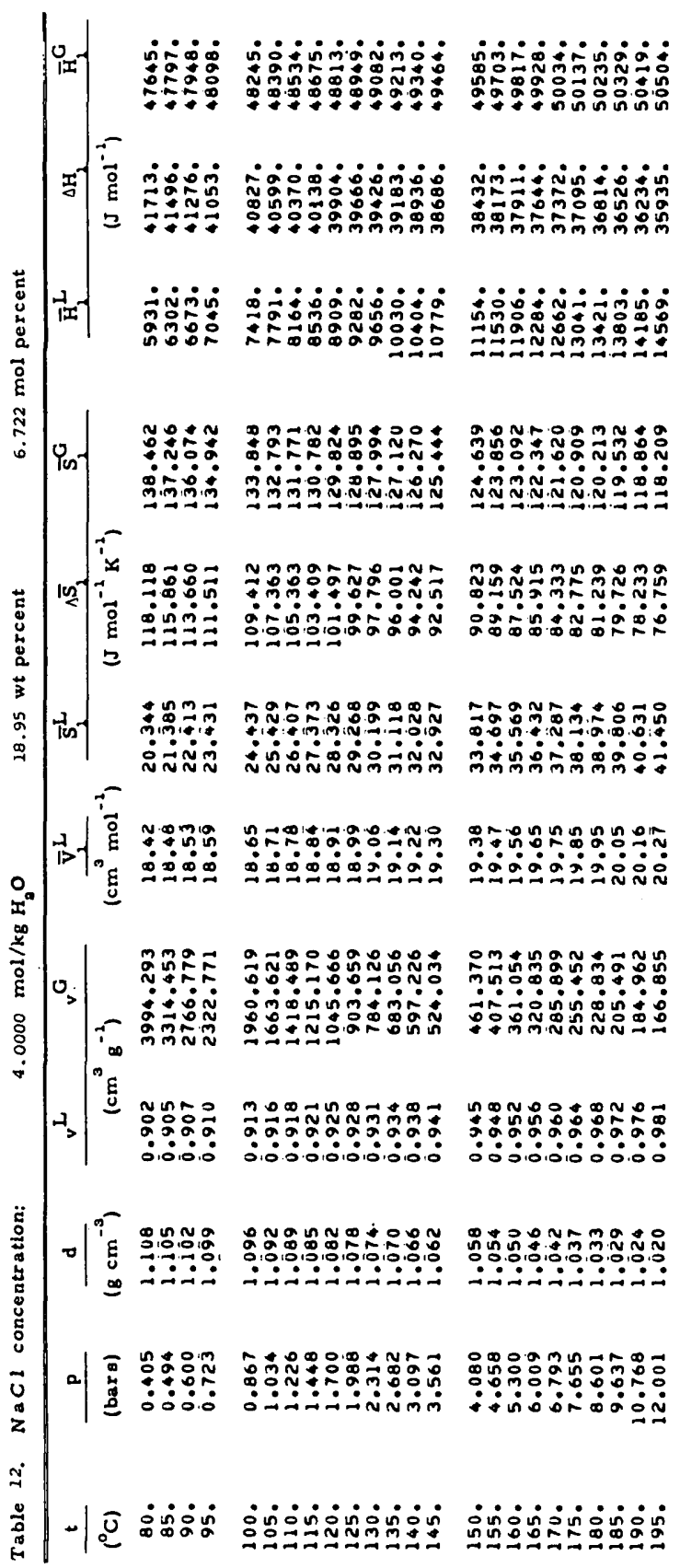




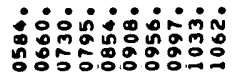
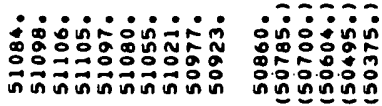

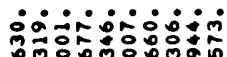

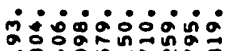

ํํํำ

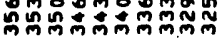

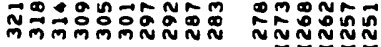

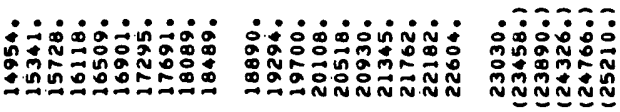

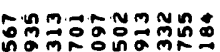

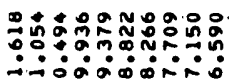

บำ

ióniniminis

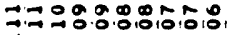

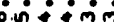

oigioiolo

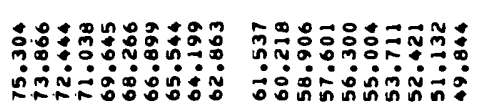

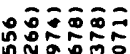

กูก.ำ

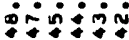

- -

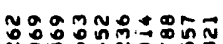

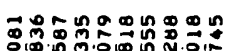

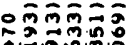

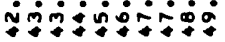

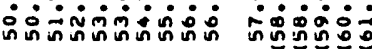

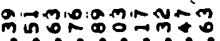

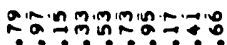

Non $\overrightarrow{0} \div$ in

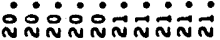

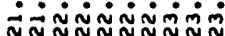

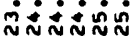

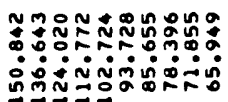

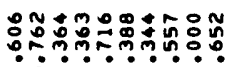

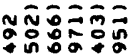

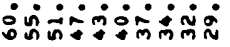

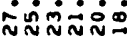

- - -

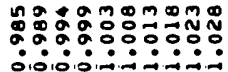

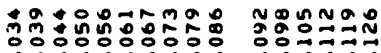

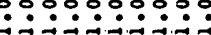

$\because \div \div \div$

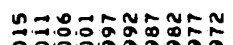

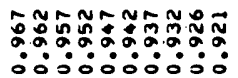

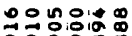

$\because \because \therefore \therefore 00000$

$\because 000^{\circ}$

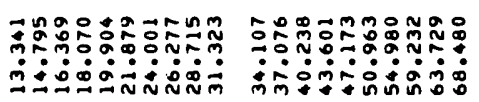

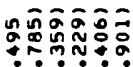

$\because \div \div \dot{0}$

ㄴー二

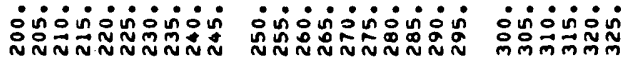

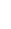

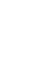




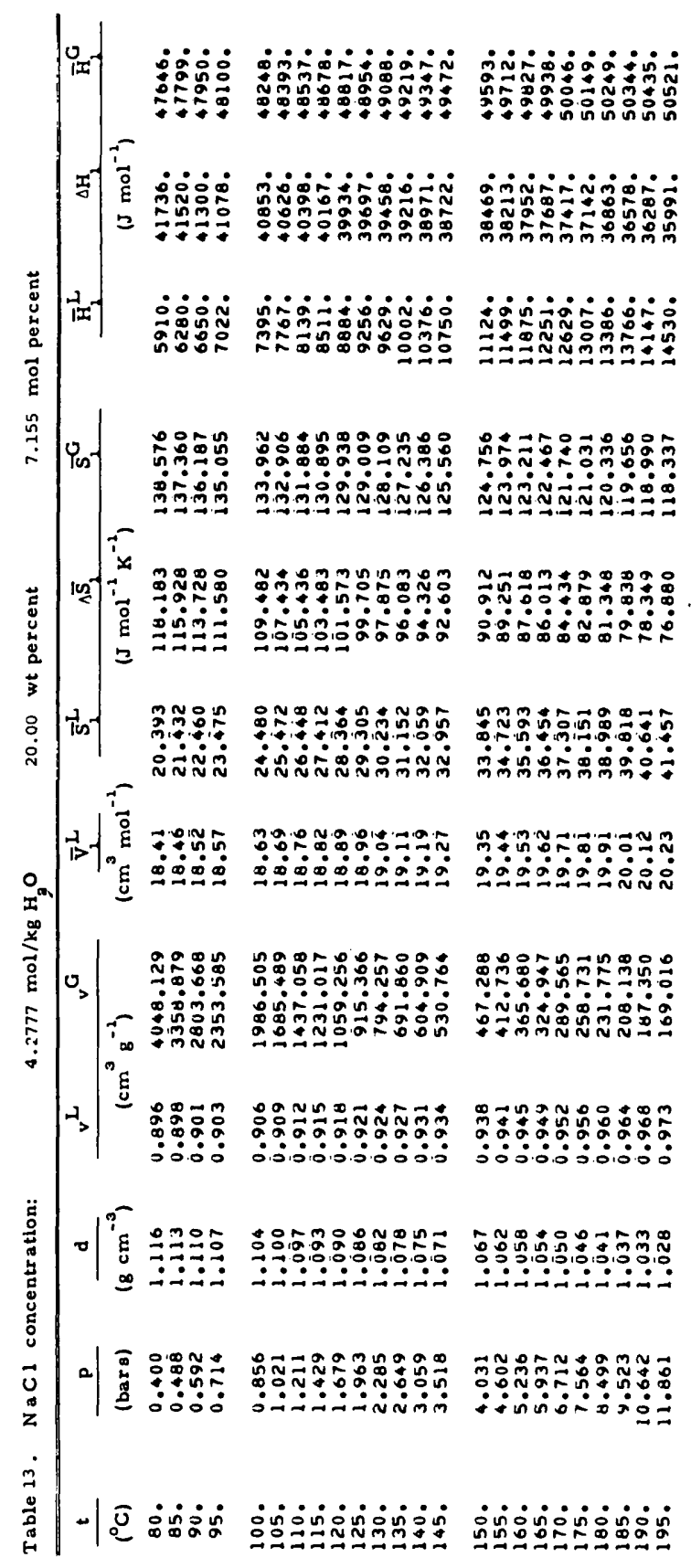



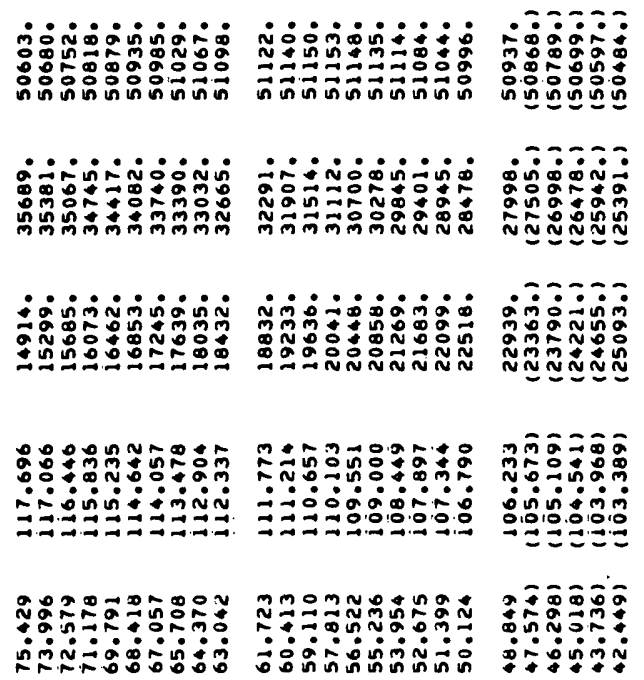

กับ

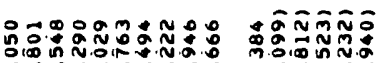

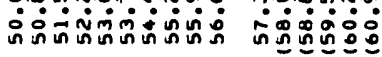

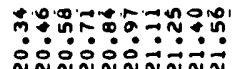

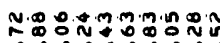

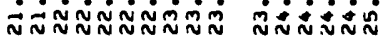

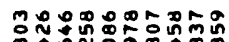

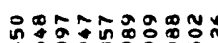

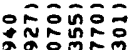
जिं ด

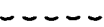

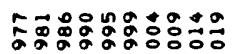

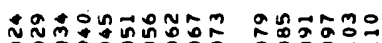
अ000100

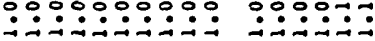

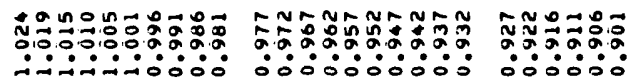

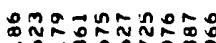

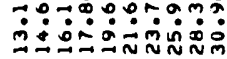

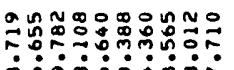

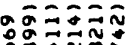

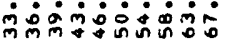

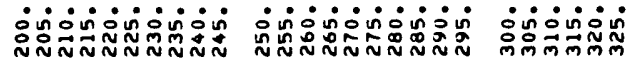




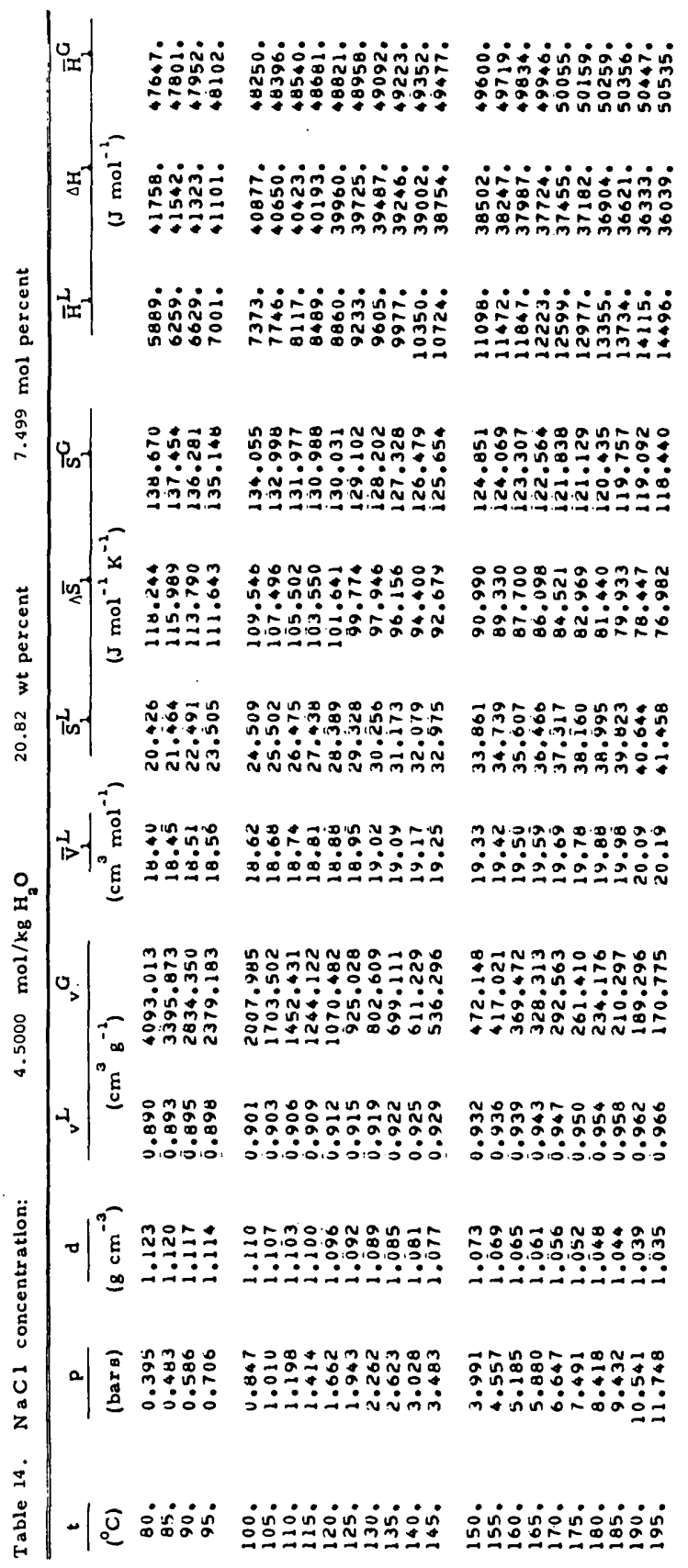




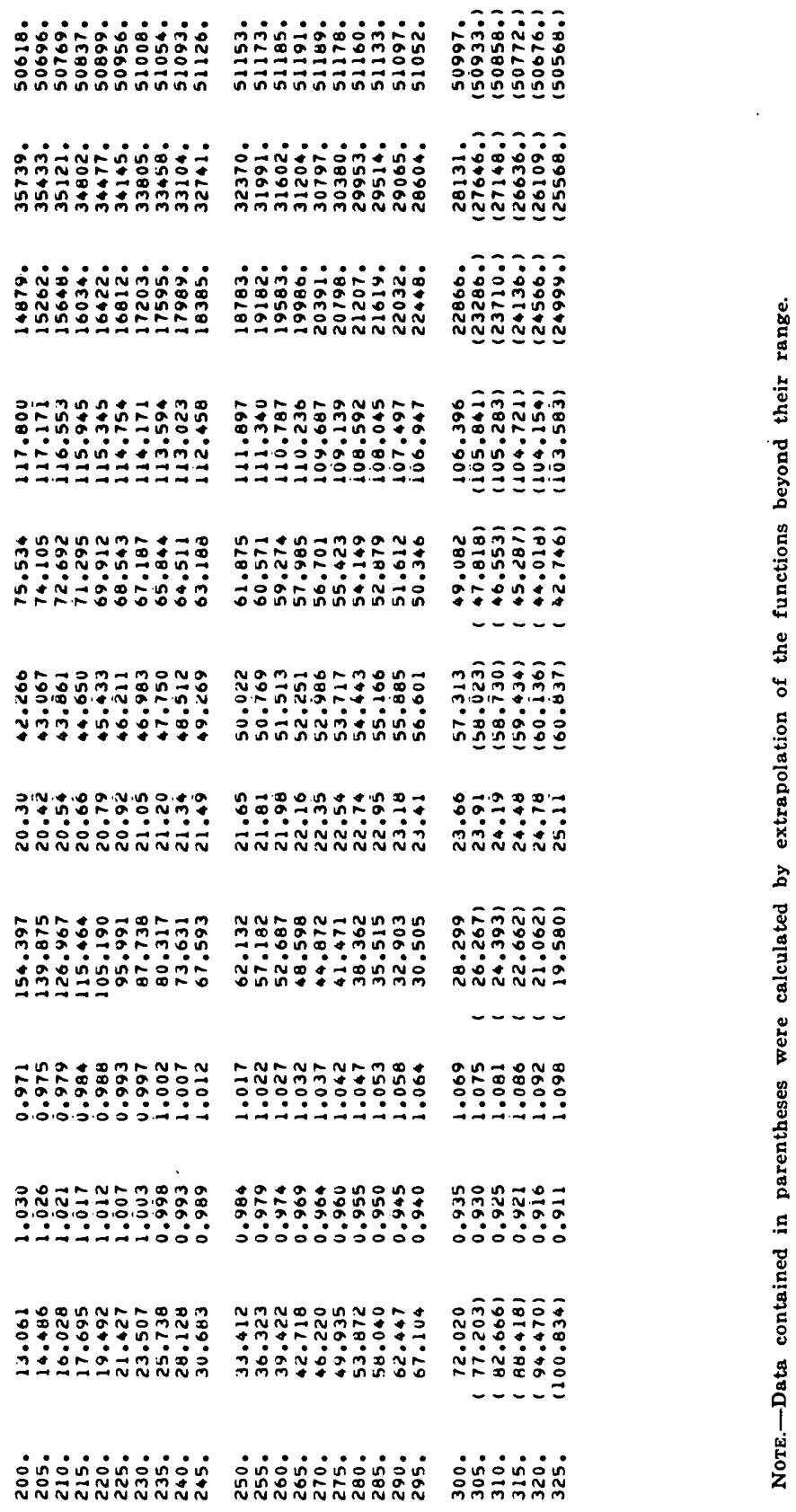




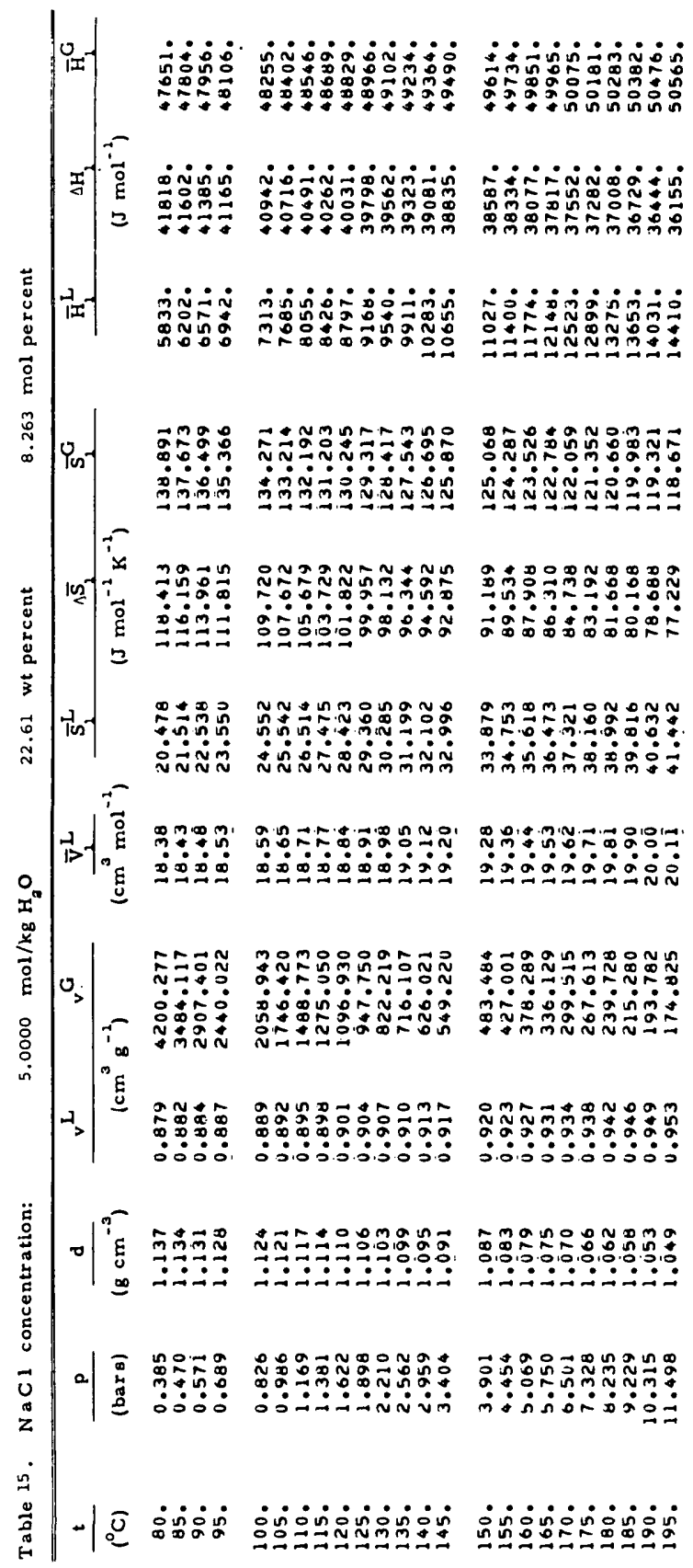




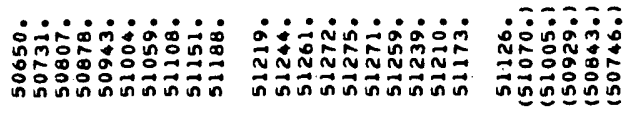

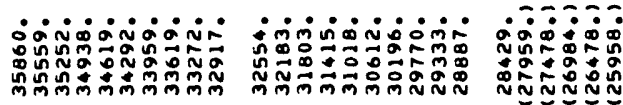

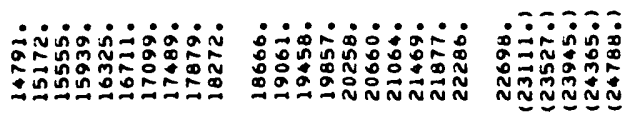

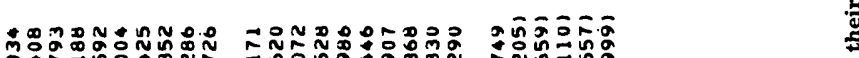

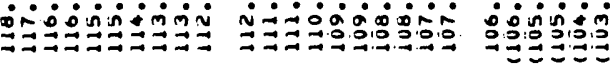

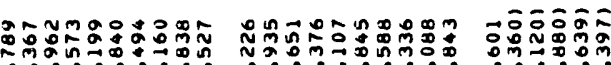

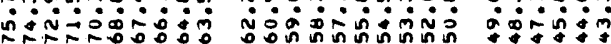

(1)

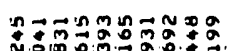

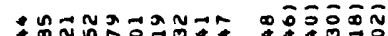

$\because \cos 20$

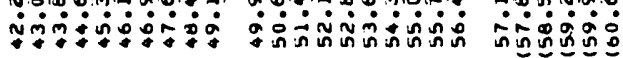

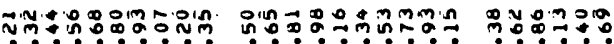

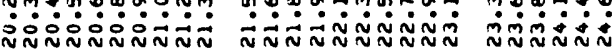

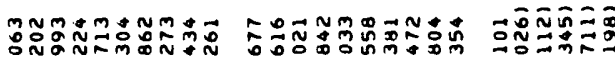

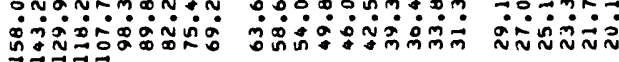

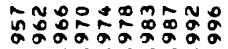

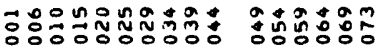

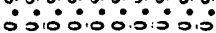

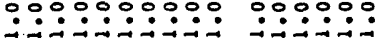

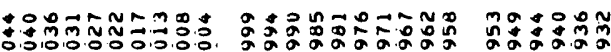

-

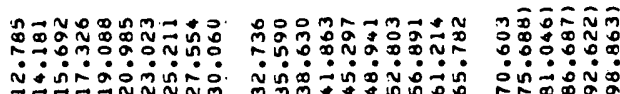

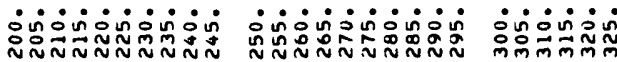




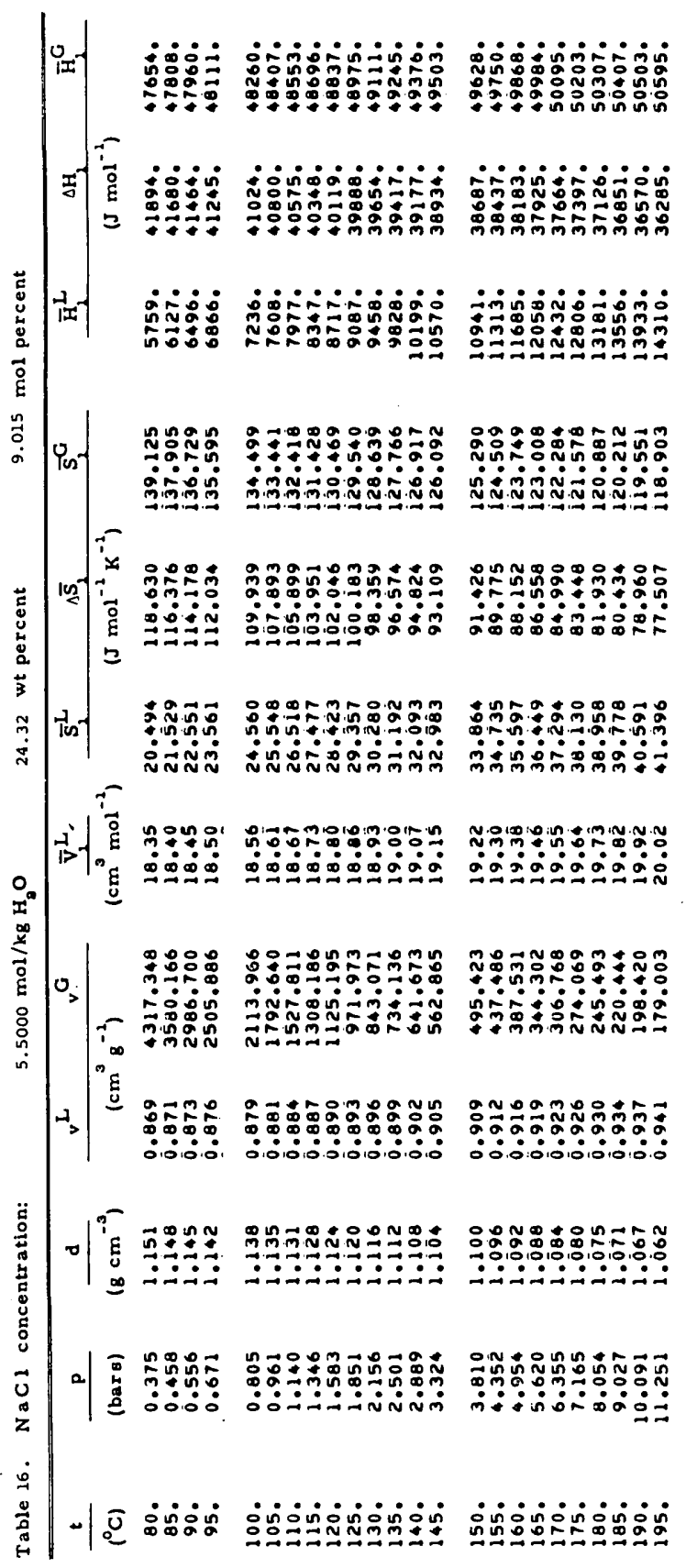




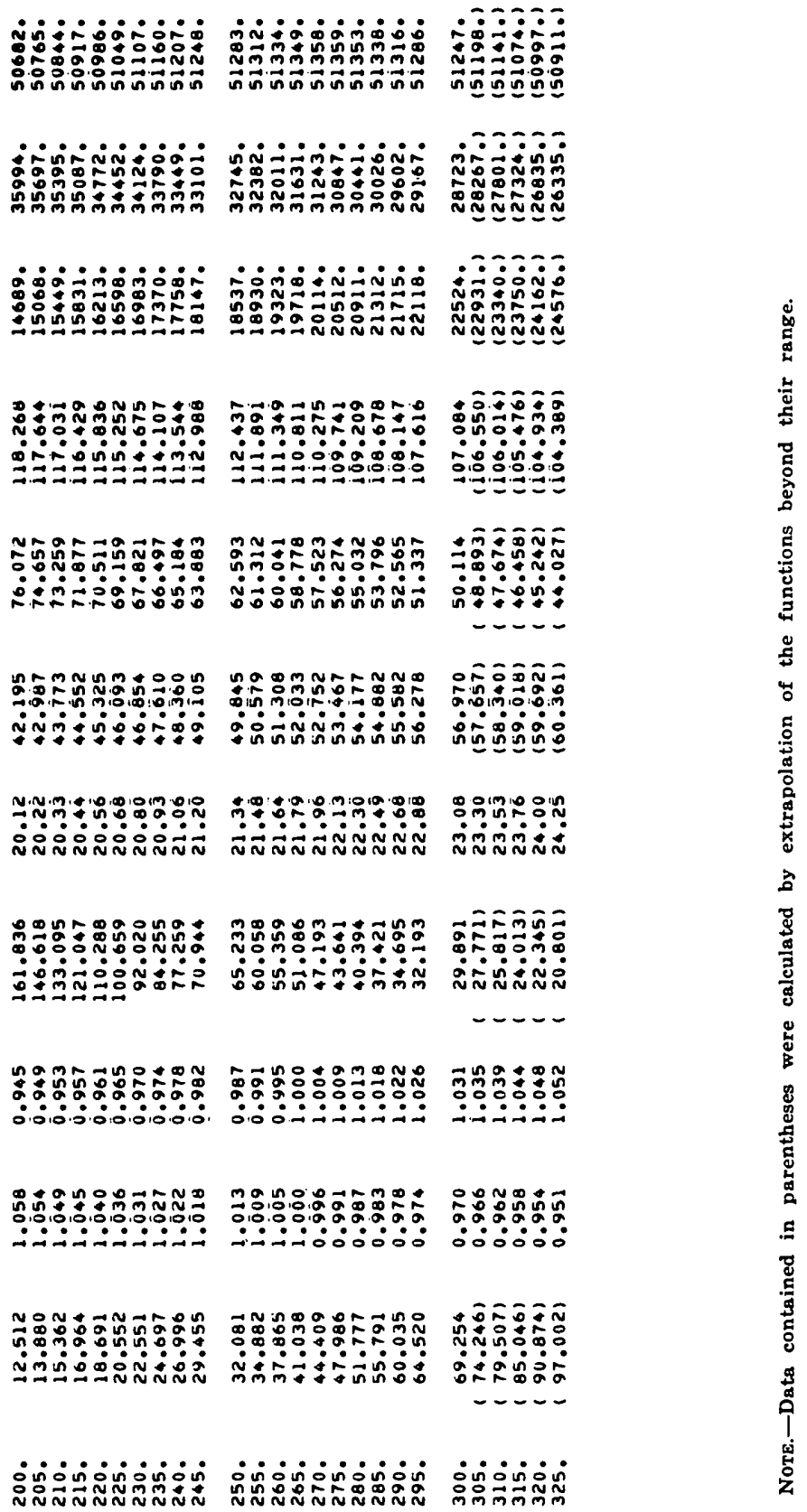




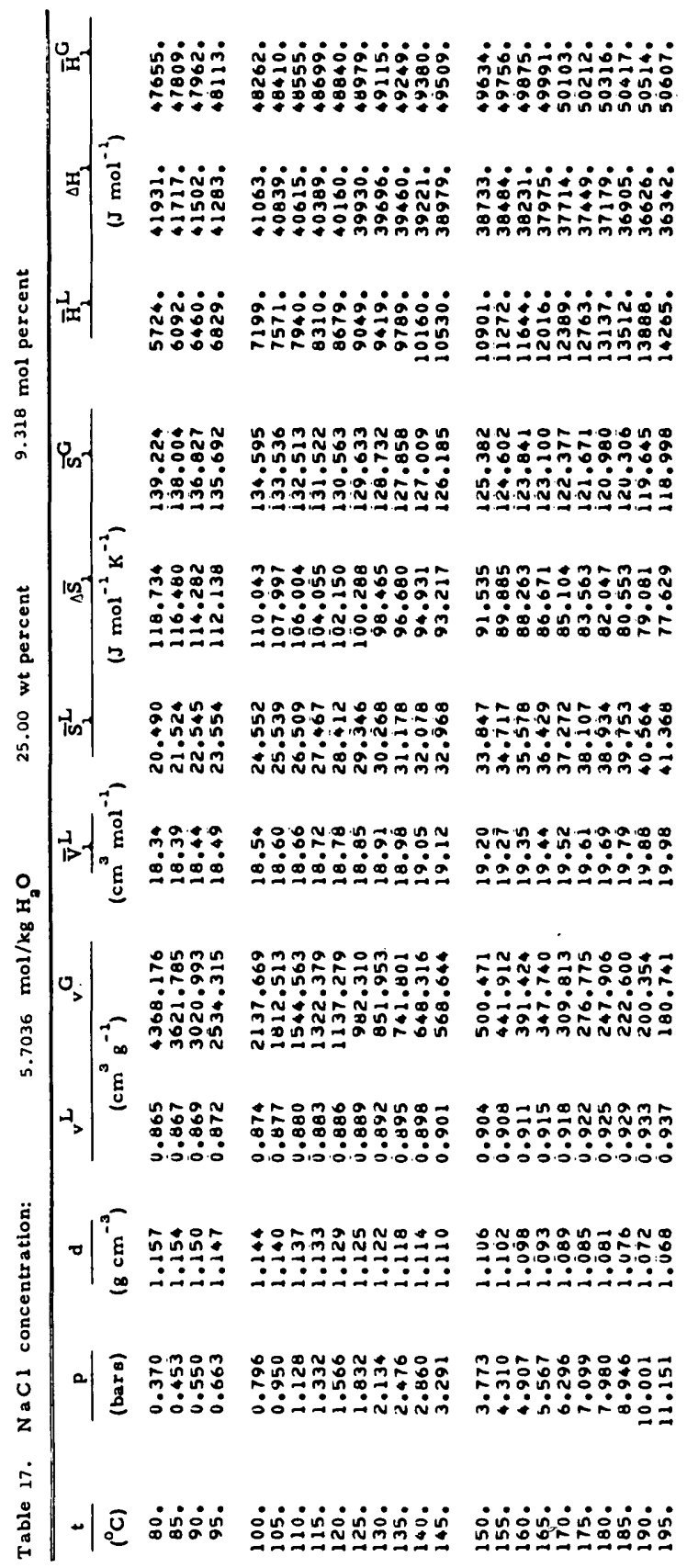



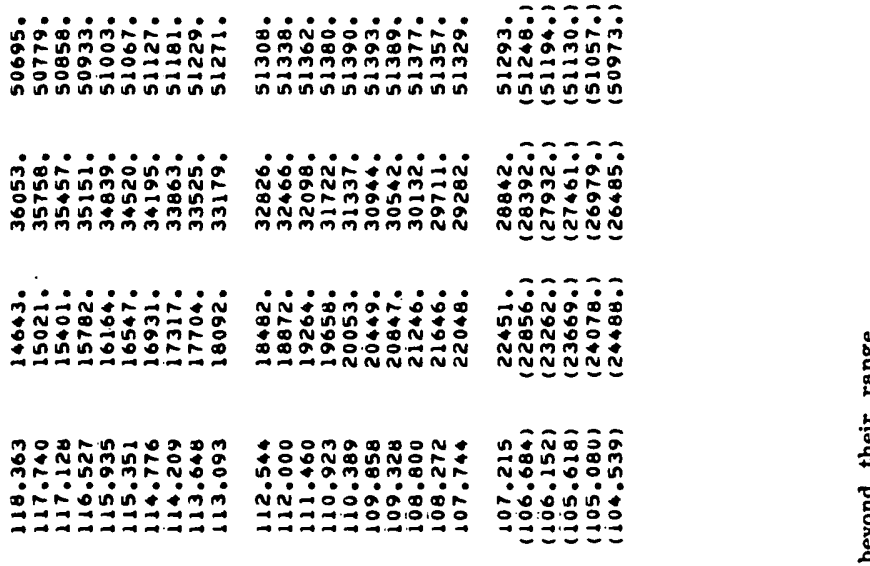

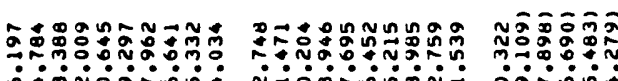

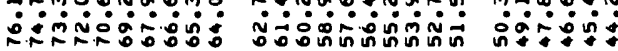

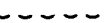

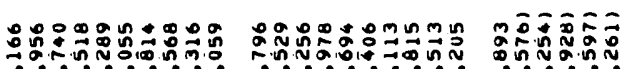
+

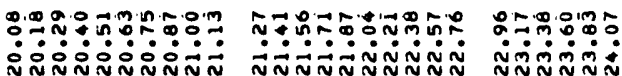

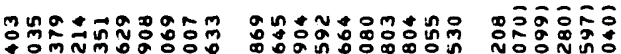
मीN

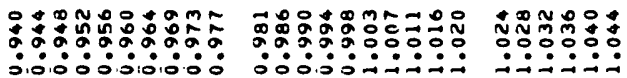

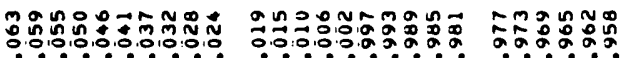
-

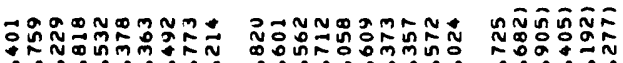

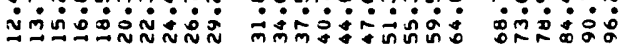

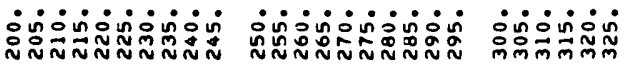




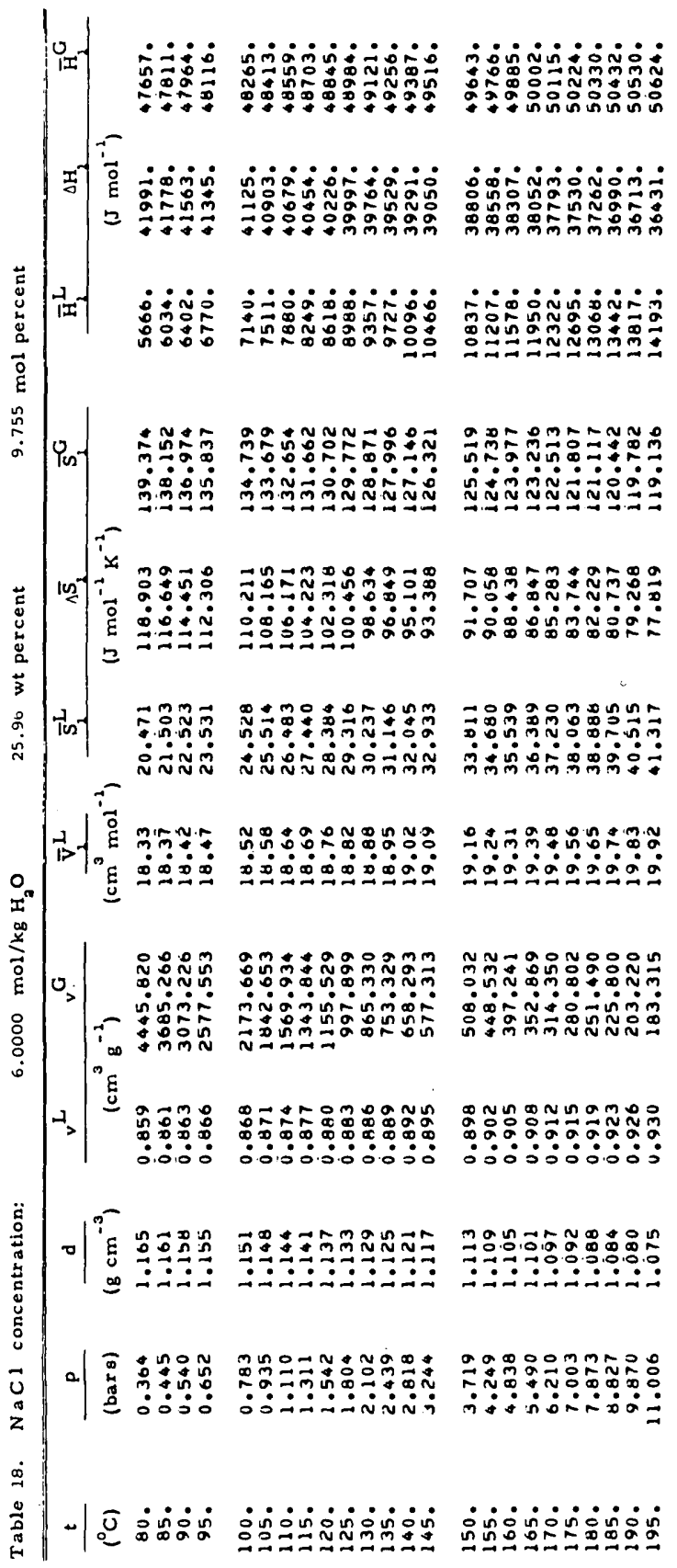




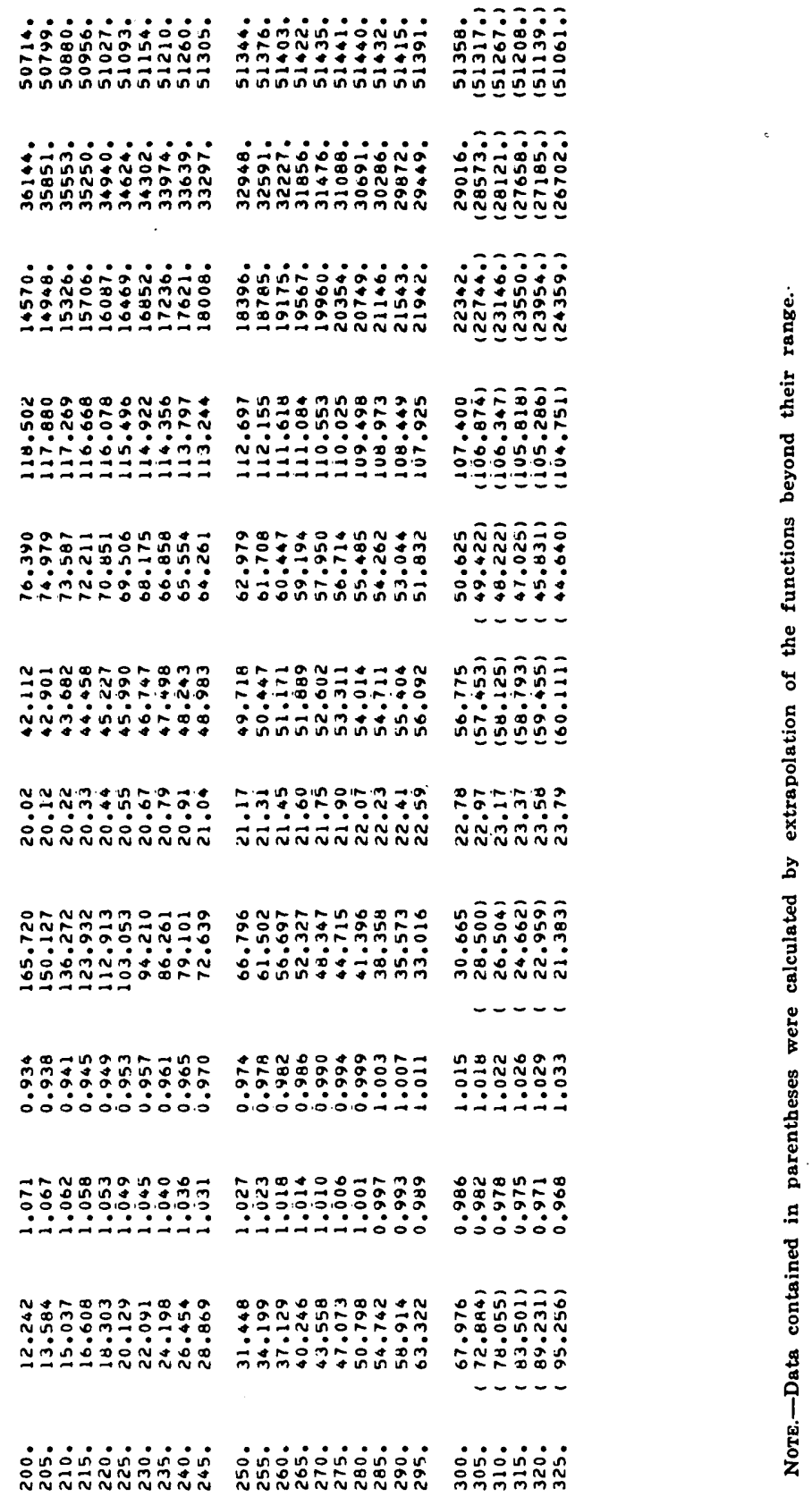




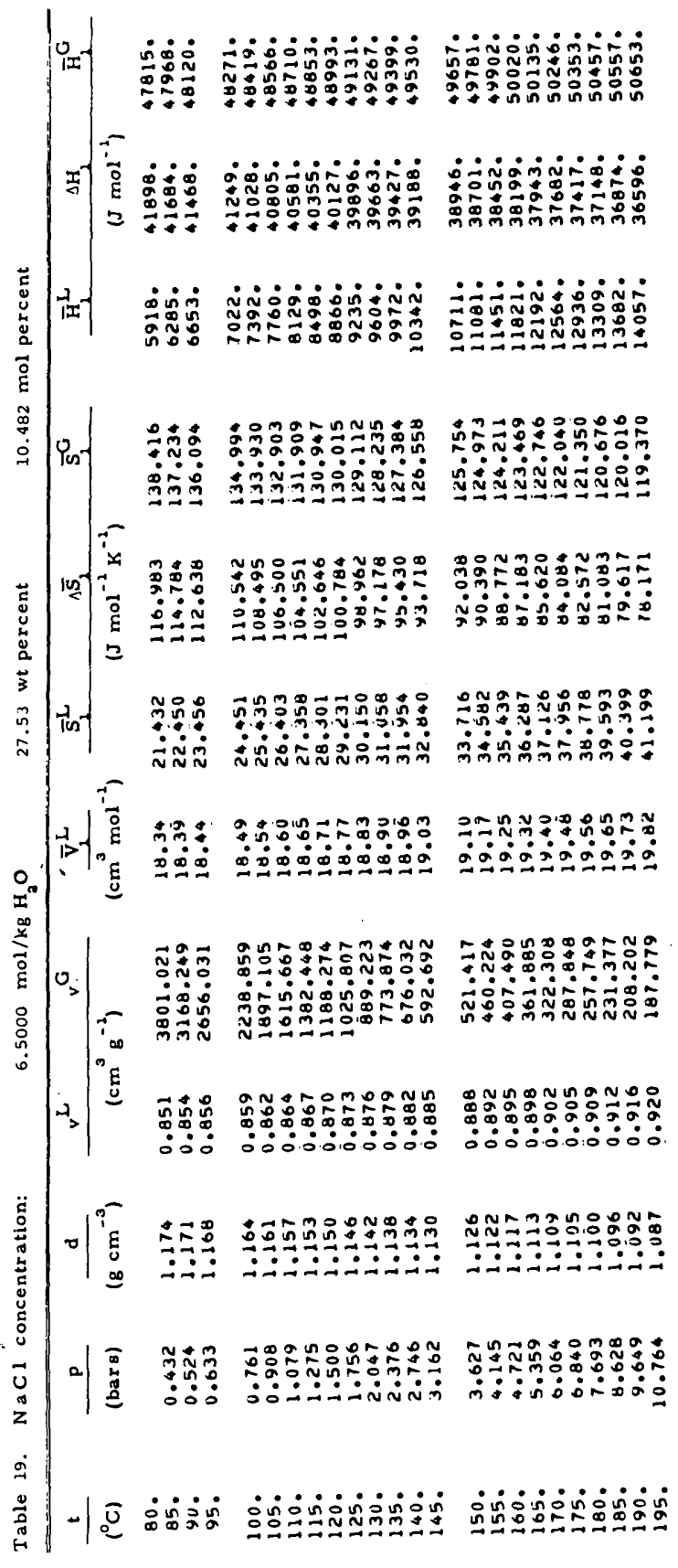




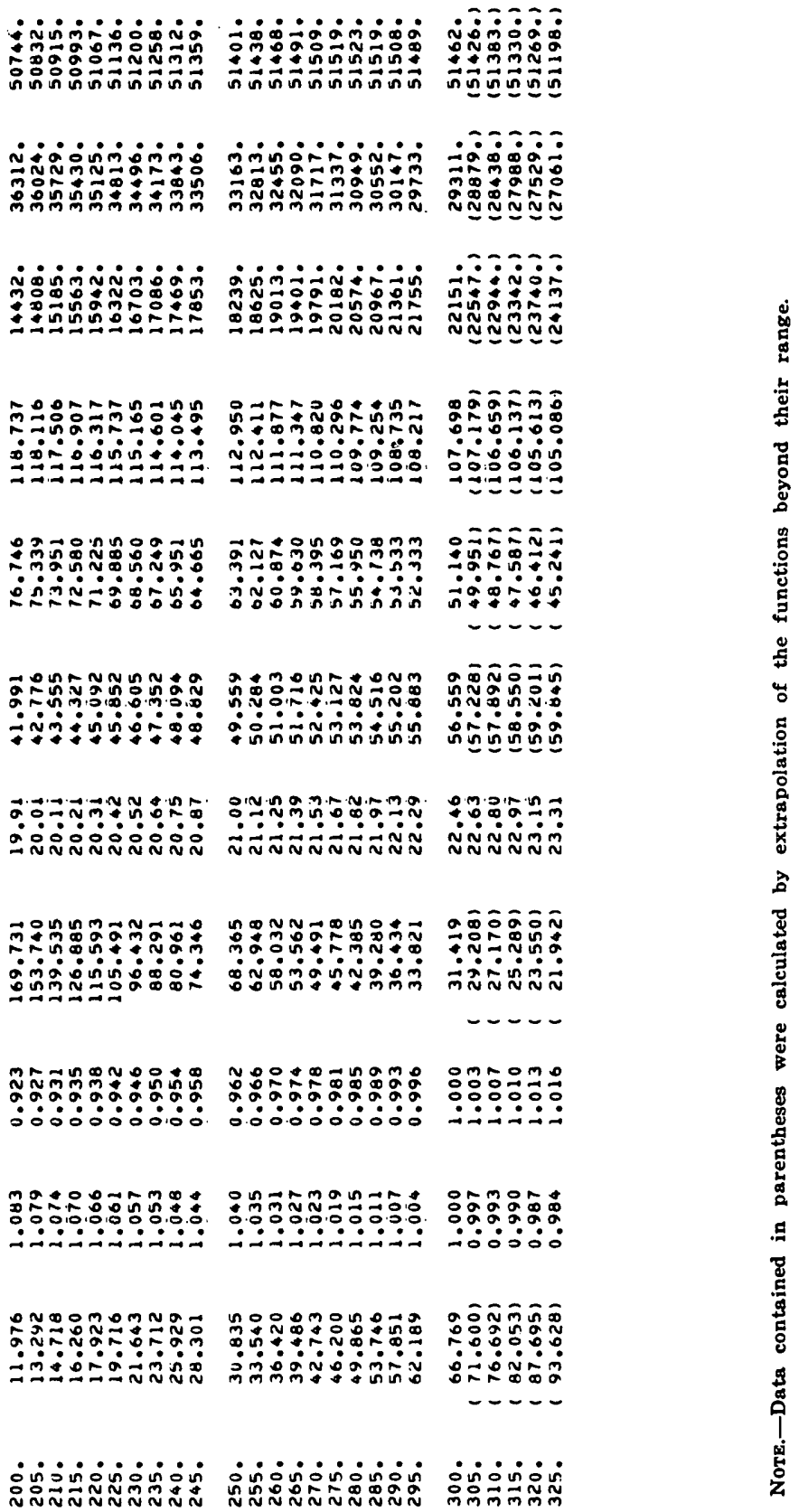




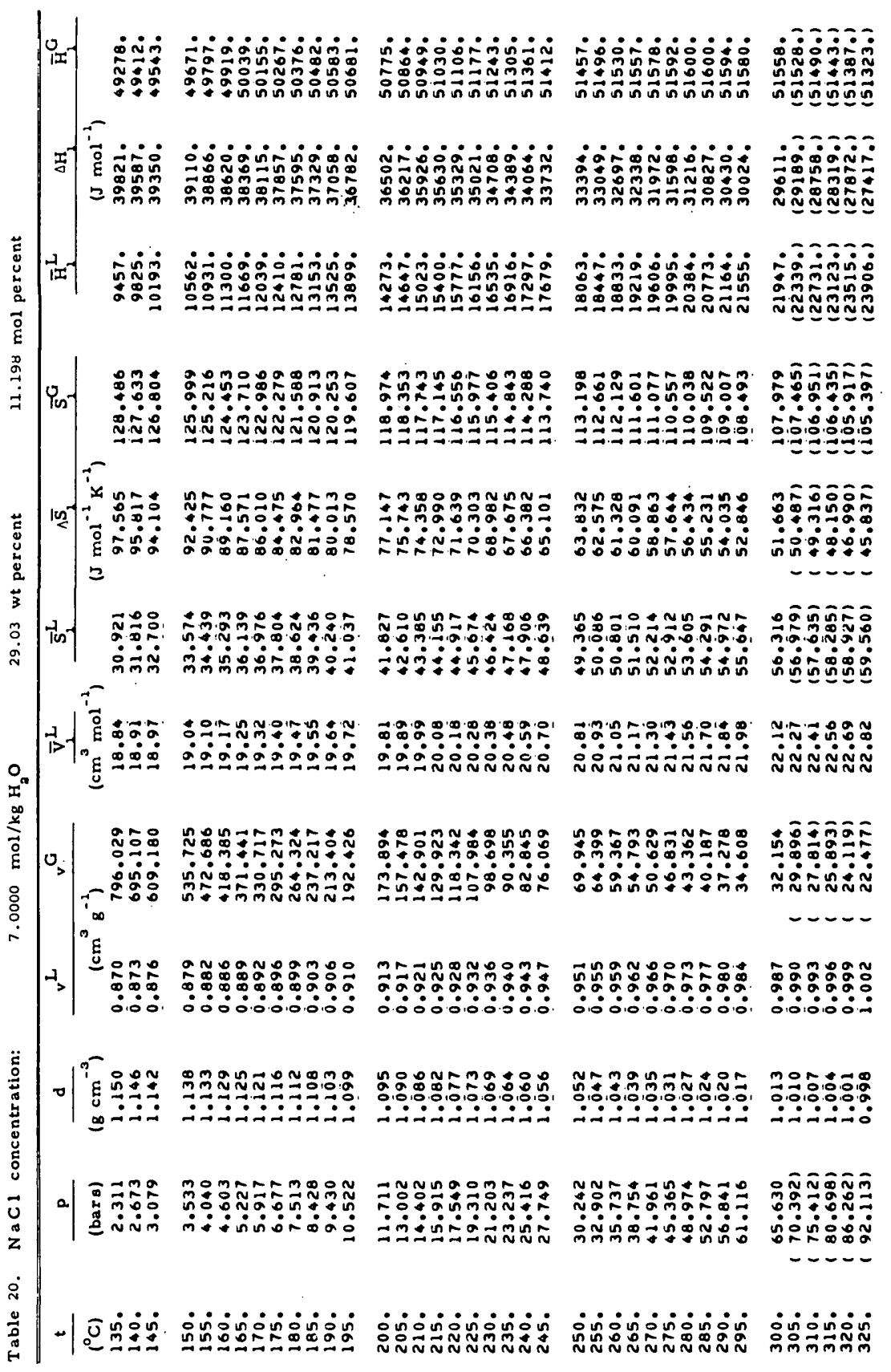




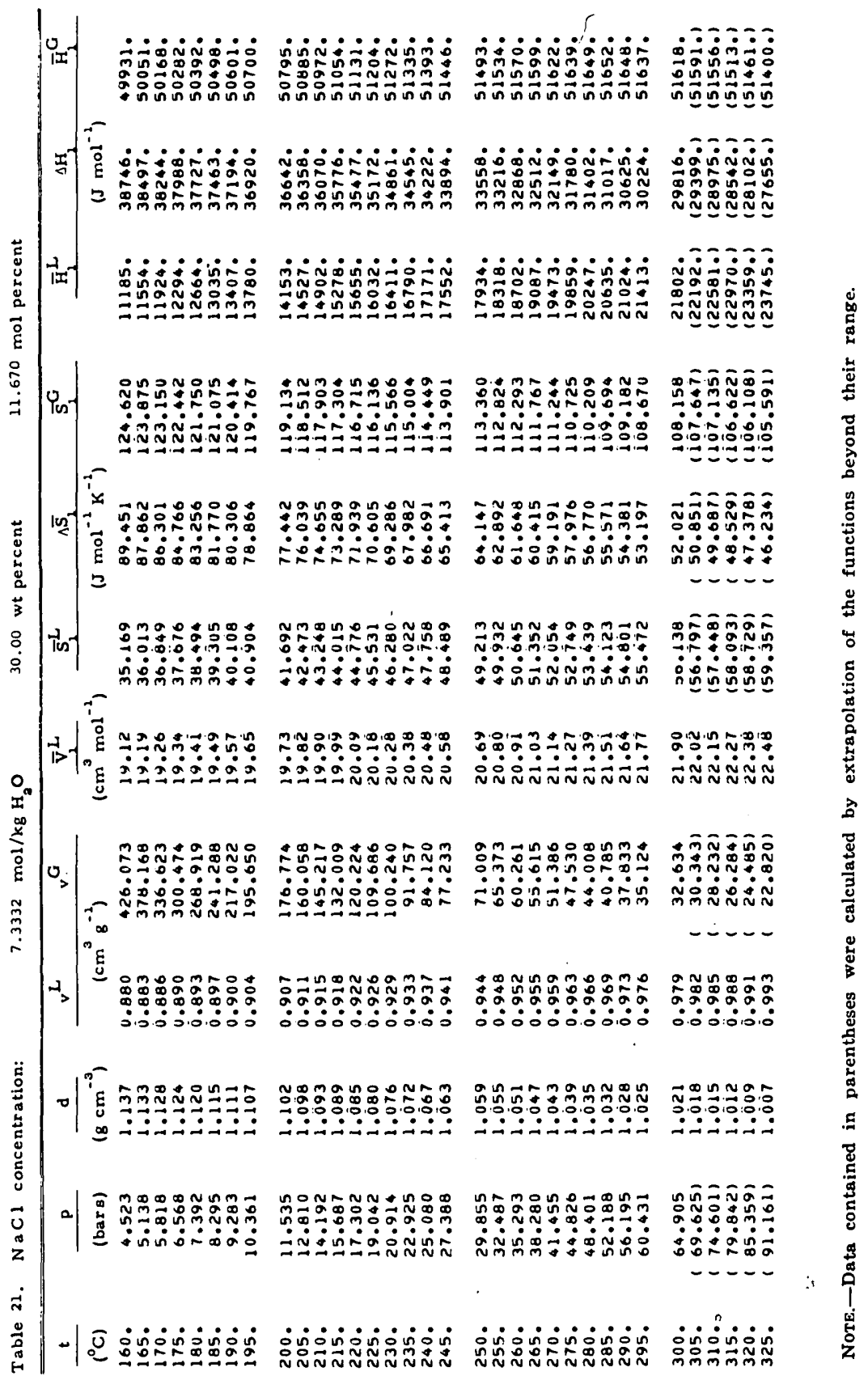




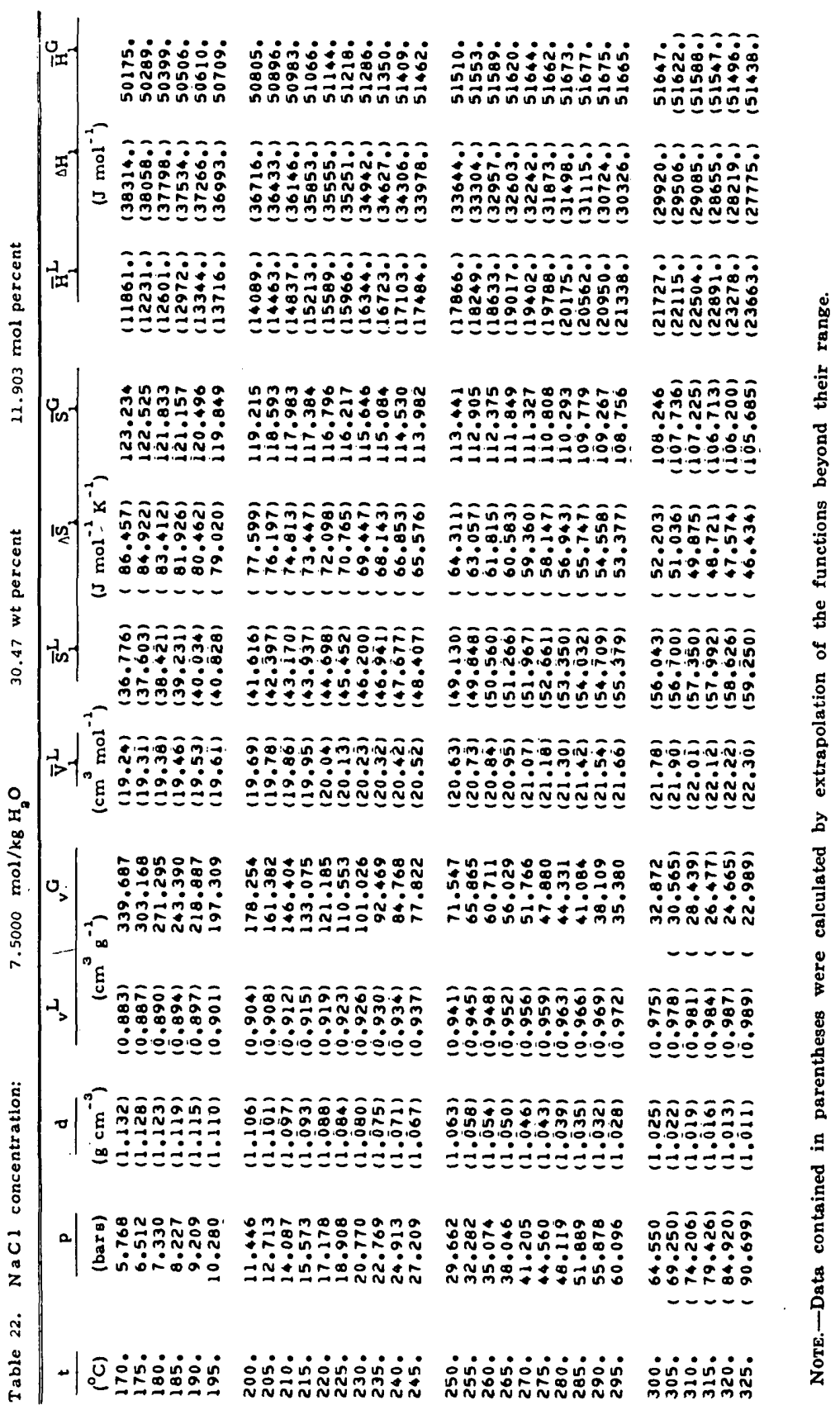




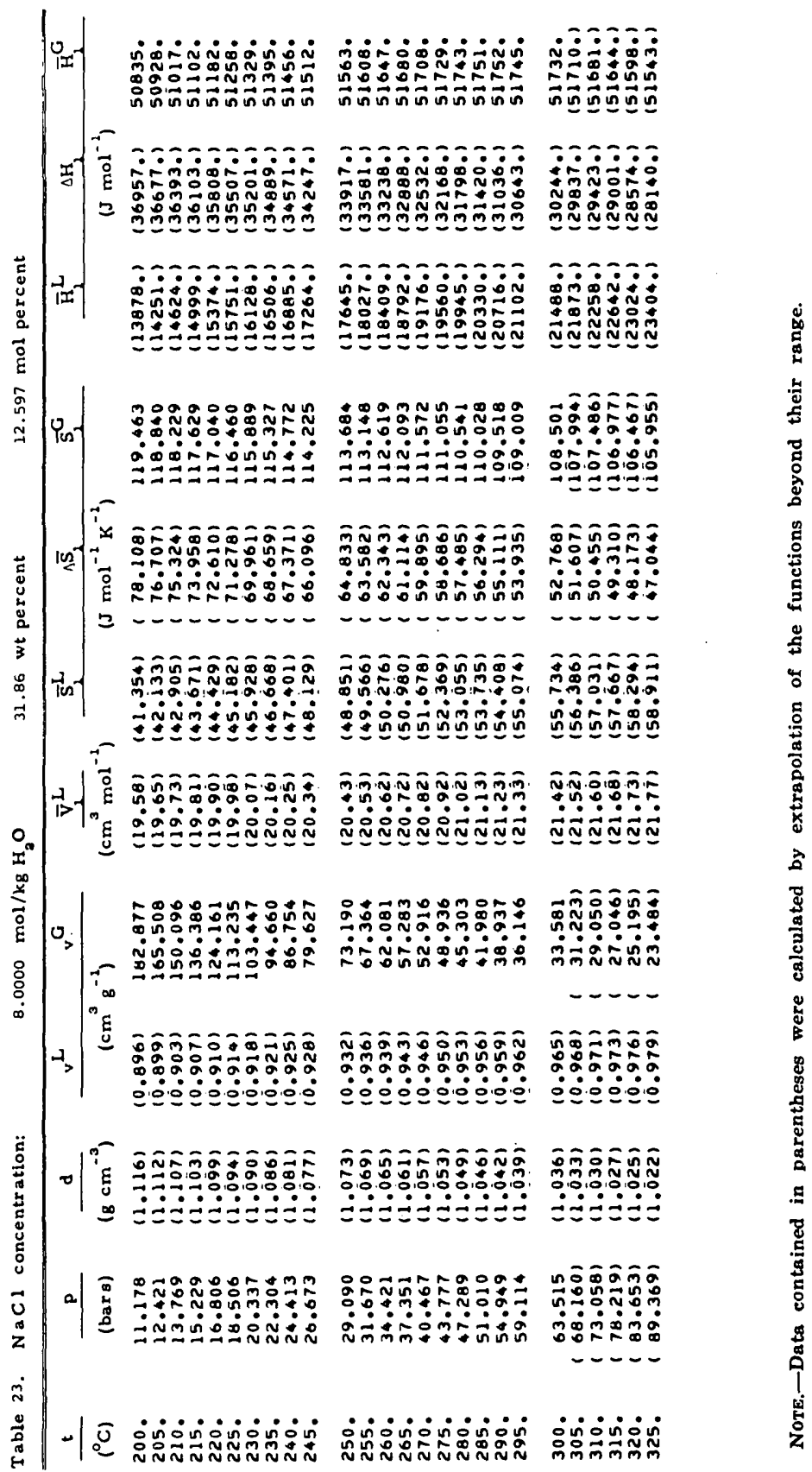




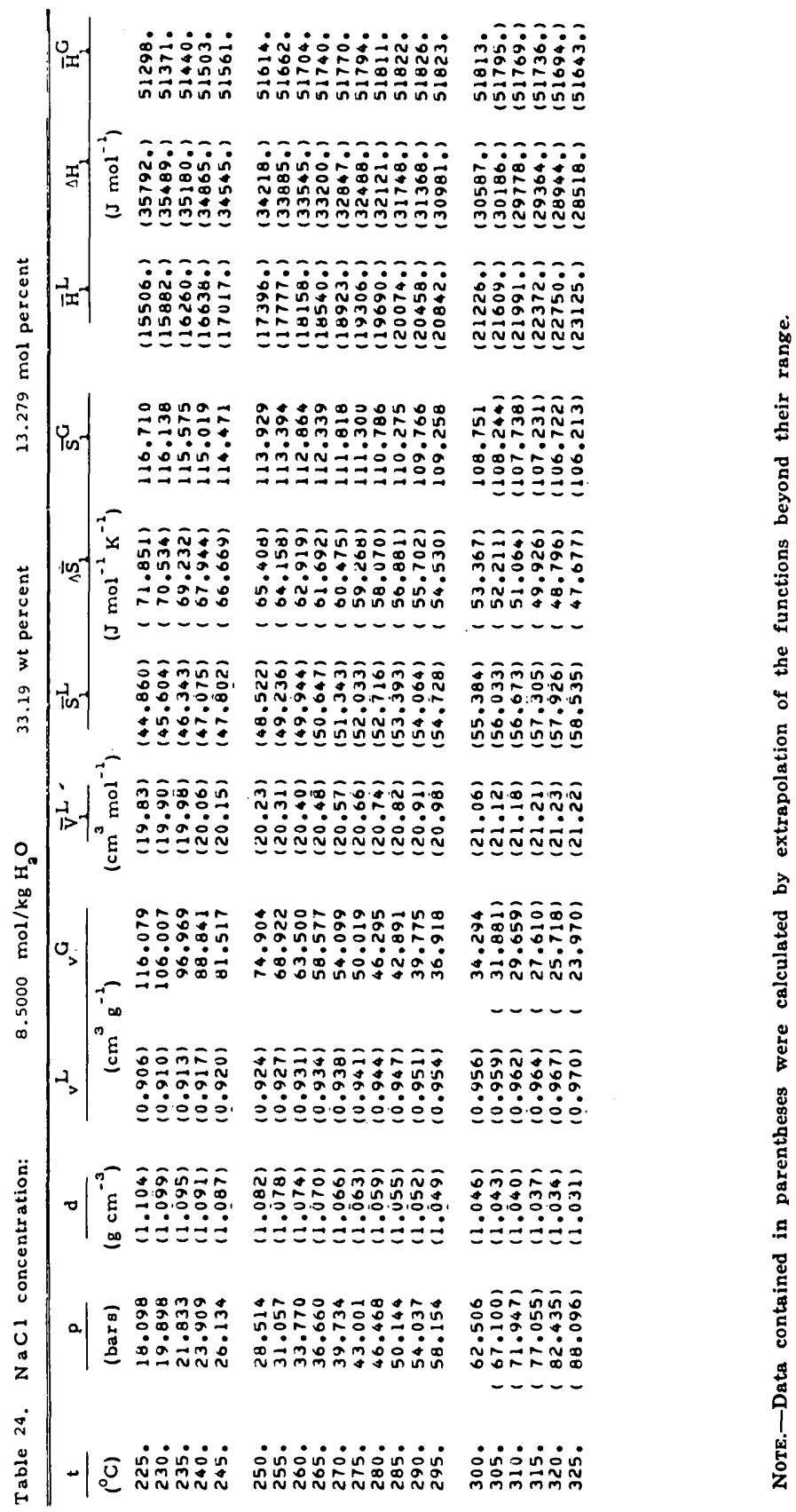




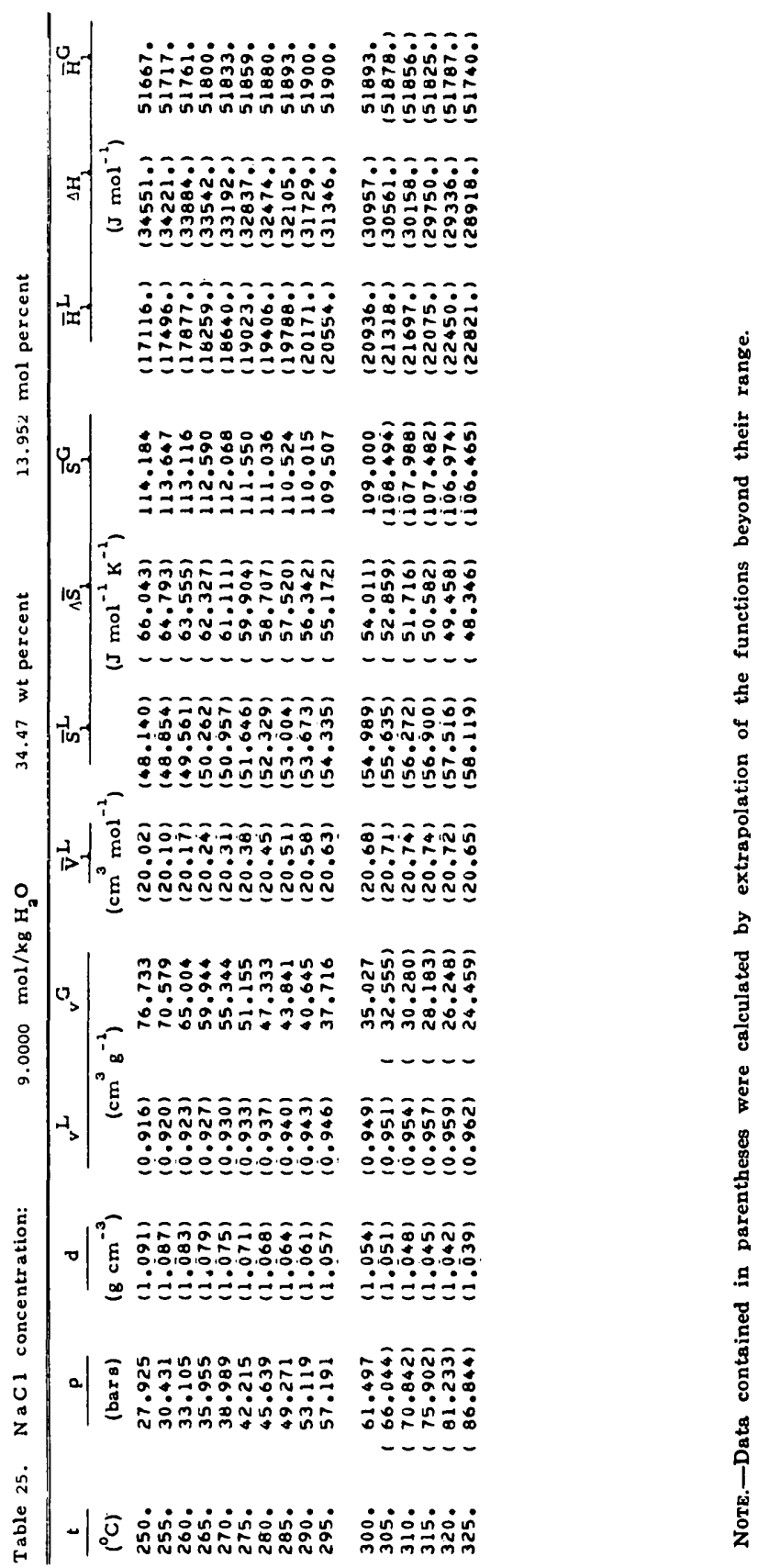




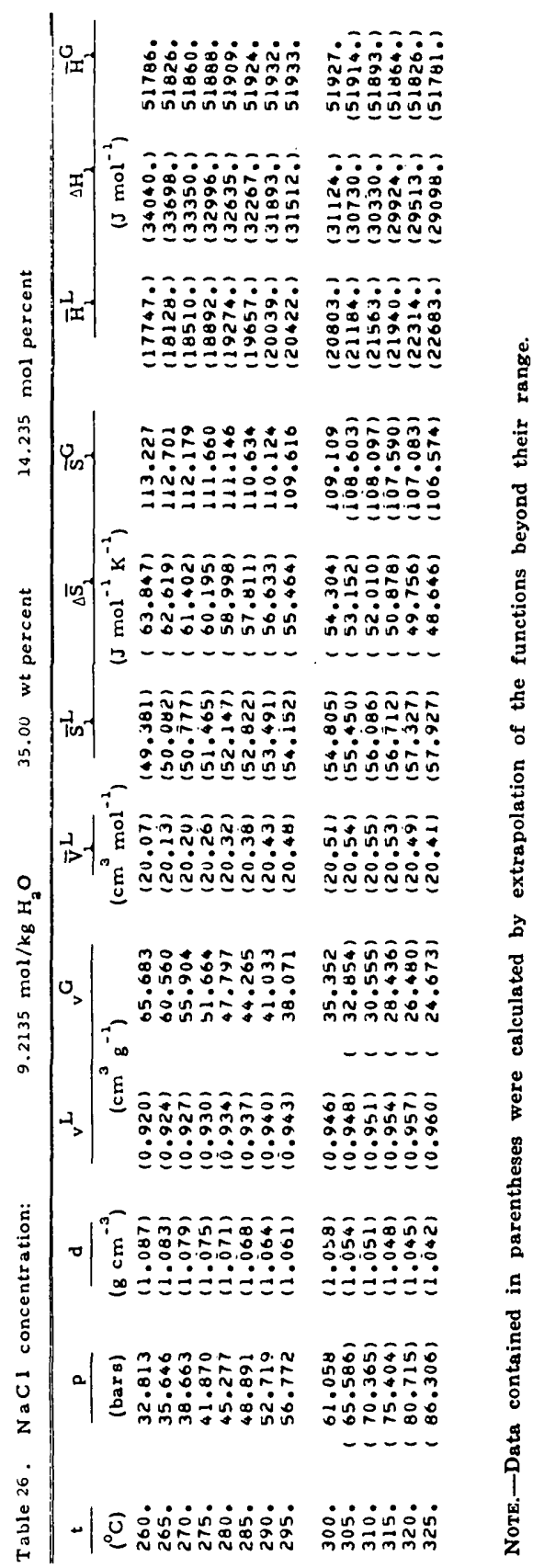




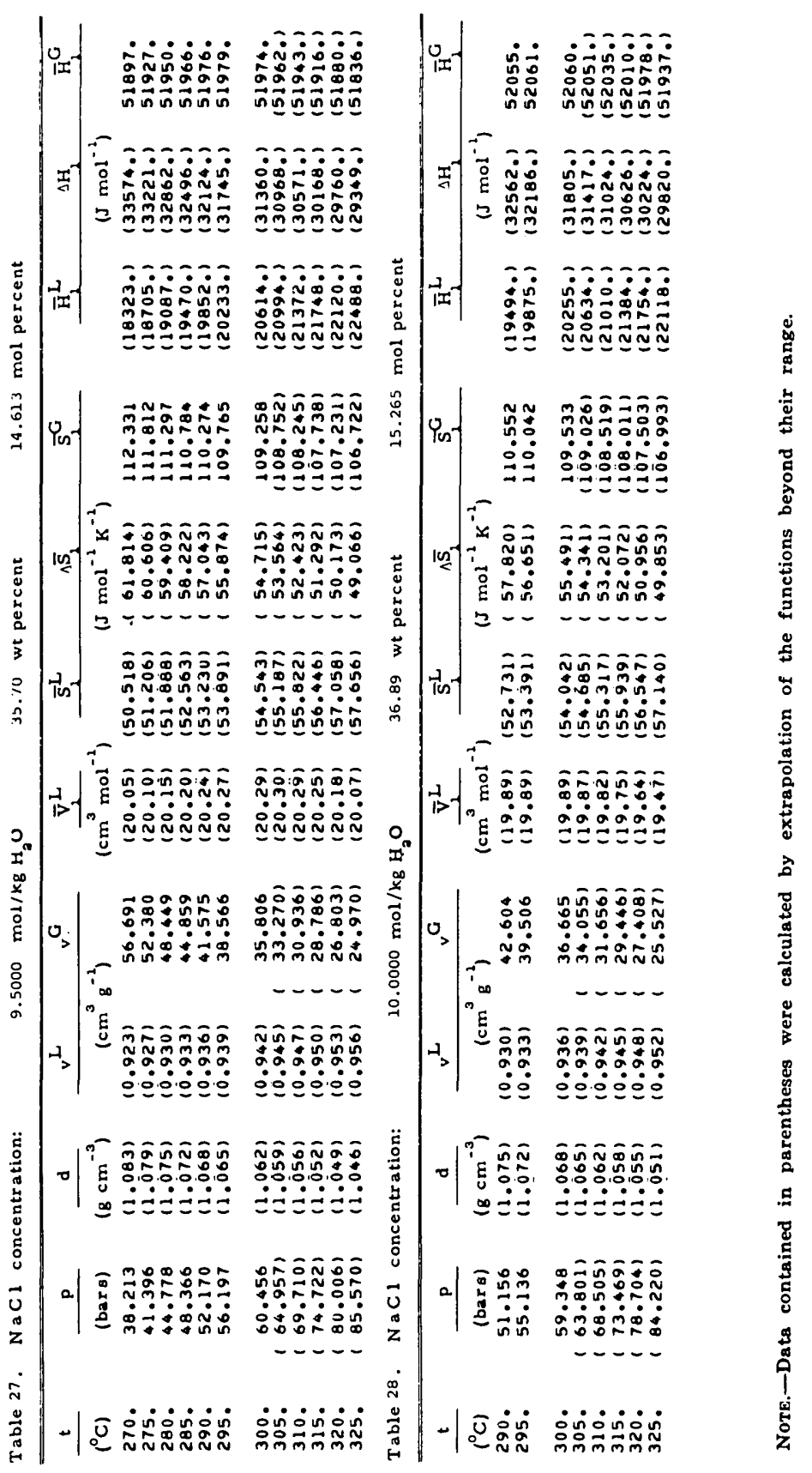




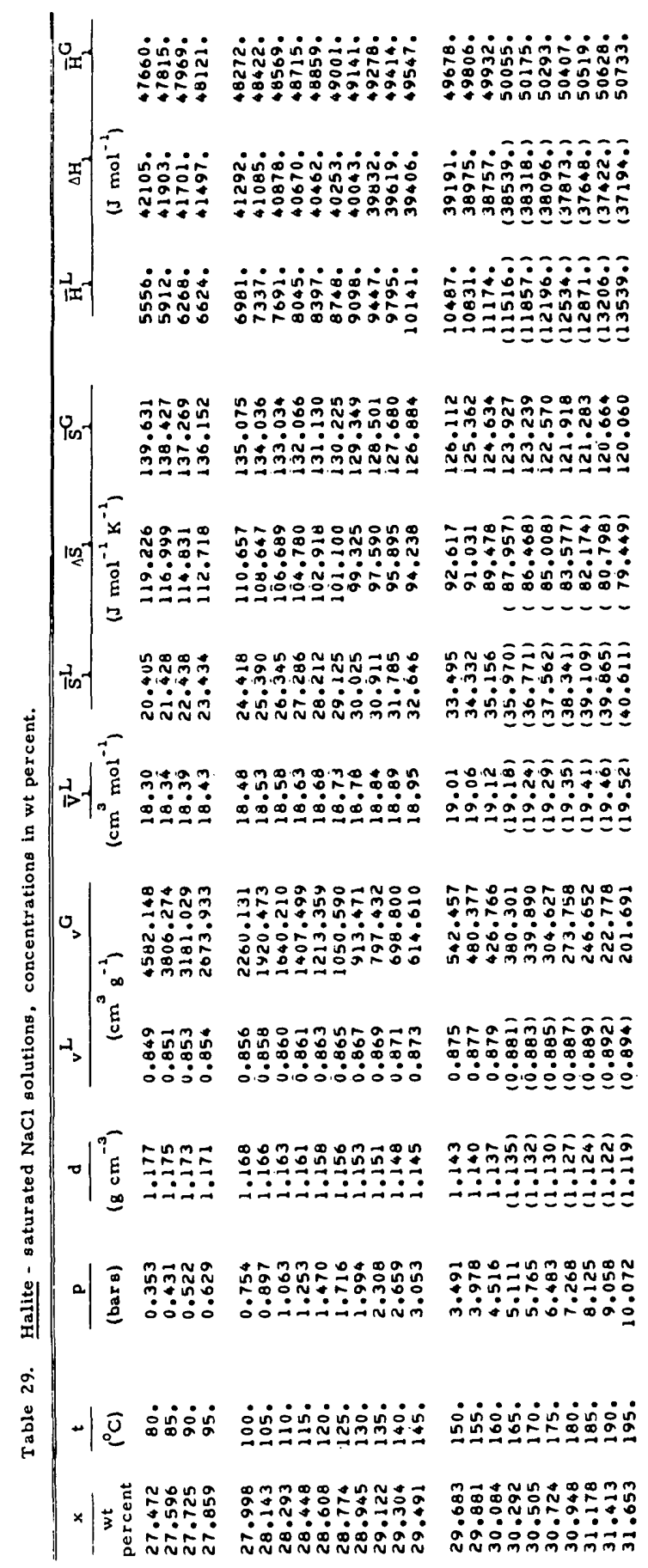



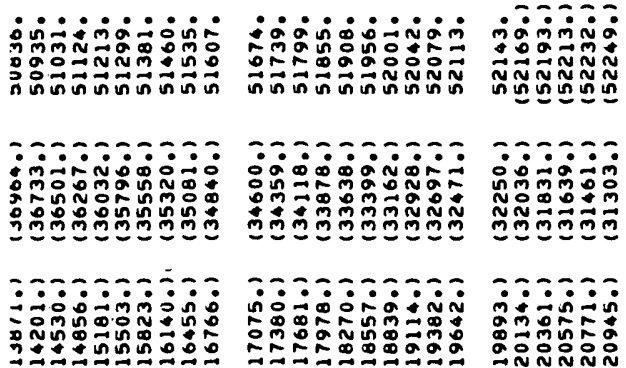

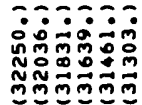
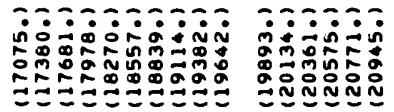

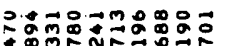

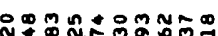

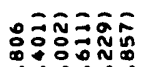

$\rightarrow 000$

N.

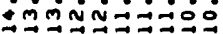

$\therefore \therefore \dot{0}$

政:

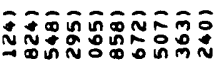

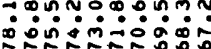

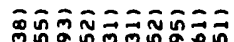

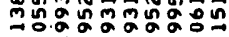

onisं

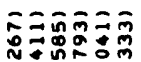

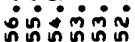

-บบบ-บ드. -บ드

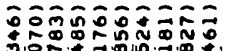

กิ๊ล์

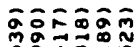

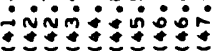

-0.ंกi

$\rightarrow \div \infty$.

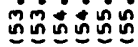

约

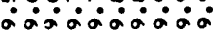

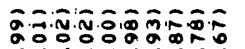

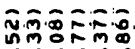

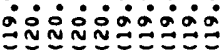

$\stackrel{0}{=} \stackrel{0}{=}$

กำกี

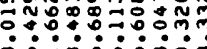

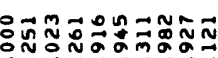

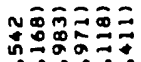

ம்:

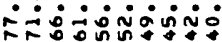

inniñ

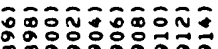 क.}

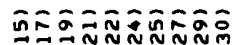

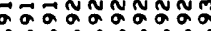
¿o.0000000

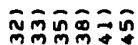

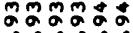
잉ㅇㅇㅇ

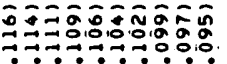

กิ์ -

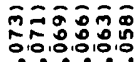
シざシさす

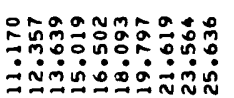

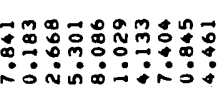

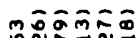

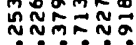
inํำ영

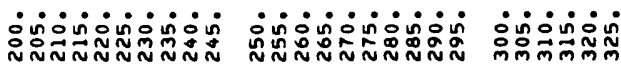

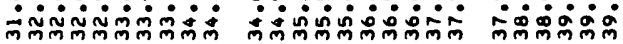




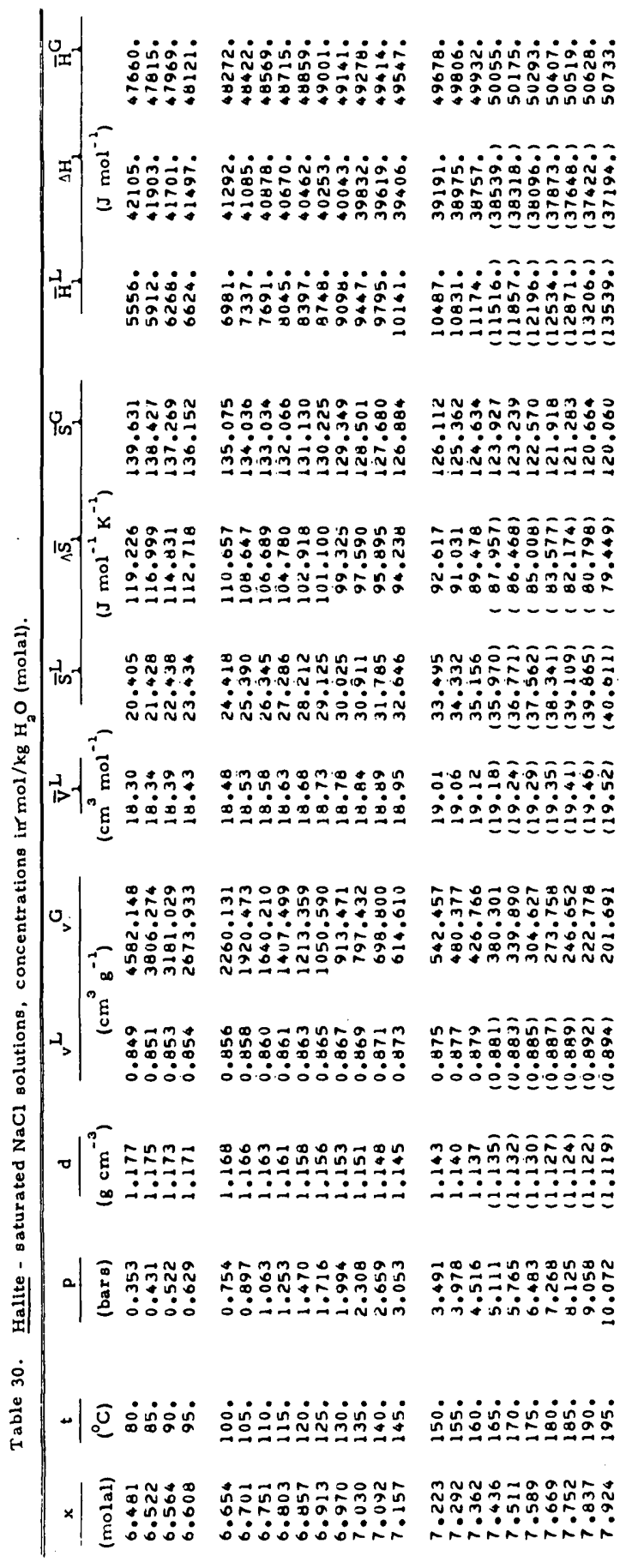




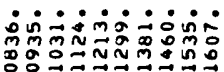

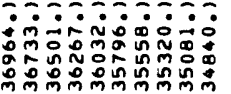

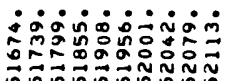

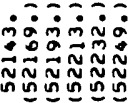

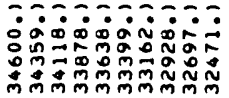

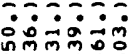

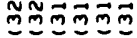

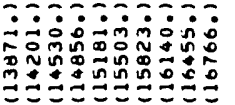

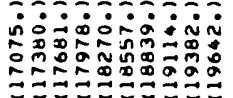

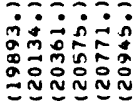

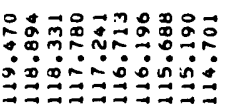

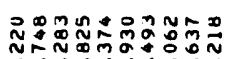

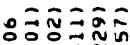

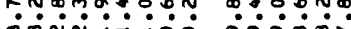

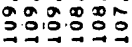

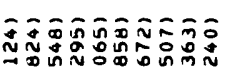

Q

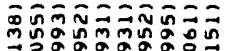

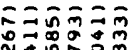

:

inंimin

ㄷ……

-

जisin

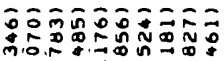

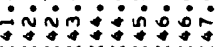

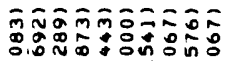

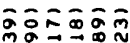

\%

$\because \dot{0}$

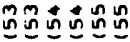

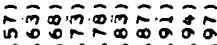

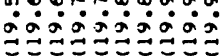

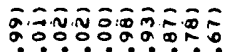

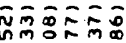

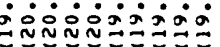

$\stackrel{0}{=} \stackrel{\infty}{=}=$

กำ

कि:

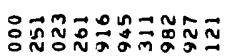

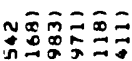

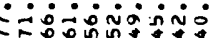

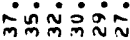

\section{ค๙}

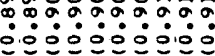

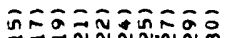

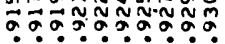

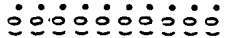

พิ๊⿳⺈冂大 요용

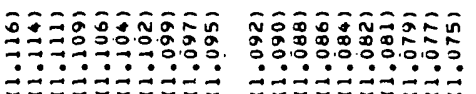

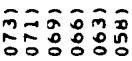

过过

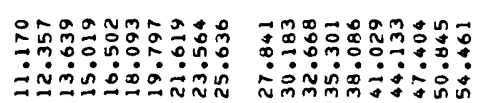

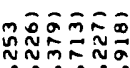

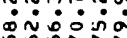

- - -

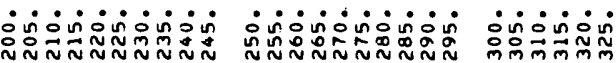

